DESCRIPTION OF WATER-SYSTEMS OPERATIONS

IN THE ARKANSAS RIVER BASIN, COLORADO

By P.0. Abbott

U.S. GEOLOGICAL SURVEY

Water-Resources Investigations Report 85-4092

Prepared in cooperation with the

SOUTHEASTERN COLORADO WATER CONSERVANCY DISTRICT and the

U.S. BUREAU OF LAND MANAGEMENT

Lakewood, Colorado

1985 
UNITED STATES DEPARTMENT OF THE INTERIOR

DONALD PAUL HODEL, Secretary

GEOLOGICAL SURVEY

Dallas L. Peck, Director

For additional information write to:

Colorado District Chief U.S. Geological Survey, MS 415 Box 25046, Denver Federal Center Lakewood, CO 80225 or Pueblo Subdistrict Chief U.S. Geological Survey

P.O. Box 1524

Pueblo, CO 81002
Copies of this report can be purchased from:

Open-File Services Section Western Distribution Branch U.S. Geological Survey, MS 306 Box 25425, Denver Federal Center Denver, CO 80225

Telephone (303) 236-7476 
Glossary- Page

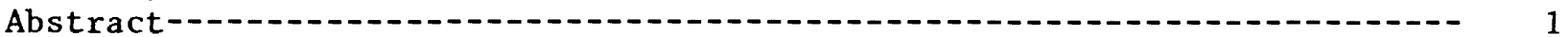

Introduction--

Location of study area-1

Purpose and scope-1 3

Acknowledgments-1- 4

Geographic setting-- 4

Population-- 4

Physiography and climate-- 4

Drainage--- 6

History of water development- 8

Water-systems operations-- 10

Municipal systems--- 11

City of Colorado Springs- 11

City of Pueblo-- 25

City of Trinidad-- 27

City of Walsenburg- 29

Irrigation systems-- 31

Arkansas River-- 32

Arkansas River tributaries-_- 36

Wet Mountain Valley-..- 36

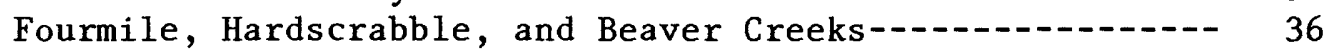

Fountain Creek-1 37

St. Charles River-1- 37

Huerfano River--_- 37

Cucharas River-_- 38

Apishapa River-1- 39

Purgatoire River-- 39

Industrial system: CF\&I Steel Corporation--- 41

Multipurpose systems--- 43

Fryingpan-Arkansas Project-_- 43

Arkansas River Compact--

Trinidad Dam and Reservoir Project-- 48

Twin Lakes Project-- 49

Use of the report-- 51

References- 51

Supplemental data-- 53

Operating plan (Pueblo Reservoir) winter water year 1982-83---.- 54

Resolution concerning an operation plan for John Martin Reservoir--- 55

\section{ILLUSTRATIONS}

Plate 1. Map of Arkansas River basin in Colorado showing location of conduits, tunnels, water districts, and general location of selected text figures where data are shown at a larger scale-1.-- in pocket

2. Map of Arkansas River basin in Colorado showing location of selected ditch headgates and reservoirs--- in pocket 
Plate 3. Diagram sketch of irrigation-ditch systems along the Arkansas River in Colorado from Canon City to the State line----- in pocket 4. Chart showing major water rights along the Arkansas River in Colorado-chet

Figures 1-4. Maps showing:

Page

1. Location of study area-n 2

2. Physiographic setting---n 5

3. Mean annual precipitation- 6

4. Mean annual runoff

5. Bar chart showing development of ground-water use------ 10

6. Map showing water-supply system for the city of Colorado Springs----.-.- 13

7. Map of the mountain collection system, for the City of Colorado Springs, showing relationship of watershed schematics, shown in figures 8 through 11- 14 8-17. Schematic diagrams showing:

8. South-slope Pikes Peak watershed, Colorado Springs mountain collection system--.---

9. North-slope Pikes Peak watershed, Colorado Springs mountain collection system-- 16

10. Northfield watershed, Colorado Springs mountain collection system--18

11. Penrose-Rosemont watershed, Colorado Springs mountain collection system--19

12. Local streamflow diversions, Colorado Springs system- 20

13. Homestake Project collection system--- 21

14. Blue River Project collection system--.-.- 23

15. Pueblo Board of Water Works system and other water development in upper Arkansas River basin, above Buena Vista-.-...- 26

16. City of Trinidad mountain collection system------- 28

17. City of Walsenburg municipal water-supply system----- 29

18. Graph showing acreage of major irrigated crops, other than

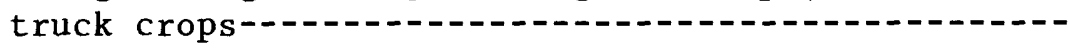

19. Graph of annual diversions from the Arkansas River between the Bessemer Ditch headgate and the Colorado-Kansas State line-- Ditch headgate and the Colorado-Kans

20-23. Schematic diagrams showing:

20. Ditch systems in the irrigated area of the Trinidad Dam and Reservoir Project-- 40

21. CF\&I Steel Corporation's near-plant water-supply system--.- 42

22. North and South Side Collection System, FryingpanArkansas Project-- 44

23. Twin Lakes Project system-- 50 


\section{O N T E N T S}

TABLES

Table 1. Developed sources of raw-water supply for the city of Colorado

Springs, 1982- 12

2. Conduits in the area- 58

3. Tunnels in the area- 59

4. Major ditches in the area- 60

5. Reservoirs in the area- 64

\section{GLOSSARY}

Water-resource terms associated with this report are defined in the GLOSSARY and are italicized. Additional terms used by irrigators, water commissioners, water managers, hydrologists, and others with water-related occupations in the Arkansas River basin in Colorado also appear in the GLOSSARY .

absolute decree (absolute water right).--A decree is conditional, as long as the facility used to store, divert, or otherwise exercise the right, is under construction, and until the time the full quantity of the decreed water has been stored or diverted. Any time after the full decree has been stored or diverted and placed to beneficial use, the holder of the decree can go to court and have the decree made absolute, in total or in increments: for example, if after the first year of storage, a reservoir had been filled to some part of the capacity of its conditional decree, an absolute decree for that quantity of storage can be obtained.

active pool.--See reservoir space allocation.

adjudication date.--The date of the court action on which the right to use of the water is legally acknowledged. Three dates are important in the determination of basin priority of a water right: (1) The appropriation date when the initial work toward utilizing the water was begun; (2) the adjudication date, when the decree was granted by the court; and (3) the date of the previous adjudication. Consideration of the last date is necessary, as all rights must have an equal opportunity to adjudicate; in the past, courts in some areas of the Arkansas River basin adjudicated at different times from those in other areas of the basin. This is no longer a problem, as water rights are now adjudicated in one Water Court.

alternate point of diversion.--A change in decree must be obtained to divert from a point other than that described in the decree. In recent years, wells located in the alluvial aquifer commonly have been made alternate points of diversion for surface-water rights.

appropriation.--"..the application of a specified part of the waters of the State to a beneficial use pursuant to the procedures described by law..." (Radosevich and others, 1975). The term fully appropriated means that there are enough adjudicated water rights along the particular reach of stream to account for all water in the stream, under normal conditions. 
called out.--The demand that a junior right cease diversion, in order that sufficient water be available to the senior right.

canal.--An artificial waterway for the delivery of water; synonymous with "ditch" in the Arkansas River basin.

change in water right.--"... a change in the type, place, or time of use; a change in the point of diversion; a change from a fixed point of diversion to alternate or supplemental point of diversion; a change in means of diversion; a change in the place of storage; a change from direct application to storage and subsequent application; a change from storage and subsequent application to direct application; a change from a fixed place of storage to alternate places of storage; a change from alternate places of storage to a fixed place of storage; or any combination of such changes. The term "change of water right" includes changes of conditional water rights as well as changes of (absolute) water rights..." (Radosevich and others, 1975).

conditional water right (conditional decree).--"...a right to perfect a water right with a certain priority upon the completion with reasonable diligence of the appropriation upon with such water right is to be based..."(Radosevich and others, 1975)--see absolute decree.

conduit.--As used in this report, a closed duct or pipe for transporting water, a pipeline, or aqueduct.

conservation pool.--See reservoir-space allocation.

dead-storage pool.--See reservoir-space allocation.

direct-flow water right.--See water right. A direct-flow water right requires that the water be put to immediate beneficial use, as opposed to a storage right, which allows storage of a set volume of water for later use. Directflow water rights are described by a rate of diversion, such as cubic feet per second, gallons per minute, or (rarely) miners' inches. (The latter two have been converted to cubic feet per second in recent tabulations.)

ditch.--Used here synonymously with "canal."

diversion or divert.--"...removing water from its natural course or location, or controlling water in its natural course or location, by means of a ditch, canal, flume, reservoir, bypass, pipeline, conduit, well, pump, or other structure device..." (Radosevich and others, 1975).

Division Engineer.--The State of Colorado is divided into seven water divisions under the State Engineer. Each water division is administered by a Division Engineer, who is responsible for administering the water rights in the division. The division is further divided into water districts, which are administered by water commissioners directly responsible to the Division Engineer. The Arkansas River basin constitutes Division 2.

due diligence.--The holder of a conditional water right must prove to the water court once every 4 years that he or she is working with reasonable diligence toward the appropriation of that right; for example, he or she is working toward the construction of the system, reservoir, or canal, required to regulate the water. 
economic life of a reservoir.--In project planning, a feasibility study is made for any proposed reservoir. As a part of this study, consideration is given to the decrease of storage space within the reservoir by the deposition of sediment. The determination must be made that, during some period, the economic life of the reservoir, the economic benefits derived from storage in the reservoir, or flood protection by the reservoir are greater than the cost of constructing and maintaining the reservoir. The "useful life" of the reservoir usually extends far past the economic life.

evaporation charge.--If evaporation from the water surface of an on-channel reservoir were not accounted for, would constitute a loss to the stream on which the reservoir is built. To offset this loss of public waters, the daily rate of evaporation is measured (usually by a class A pan): a pan factor is applied to convert pan evaporation to lake-surface evaporation, and this rate is applied to that day's lake-surface area to compute the day's evaporation. Allowance is made for the evaporation that would have taken place had the lake not been present, and the resulting volume is released to the river from the storage account occupying the lake. The evaporation charge is administered in the Arkansas River basin by the Division Engineer, Colorado Water Division 2.

exchange.--A water exchange is possible by diverting water at one point in the river system, and replacing a like quantity of water from storage or transmountain diversions at another point in the system. To be legal, no party can be injured by the diversion. For example, an exchange is made to enable use of Lake Meredith water by irrigators who have rights to water diverted by the Colorado Canal. As Lake Meredith is downgrade from most land irrigated by water diverted by the canal, water is diverted from the river at the Colorado Canal headgate, and replaced, made whole, from storage through the Meredith Outlet Canal, which enters the river a few miles downstream from the headgate. Sufficent flow must be left in the river downstream from the Colorado Canal headgate to satisfy any senior rights between the headgate and the outlet canal. Exchanges can be made upstream or downstream from the point of use. River-transit losses are accounted for in the exchange.

flood-control pool.--See reservoir-space allocation.

flood right.--Said of a very junior right, one that is in priority only during flooding or during a free river.

free river.--A local term used to describe a condition where the flow of the river is sufficient to satisfy all vested rights, and diversions from the river can be made without possibility of injury to any senior right. In the Arkansas River basin in Colorado, this condition seldom exists, except during flooding.

futile call.--If, in the opinion of the Division Engineer, there is no possibility that water called out by a downstream senior right will reach the headgate of that right, the Division Engineer has the discretion (on the basis of paragraph 37-92-502(2) of the Water Right Determination and Administrtion Act of 1969) of not honoring the call and allowing the upstream junior right to continue diversion. 
green water.--A local term for water released from a major reservoir, referring to the absence of sediment in the water. Also, reservoir water with a lot of algae.

headgate.--The point on the stream at which water is diverted. A headgate can be a simple board structure on the stream bank, or a complex hydraulic structure consisting of radial gates and many other devices.

in priority.--See priority system.

inviolate space.--Inviolate reservoir storage space refers to space allocated to a single purpose, usually flood control, which cannot be infringed on for other uses, not even sediment accumulation. To keep the space inviolate, the elevation of the top and bottom of the various pools must be redefined periodically. For this purpose, reservoir-sedimentation surveys are conducted after set periods of time, and after major floods.

irrigation pool.--See reservoir-space allocation.

joint-use pool.--See reservoir-space allocation.

junior right.--A relative term describing a water right with a priority less than that of a "senior right." In general use in the Arkansas River basin, junior rights refer to those water rights seldom in priority; senior rights refer to those water rights usually in priority.

made whole.--To leave the river in the condition it would have been had the exchange, reservoir release, or other action not taken place. (Robert Jesse, Colorado Water Division 2 Engineer, written commun., August 23, 1984.)

native water.--As used in this report, water naturally occurring in the basin in which it is found; not imported from outside the basin.

off-stream reservoir (off-channel reservoir).--A surface-water storage reservoir located outside the channel of the stream that constitutes the principal source of the water stored in the reservoir. Off-stream storage is supplied by a ditch or conduit, with the headgate located on a stream other than that in which the reservoir is situated. Those off-stream reservoirs located in the channel of a tributary might store minor quantities of the waters of that tributary as well. Like other reservoirs in Colorado, a storage right is required that describes the source, quantity, use, and priority of all water stored.

on-stream reservoir (on-channel reservoir).--An on-stream reservoir derives most of the water stored from the stream on which the reservoir is located. A storage right is required.

penciled out.--A local term used to describe the transfer of water from the "compact pool" (conservation pool) to the "agreement pool" (accounts) in John Martin Reservoir. See Arkansas River Compact section.

penstock.--The conduit that conveys water under pressure to the turbines of a hydroelectric powerplant. 
plan for augmentation.--"...a detailed program to increase the supply of water available for beneficial use in a division or part thereof by the development of new or alternate means or points of diversion; by pooling of water resources; by water-exchange projects, by providing substitute supplies of water; by the development of new sources of water; or by any other appropriate means. "Plan for Augmentation" does not include the salvage of tributary waters by the eradication of phreatophytes, nor does it include the use of tributary water collected from land surfaces that have been made impermeable, thereby increasing the runoff, but not adding to the supply of tributary water..." (Radosevich and others, 1975).

power pool.--See reservoir-space allocation.

previous adjudication date.--A date listed in the tabulation of all water rights that is significant, in that, regardless of the priority date assigned, all rights adjudicated on a given date are junior to all rights adjudicated at an earlier date. The opportunity to adjudicate is taken into consideration in establishing basin-wide priorities.

priority system.--In the United States, two major types of water-1aw doctrines occur. The riparian doctrine holds that waters are appurtenant to the land through which they flow. The appropriation doctrine holds that the waters within a State are the property of the public, with a vested right to the use of the appropriation: the first in time to use the water is first in right. It is the establishment of the order of the first in time being first in right that has been designated priority, and the system under which these water rights are administered has been referred to as the "priority system."

raw water.--In this report, raw water refers to untreated municipal or industrial water supplies.

recreation pool.--See reservoir-space allocation.

replacement storage.--A feature of transmountain diversions in Colorado. The purpose of replacement storage is to store water during that part of the year when runoff is at a peak and all rights are being satisfied downstream in the basin, and to hold these waters for later release. Later release comes during that part of the year when the snowmelt peak has ended, and runoff in the basin is at a much slower rate. Water upstream from the transmountaindiversion system in excess of minimum fish-flow requirement might still be diverted, regardless of the date of the call on the river from which the diversions are made, provided a quantity equal to that diverted from the basin be released from replacement storage to meet the demands of senior rights downstream.

reservoir-space allocation.--Federally constructed reservoirs serve multiple purposes. Space in these reservoirs is allocated to the various purposes. This space, called pools, usually is defined by the bottom and the top elevation of the pool. Sediment accumulation necessitates periodic redefinition of these top and bottom elevations. Terminology will vary slightly with the agency operating the reservoir, and with the chief purpose for which the reservoir was constructed. Space-allocation terms used in reservoirs located 
in the Arkansas River basin in Colorado include: The minimum pool or permanent pool is the pool below which water is not withdrawn. It can include a dead-storage pool below the elevation of the outlet works, or a recreation pool, that is held at a certain level to provide scenic, fishing, boating, or other recreational opportunities. The minimum pool might be held at a certain level to enable delivery of water to a given required elevation. Above the permanent pool, is the active pool, where water can be regulated. The conservation pool is used to store water for later use. If the use is for irrigation, the conservation pool can be considered the irrigation pool; under other uses, it might be the power pool or the municipal pool. The flood-control pool (flood pool) is considered inviolate space, and it cannot be decreased during the economic life of the reservoir by sedimentation. Surcharge is water temporarily stored above the lip of the uncontrolled spillway, which helps decrease the peak of very large floods. Sediment pool is the space reserved for accumulation of sediment throughout the economic life of the reservoir, (usually 75 to 100 years). Because water surfaces of most onstream reservoirs are constantly changing, the sediment is not deposited below a specific elevation; therefore, the top and bottom of the sediment pool are not defined by $\epsilon$ levation. The joint-use pool is a pool used for more than one purpose. For example, the joint-use pool in Trinidad Reservoir refers to the 39,000 acre-foot sediment pool, which, before it is occupied by sediment deposition, will be used to regulate irrigation supplies. In Pueblo Reservoir, the joint-use pool refers to 66,000 acre-feet, which, between the dates of April 15 and October 31 , is inviolate flood space; during the rest of the year, this space can be used to regulate irrigation supplies. Reservoir-space allocation is revised with sediment accumulation; thus, one might encounter such terms as initial, 50-year, and 100-year allocations.

riparian doctrine.--A form of water law that gives the owners of the land adjacent to the water course equal rights to the use of the water.

river call.--Under normal flow conditions, the Arkansas River call date is simply the decree date of the most junior diversion, drawing a part of its decreed rights from the Arkansas River. The date is determined by the Division Engineer in conjunction with Water Commissioners of water districts concerned, and affects diversions in Water Districts $10,11,12,13,14,15$, 17 and 67. It is based on flows at the Portland, Pueblo, Avondale, and La Junta streamflow-gaging stations, and the decreed diversions in Water Districts 14 and 17. Advanced notice of increasing and decreasing river flow is provided by the Granite and Wellsville streamflow-gaging stations. Under certain conditions, two distinct call dates may exist: one for the river upstream from Pueblo, and a second for the river downstream from Pueblo. The date downstream will be later, because of substantial inflow or return flow to the river. The call date on tributaries is determined by both the river call and the flow in the specific tributary. For example, although the Arkansas River call may be 1882 , an 1879 right on a certain tributary might not be able to divert, because all flow of that tributary is going to satisfy a 1875 right from the same stream. (Jim Kasic, Assistant Division Engineer, Division 2, oral commun., 1983.)

sediment pool.--See reservoir-space allocation. 
senior right.--A relative term referring to a right with an earlier priority. See "junior right."

shrink.--A local term used to describe the decrease of an entity's water supply by any one of a number of causes. It has been used in reference to: (1) The transportation loss charged in routing a reservoir release down a river channel; (2) the pro-rata share from the participants of the Pueblo Reservoir Winter Water Program (see discussion under Fryingpan-Arkansas Project; to provide the agreed share to an entity not receiving a full share; and (3) the decrease of reservoir-storage accounts by evaporation.

slick water.--A local term used to describe high flow from the Apishapa River into the Arkansas River. Because of the large concentration of sediment in Apishapa flood flows, the water is undesirable for irrigation, and, when possible, is not diverted.

sluice.--As used most commonly in the Arkansas River valley in Colorado, this local term refers to the act of washing sand and other sediments from canals back into the stream from which they were diverted. Most canals are equipped with one or more sluice gates along their length, one almost always just downditch from the headgate, and up ditch from the measuring section.

sluice box.--In placer mining, a long inclined trough paved with riffles for catching gold from water-borne gravel washed through the passage.

storage.--"..the impoundment, possession, and control of water by means of a dam..." (Radosevich and others, 1975). To retain possession of stored waters requires a storage right (storage decree).

storage right.--See water right. A storage right allows the holder to store a given volume of water each year for beneficial use later in the season or in following seasons.

surcharge.--See reservoir-storage allocation.

tailwater.--Excess surface water draining from an irriated field or returning to natural channels from the downgradient end of an irrigation ditch. It also is the water in a channel immediately downstream from a dam, mill, or powerplant.

transit loss.--Colorado water law allows the owner of a reservoir to use a natural stream to convey stored water to the place of use, provided that allowance is made for losses that occur while the water is in the natural stream. The State Engineer has the responsibility of determining these losses (Luckey and Livingston, 1975).

transmountain diversions.--The importation of water originating in one river basin from that basin into another river basin. The diversion is by means of a ditch, canal, or conduit through a topographic saddle in the divide between the basins, or by means of a tunnel through the basin divide. A water right is required in the basin from which the diversion is made, and a record of imports is made at the outlet end of the conveyance structure in the receiving basin. 
trap efficiency (reservoir).--The percentage of the sediment load that is retained in a reservoir to total sediment load flowing into the reservoir. Trap efficiency depends on reservoir size, on reservoir shape, on the nature of the sediment entering the reservoir, on reservoir operation, and on the ratio of storage capacity to inflow volume.

useful life of a reservoir.--See economic life of a reservoir.

waste.--As used in the Arkansas River basin and in this report, waste is a local term that refers to water turned back into the source stream or lake unused. Waste gates are structures located along canals to enable release to the river, usually for the purpose of sluicing sand from the canal. It has no reference to nonbeneficial use of water. Used water, as in a manufacturing process, also is termed waste.

water right.--"...a right to use in accordance with its priority a certain part of the waters of the State by reason of appropriation of the same..." (Radosevich and others, 1975).

\section{METRIC CONVERSION}

The inch-pound units used in this report may be converted to International System of Units (SI) by the following conversion factors:

$\begin{array}{lcl}\text { Multiply } & \text { By } & \text { To obtain } \\ \text { acre } & 0.4047 & \text { hectare } \\ \text { acre-foot } & 1,233 & \text { cubic meter } \\ \text { cubic foot per second } & 0.02832 & \text { cubic meter per second } \\ \text { foot } & 0.3048 & \text { meter } \\ \text { inch } & 25.40 & \text { millimeter } \\ \text { mile } & 1.609 & \text { kilometer } \\ \text { square mile } & 2.590 & \text { square kilometer } \\ \text { million gallons per day } & 4.381 \times 10^{-2} & \text { cubic meters per second }\end{array}$




\title{
DESCRIPTION OF WATER-SYSTEMS OPERATIONS IN THE ARKANSAS RIVER BASIN, COLORADO
}

By P.0. Abbott

\begin{abstract}
To facilitate a current (1985) project modeling the hydrology of the Arkansas River basin in Colorado, a description of the regulation of water in the basin is necessary. The geographic and climatic setting of the Arkansas River basin that necessitates the use, reuse, importation, and storage of water are discussed. The history of water-resource development in the basin, leading to the present complex of water systems, also is discussed. Municipal, irrigation, industrial, and multipurpose water systems are described. System descriptions are illustrated with schematic line drawings, and supplemented with physical data tables for the lakes, tunnels, conduits, and canals comprising the various systems. Copies of criteria, under which certain of the water systems operate, are included.
\end{abstract}

\section{INTRODUCTION}

The water in the Arkansas River basin is a valuable resource that transforms fertile but dry lands into productive agricultural areas. Historically, in this area, man used and reused available water, stored water in times of more abundant supply for use in times of low streamflow, imported water from nearby drainage basins where supply was greater and demand less, and utilized the ground-water aquifer in the valley alluvium. A comprehensive surfacewater/ground-water model of the Arkansas River basin in Colorado currently (1985) is being developed by the U.S. Geological Survey. To design this model, the description of water-systems operations in the basin is essential. The operations of the more complex systems in the valley are described here, including municipal systems, irrigation systems, an industrial system, and multipurpose systems.

\section{Location of Study Area}

The Arkansas River basin in Colorado generally is located between $37^{\circ}$ and $39^{\circ}$ latitude and $102^{\circ}$ and $106^{\circ}$ longitude, and contains approximately the southeast one-quarter of the State (fig. 1). The drainage area, not including the Cimarron River watershed, is 25,400 square miles. The Cimarron River watershed, located in the extreme southeast corner of the State, is a part of the Arkansas River basin not considered in this report. Locations mentioned in the text and not found in other figures can be found on plate 1 or plate 2 in the pocket. 


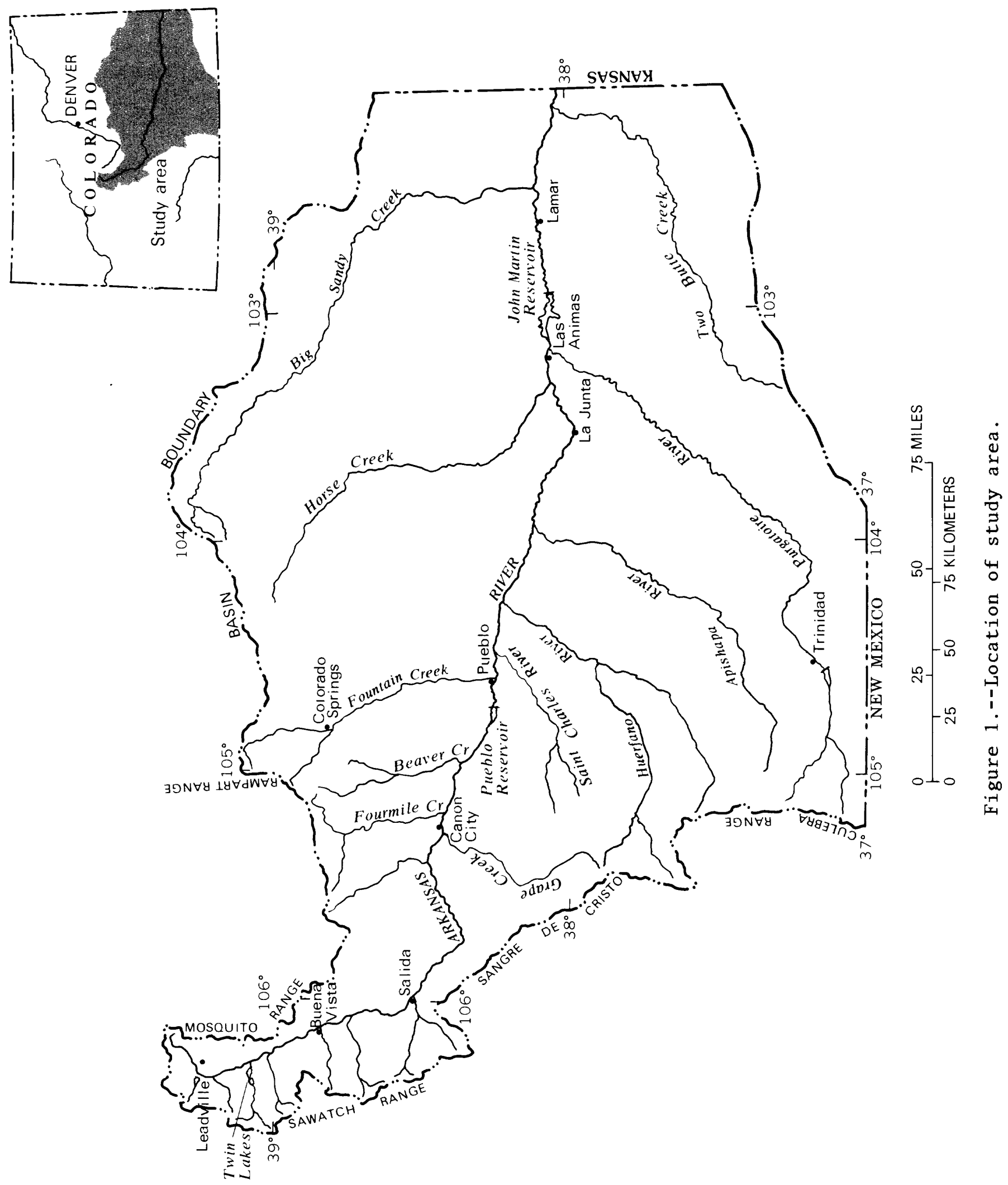


The terminology used in this report currently (1985) is used among irrigators, water commissioners, water managers, hydrologists, hydrographers, water-resource technicians, and others with water-related occupations in the Arkansas River basin of Colorado. Because some of these terms are not widely used in other parts of the Nation, a glossary has been provided.

\section{Purpose and Scope}

In a semiarid region like the Arkansas River basin of Colorado, water that originates in the basin, and water that is imported from outside the basin, are used and reused many times. The U.S. Geological Survey currently (1985) is developing a comprehensive surface- and ground-water model of the Arkansas River drainage basin in Colorado. To accomplish this task, a description of the water-systems operations in the basin is essential. This report describes the system of surface-water diversions, the transmountain imports and exports, the regulation of flows by on-stream and off-stream reservoirs, and the various water exchanges that are used in the Arkansas River as of 1983.

Administration of water in Colorado is the responsibility of the Colorado State Engineer; administration of Arkansas River water is delegated to the Division Engineer, Colorado Water Division 2, who is assisted by Water Commissioners in each of the 13 local water districts (pl. 1). Colorado Water Division 2 covers the entire Arkansas River basin in Colorado. Regulation of water is provided by the State Constitution and laws and statutes of the State, and by their interpretation in numerous court decisions. This report is not concerned with the legal aspects of systems operation, only the result of that legal regulation. The operations of the larger systems, those in which sizable quantities of water are involved, are described, and the more complex operations are described in detail, regardless of their water quantities. For example, an irrigation ditch with an early direct-flow water right that diverts water from a river and transports it directly by gravity in a canal to nearby farm plots for irrigation, is a simple operation, regardless of the quantity of water involved. If, however, the water was diverted from the river at the canal headgate, at a time when the canal's direct flow right was not in priority, and the river then was made whole at some point downstream by release of stored water from the diverter's storage right, then that complex system may be given a more thorough description in this paper, regardless of the volume of water involved.

Recently, a profusion of so-called "plans for augmentation" has developed. Although these plans are sufficiently complex to warrant detailed description, most of them involve only minor quantities of water; therefore, their description is not included in this paper.

In describing the water systems in operation in the Arkansas River basin, constant reference is made to canals, ditches, tunnels, conduits, dams, and reservoirs, and some statistical description of these various features is given. A more detailed description of each of these features (location, size, purpose, owner, and so forth) is provided in the Supplemental Data section at the end of the report. 


\section{Acknowledgments}

A report of this nature requires information and cooperation from many people. The author would like especially to thank the following: Ralph Adkins and Joseph Mahaney, CF\&I Steel Corporation; Roger L. O'Hara, Pueblo Board of Water Works; James Fernandez, City of Trinidad Department of Utilities; Edward Martinez, Colorado Springs Department of Utilities; Carmel A. Garlutzo and Patricia Hines, Purgatoire River Water Conservancy District; Charles L. (Tommy) Thomson, Southeastern Colorado Water Conservancy District; Thomas A. Gibbens, Fryingpan-Arkansas Project; Jack McCullough, Twin Lakes Project; and Raymond Harriman, Walsenburg Water Department. Thanks also go to Robert Jesse, Division Engineer Colorado Water Division 2, and to James F. Kasic and Kenneth Cooper, Assistant Division Engineers, William Howland, Engineering Technician II, and Thomas C. Simpson, Hydrographer. The following Water Commissioners were extremely helpful: Robert Ermel, Water District 10; Bruce Smith, Water District 11; George Wichmann, Water District 12; Donald K. Stuart, Water District 13; George Ridenour, Water Districts 14 and 15; Robert Brgoch, Water District 16; Donald L. Taylor, Water District 17; Leonard Trujillo, Water District 18; Henry D. Marquez, Water District 19; Lane Hackett, Water District 67; and Augustine Garcia (deceased), Water District 79. The author is solely responsible for any errors found in this report.

\section{GEOGRAPHIC SETTING}

\section{Population}

Population in the area was determined by the 1980 census (U.S. Bureau of the Census, 1980) to be 567,000, or almost 20 percent of the total population of Colorado. Most of the population is located along the base of the mountains in two counties: E1 Paso County (55 percent), and Pueblo County (22 percent). Much of the remainder of the population is concentrated along the Arkansas River.

\section{Physiography and Climate}

The physiographic setting of the study area has been described by Fenneman (1931). The western part of the basin, approximately west of the $105^{\circ}$ parallel, is in the Southern Rocky Mountain Province. East of that line is the Great Plains Province, which is further divided into the Colorado Piedmont, north of a line paralleling, and about $25 \mathrm{miles}$ south of, the river, and the Raton section, south of that line. The Colorado Piedmont is a late, mature to old, elevated plain; the Raton section is a trenched peneplain (fig. 2).

Climate in the study area is affected greatly by differences in elevation. It has been said that "The difference in average temperature between Pikes Peak and Las Animas, 90 miles to the southeast, is about the same as that between southern Florida and Iceland" (Berry, 1959). 


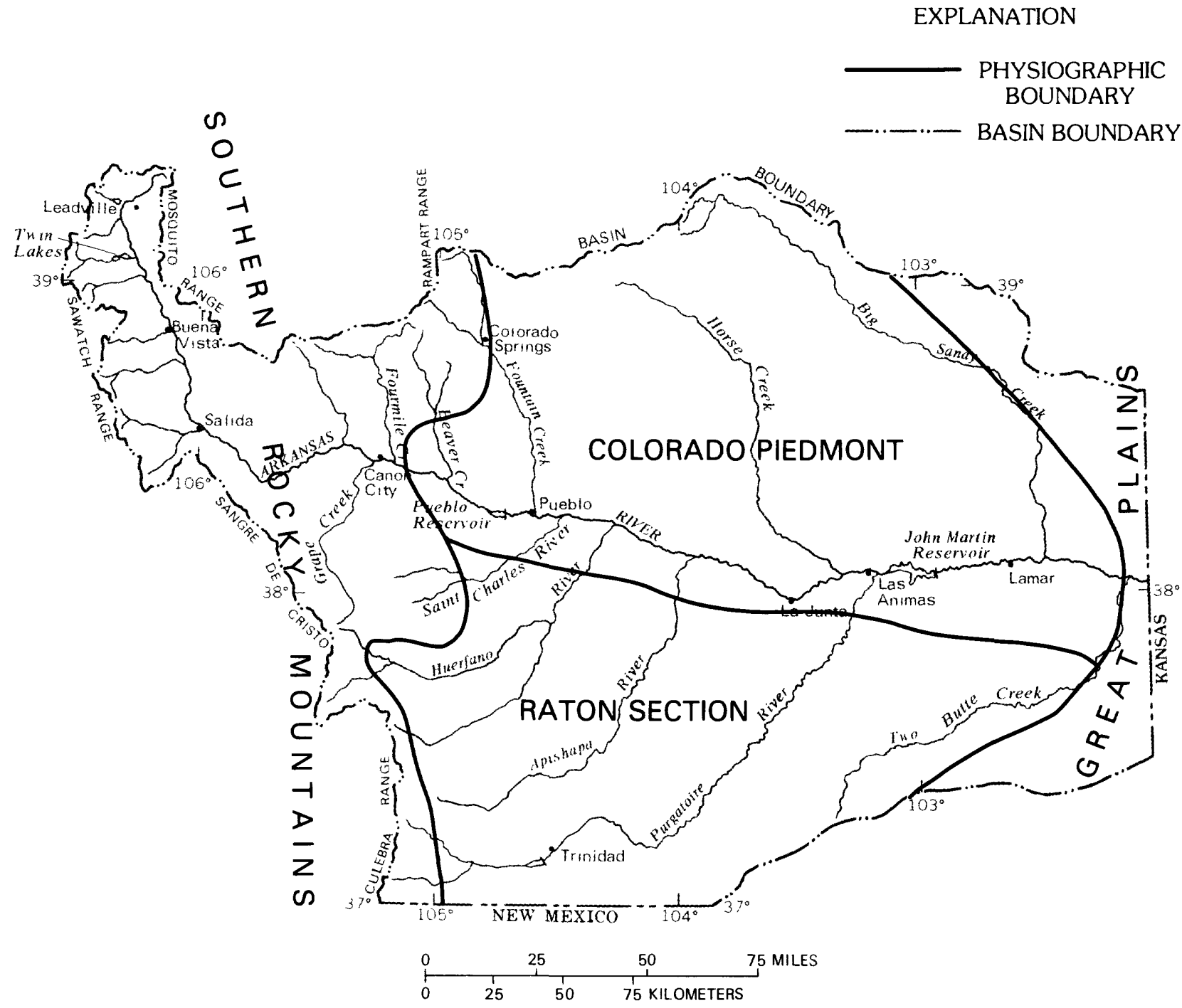

Figure 2.--Physiographic setting. (After Fenneman, 1931)

Mean annual precipitation ranges from less than 10 inches in the plains part to more than 40 inches at the crest of the highest mountains (fig. 3 ). Distribution of precipitation with time is uneven; much of the precipitation in the plains is from intense summer storms. Inclusion of these storms in the record makes the mean annual precipitation much greater than the mode of the mean daily precipitation. Precipitation in the mountains results in the formation of a deep snowpack that accumulates during winter months, and that melts and runs off in the spring and early summer. Both storm runoff and snowmelt result in a large percentage of annual streamflow occurring during a relatively short time. 


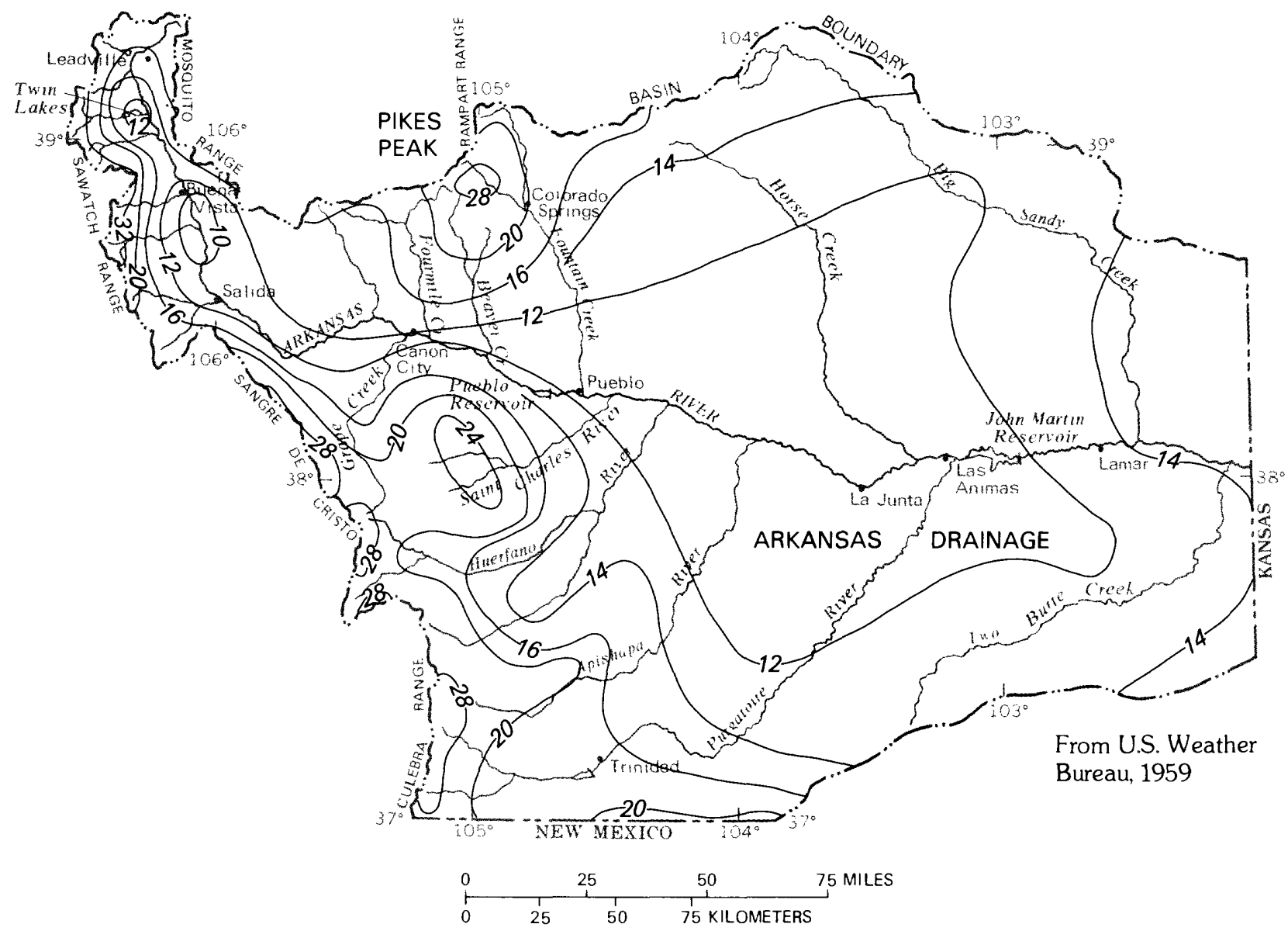

Figure 3.--Mean annual precipitation.

\section{Drainage}

The Sawatch, Culebra, and Sangre de Cristo Ranges form the western boundary of the Arkansas River basin (p1. 1). The Sawatch Range separates the northern part of the basin from the headwaters of the Gunnison River, the Roaring Fork, and the Eagle River, all in the Colorado River basin, and the Culebra and Sangre de Cristo Ranges separate the southern part of the basin from the Rio Grande headwaters. The mountains in these three ranges are among the highest in the Nation, with 23 peaks more than 14,000 feet. Streambed elevation at the point the Arkansas River flows into Kansas is 3,350 feet. 
Perennial streams in the area have their headwaters at high elevation. In the northern part of the Arkansas River upstream from Salida, most western tributaries originate in the Collegiate Peaks of the Sawatch Range. Texas and Grape Creeks flow from the crest of the Sangre de Cristo Range. Fourmile, Beaver, and Fountain Creeks originate on the slopes of Pikes Peak, another 14,000-foot mountain. Hardscrabble Creek and the St. Charles River originate in the Wet Mountains, with headwaters above 9,000 feet and 11,000 feet. The Huerfano, Apishapa, and Purgatoire Rivers have their headwaters in the Culebra Range. These streams all are sustained by mountain snowpack. Northern tributaries of the Arkansas River downstream from Pueblo, Colo., originate on the Colorado Piedmont and are ephemeral, as are smaller southern tributaries between, or tributary to, the major southern perennial tributaries. Mean annual runoff decreases from more than 30 inches from the mountain peaks to less than 0.1 inch from the Colorado Piedmont, downstream from Pueblo (fig. 4).

EXPLANATION

- $0.5-$ LINE OF EQUAL MEAN

ANNUAL RUNOFF-Interval, in inches, is variable
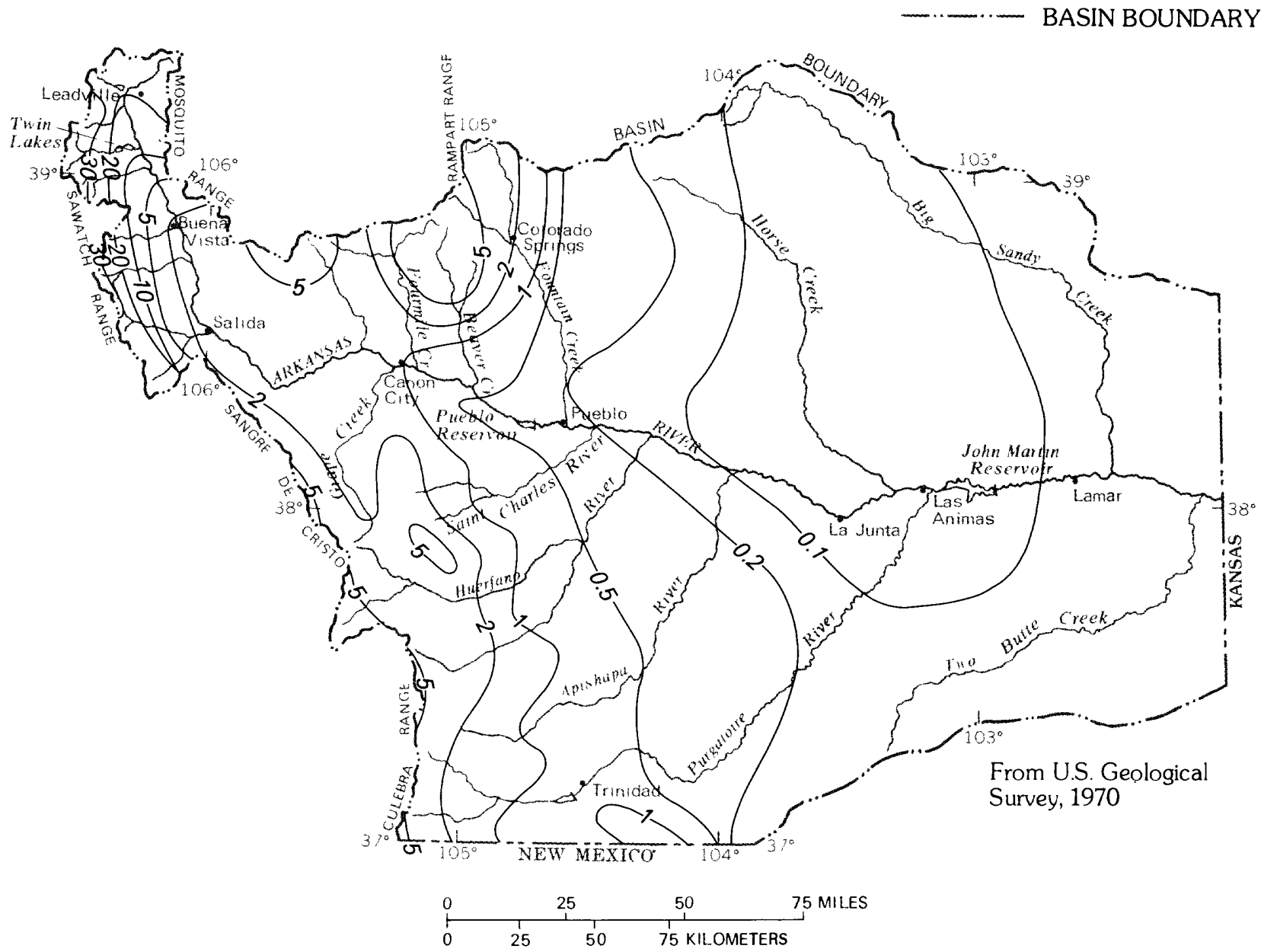

Figure 4.--Mean annual runoff. 


\section{HISTORY OF WATER DEVELOPMENT}

Water development in the Arkansas River basin of Colorado can be divided into four distinct, progressive, generally chronological phases: (1) Development of direct diversions; (2) development of water storage; (3) importation of water by transmountain diversion; and (4) development of ground water.

Earliest development was the diversion of water from a flowing stream for direct use, either to irrigate a farm plot, to wash gravel in a placer-mining operation, or to turn a mill wheel. The earliest appropriation date listed in Irrigation Division 2, March 31, 1859, is that of the Hicklin ditch on Greenhorn Creek. Evidence indicates that irrigation was being used at this location much earlier. Lieutenant E.G. Beckwith, traveling through the area with Captain John W. Gunnison's party in 1853, reported that the waters of Greenhorn Creek were diverted to water the fields of six Mexican families in the valley. And, while no mention was made of irrigation, George Frederick Ruxton, who passed through the area in 1847, found a settlement of FrenchCanadian hunters and their Indian wives farming the Greenhorn Valley (Taylor, 1963).

There is history of still earlier irrigation in the basin. In the valley of the Purgatoire River, just downstream from the present town of Trinidad, an irrigation ditch was dug by the Bents (of Bent's Fort fame) in 1847. A man named Hatcher operated the enterprise and the ditch has been called Hatcher ditch. After a short period, the ditch was abandoned. In 1864, this ditch was taken over and rehabilitated by John Lewelling. The Lewelling-McCormack Ditch is still in operation (McHendrie, 1928).

These early ditches irrigated small plots on the flood plain of the Arkansas River or its tributaries; they were operated by one or two farm units. Some ditches served the headgates of several farms, but all were located on the flood plain and required little or no engineering to get the water to the land. Many had no diversion dam, but relied on a headgate at stream level.

After all the irrigatable acres on the flood plain became occupied, irrigation began on the terraces above the river bottom. Getting water to the terraces was more difficult, requiring more engineering and more expense. To overcome these obstacles, a number of farm units would band together and form a mutual irrigation company. The area served by flood-plain and tributary ditches was of the magnitude of tens or hundreds of acres; the area served by mutual ditch companies was of the magnitude of thousands or tens of thousands of acres. To justify the expense of such an undertaking, these mutual companies commonly bought earlier water rights of the smaller ditches.

By the middle $1880^{\prime} \mathrm{s}$, the Arkansas River and its tributaries were fully appropriated for normal or average years. In most areas, water rights later than 1887 are little more than flood rights, and will not provide a dependable supply. However, water is available as high flow during snowmelt and after summer rainstorms. Also, flow occurs in the river at times other than the irrigation season. These flows have been diverted to fallow ground to recharge soil moisture and the ground-water system, and, to some extent, this practice still is followed. However, these early or late season and peak flows generally are not available to or wanted by direct-flow water rights, as these flows come at times inconvenient to farming operations, or at rates in excess of canal capabilities. 
Water-storage rights were developed to use more fully the flow not available to direct diversions. Reservoirs, both on-stream and off-stream, were constructed to store water in excess of direct-flow water rights, and streamflow outside of the irrigation season. Irrigation water is stored for later use during the growing season; municipal and industrial water is stored to meet a constant demand.

There is a legend that a placer miner established the first transmountain diversion in the Arkansas River basin; finding no water left in the stream to run his sluice box, the miner walked through a mountain saddle and found a fu11, flowing stream on the far slope. He dug a ditch through the saddle in the mountain crest to bring this water to his claim. Whatever the initial circumstances, transmountain diversions into the Arkansas River basin began around the turn of the 20 th century, and are continuing to be developed today. These diversions vary in size and complexity from open ditches through low spots in the mountain-chain crest, to vast collection systems of tunnels, conduits, and storage reservoirs, that convey the water from the western slope to a single master tunnel, thence through the Continental Divide to the eastern slope. This complex diversion is possible, because there is unappropriated water in the western part of Colorado. Colorado's western slope is not able to use all its share of water, assigned by the Upper Colorado River Compact.

Ground water has been used in the basin from the onset of settlement. The earliest settlers dug wells, and later erected windmills; stock wells long have been in use in the uplands. After all the inexpensive, gravity-flow sources of surface water had been fully used, development of large-volume wells for irrigation, municipal, and industrial uses began. Estimated pumpage of ground water in the Arkansas Valley is shown in figure 5, and indicates a drastic increase in ground-water use during the $1950^{\prime} \mathrm{s}$. Withdrawal from alluvial aquifers in the basin increased to the point where effects on the river system became a problem. In 1969 the law governing use of water in Colorado was changed, making water rights from aquifers hydraulically connected to streams work in priority with surface-water rights (Radosevich and others, 1975).

Water development was not restricted to agricultural purposes. As cities and industries in the valley expanded, water supplies necessarily increased with them. The Colorado State Constitution gives preference to domestic and municipal use over industrial and agricultural use. As agricultural land is no longer farmed, the water supply that once served that land is used for other purposes. As technologies and economies continue to change, the priorities of water use will continue to change. This change may not always be in one direction--from agricultural use toward municipal and industrial use. The recent national fuel crisis highlighted the fact that synthetic fabrics manufactured from petroleum products always might not be available readily, and the economy might have to depend on farm-grown fiber. Hydroelectric power, especially from low-head, run-of-the-river-type generators, increasingly is becoming attractive. Future economic development might change the type of water development in the Arkansas Valley. 


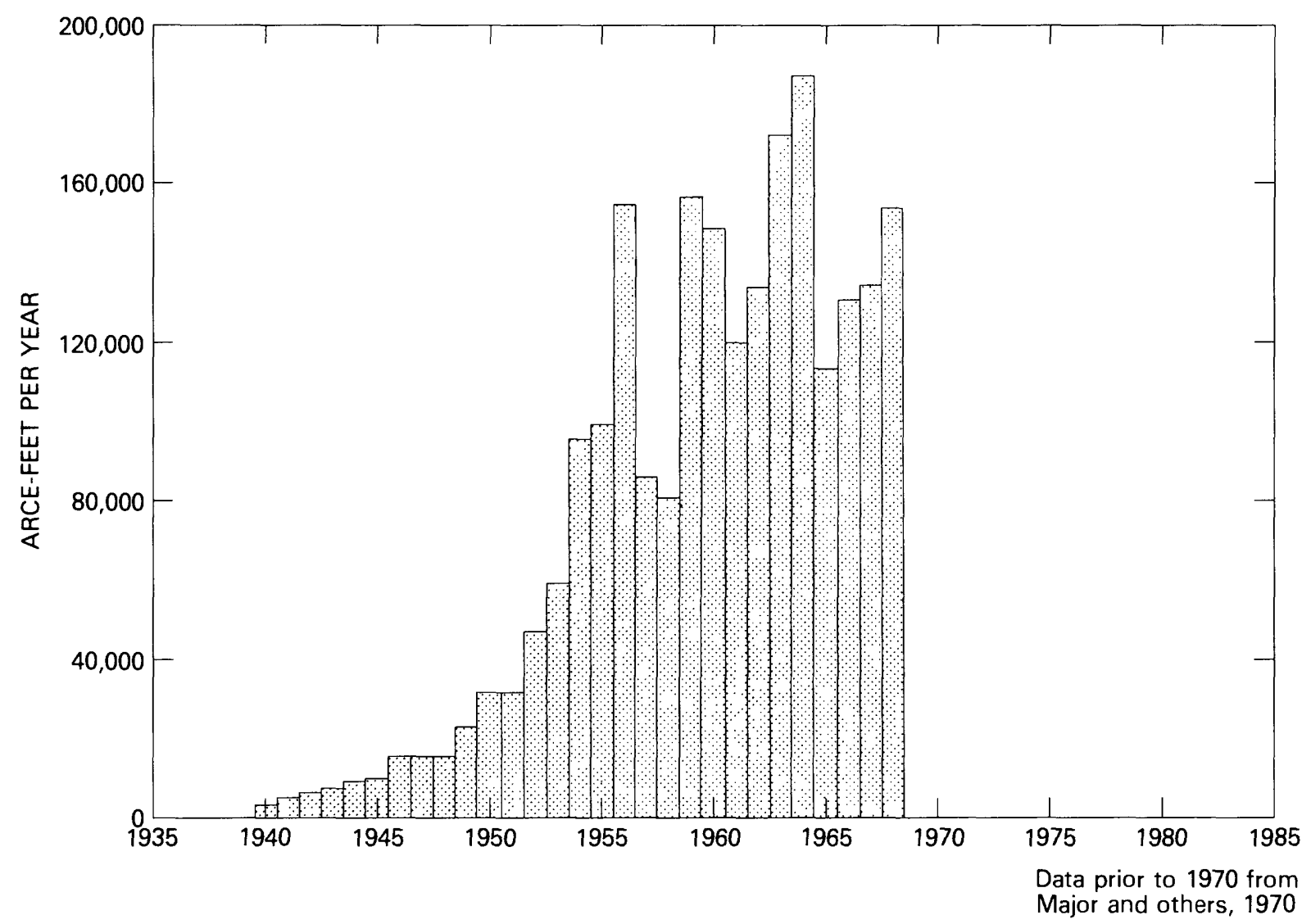

Figure 5.--Development of ground-water use.

\section{WATER-SYSTEMS OPERATIONS}

Water systems in the Arkansas River basin described here are those with complex operations, such as transmountain diversions, systems involving considerable storage, or systems requiring exchanges to operate. These systems generally can be divided into four categories: municipal systems, irrigation systems, industrial systems, and multipurpose systems. A schematic diagram accompanies each of the following system descriptions. The general location of each of these schematic diagrams is outlined on plate 1 in the pocket. Plate 1 also shows many of the drainages and land features that are referenced throughout the text. 


\section{Municipal Systems}

The complex water-collection systems of four municipalities in the area are described herein: Colorado Springs, Pueblo, Trinidad, and Walsenburg. Other major communities in the basin obtain their water directly from the river or from nearby well fields. Lamar obtains a part of its supply from a well field located in the flood plain of Clay Creek; this well field is partially recharged with water delivered through the Fort Bent Canal.

\section{City of Colorado Springs}

Unlike most cities of its size, Colorado Springs is not located on a major stream that can be used for a direct source of water supply; therefore, the city must rely on a complex system of sources for its water. Despite its location, the city has developed resources capable of producing an average annual water supply of 123,200 acre-feet, of which 52,400 acre-feet are considered potable. In addition, future planned development will produce an additional 56,200 acre-feet per year, resulting in an annual water supply of 179,400 acre-feet. ${ }^{1}$

The raw water supply developed for the city is from a combination of sources that is outlined in table 1 and shown in figure 6 . Volumes and percentages for 1982 from each source also are listed in table 1 . The 1982 figures do not include reuse and are not necessarily typical of future use. Plans for future development include an expansion of the Homestake collection system (Homestake Project, Phase II) and the Eagle-Arkansas Project, which are both transmountain diversions from the Colorado River basin into the Arkansas River basin.

The mountain collection system (fig. 7) consists of the Pikes Peak watershed, the Northfield watershed, and the Penrose-Rosemont watershed. The Pikes Peak watershed is further divided into the South Slope watershed and the North Slope watershed. An average annual water supply of about 16,400 acre-feet is produced from the mountain collection system and 3,200 acre-feet from local streamflow. The South Slope watershed (fig. 8) is located on the south side of Pikes Peak, southwest of the city. It consists of 7 reservoirs with a combined capacity of 6,862 acre-feet that intercept flow from the drainage basins of 11 streams. Water is transported through a series of channels, tunnels, and aqueducts to city water-treatment plants. Enroute, the water generates electrical power at two sites.

The outermost area of the South Slope watershed is the East Fork West Beaver Creek, including Bighorn and Wilson Reservoirs. Water is diverted from the East Fork West Beaver Creek through the Strickler Tunnel to Boehmer Creek in the Middle Beaver Creek basin. The water from this basin is regulated by Boehmer, Mason, and McReynolds Reservoirs. Mason and McReynolds Reservoirs are connected by a 20-inch pipeline.

${ }_{1}$ McCullough and Miskel, 1974, and Edward Martinez, Colorado Springs Department of Utilities, oral and written communs., 1983. 
Water is diverted from the Beaver Creek drainage into Ruxton Creek drainage via the St. Johns Tunnel. This tunnel diverts directly from Mason or McReynolds Reservoirs. Diversions through St. Johns Tunnel are limited to 18.9 cubic feet per second.

Table 1.--Developed sources of raw-water supply for the city of Colorado Springs, 1982

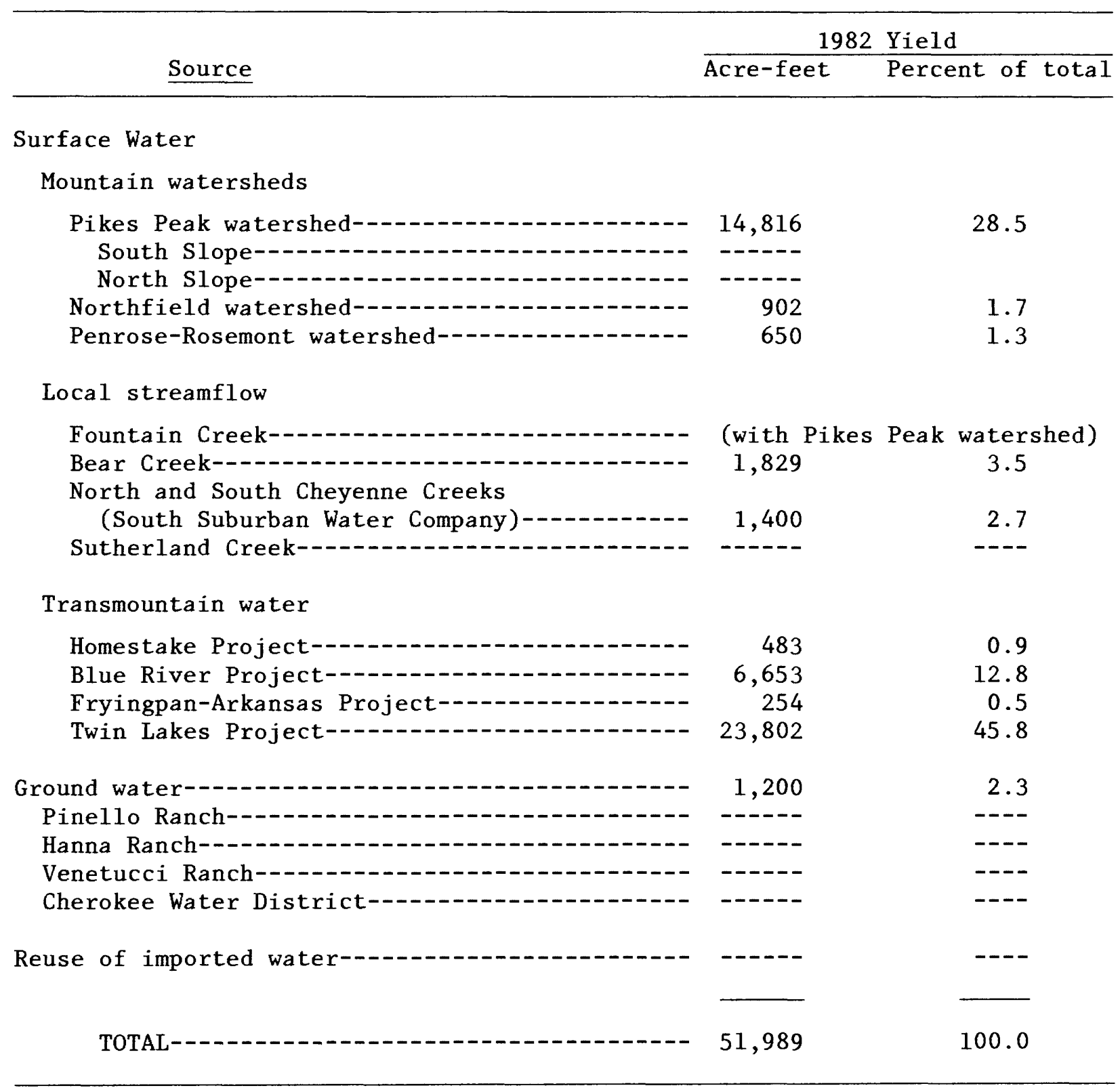


뗭 뿡
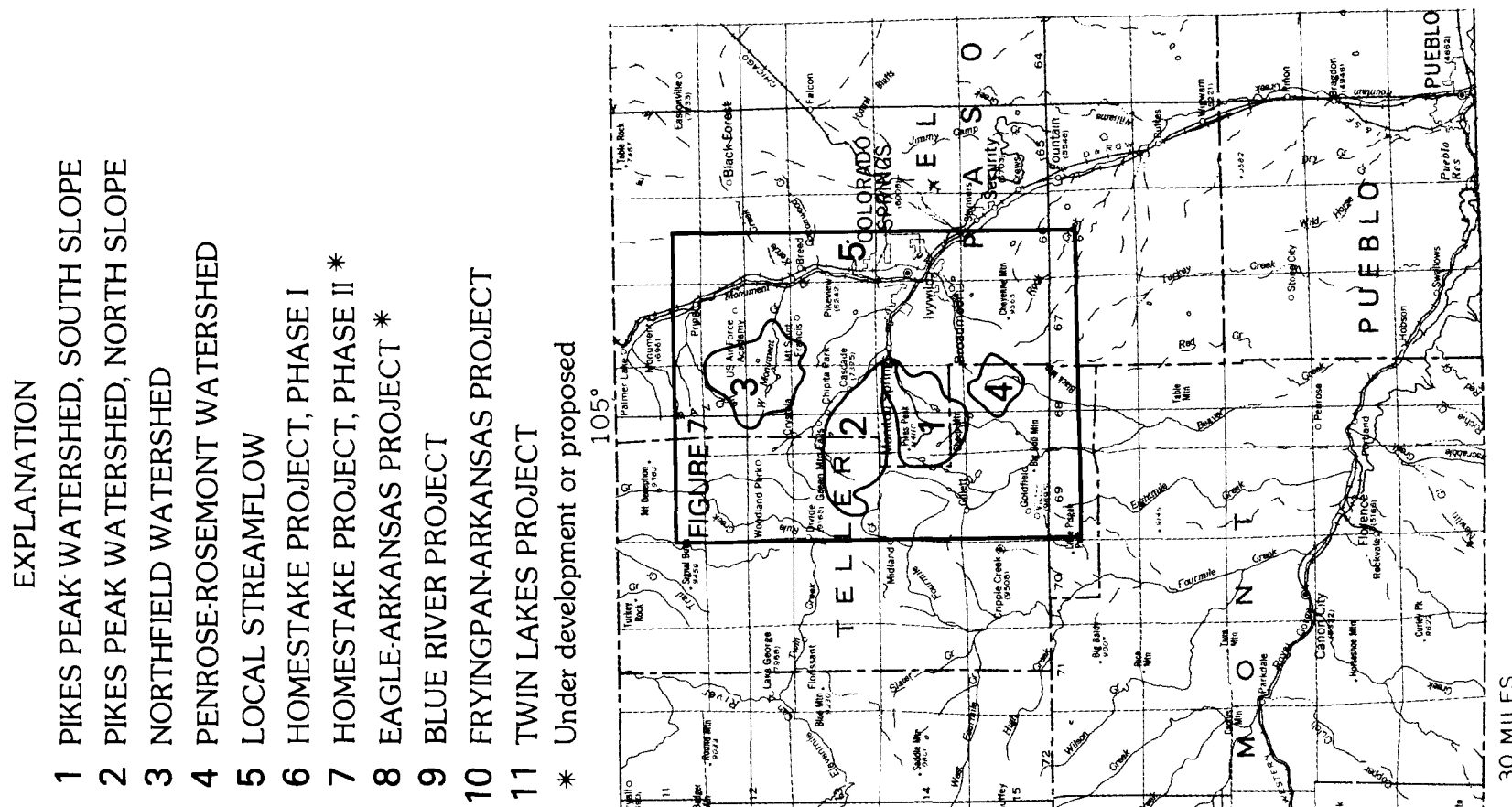

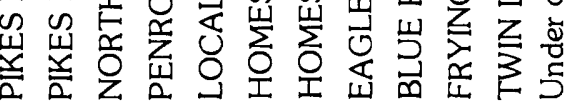

- -

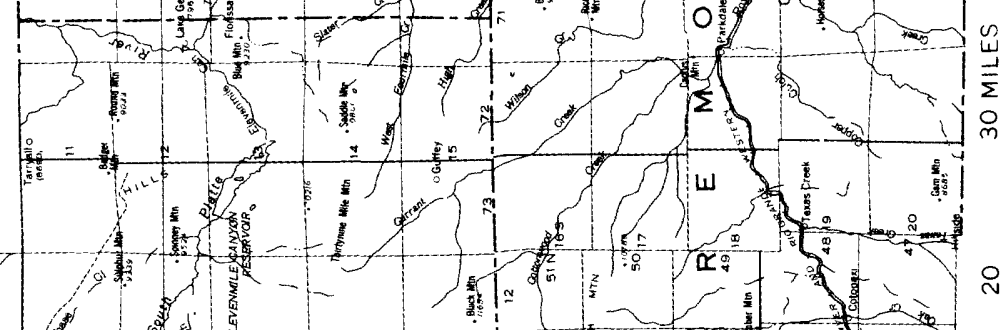

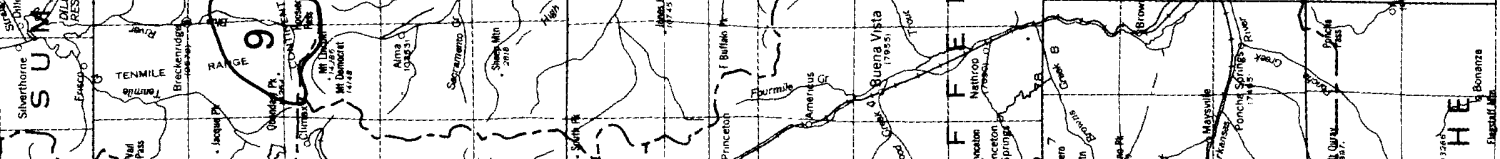
(2) 


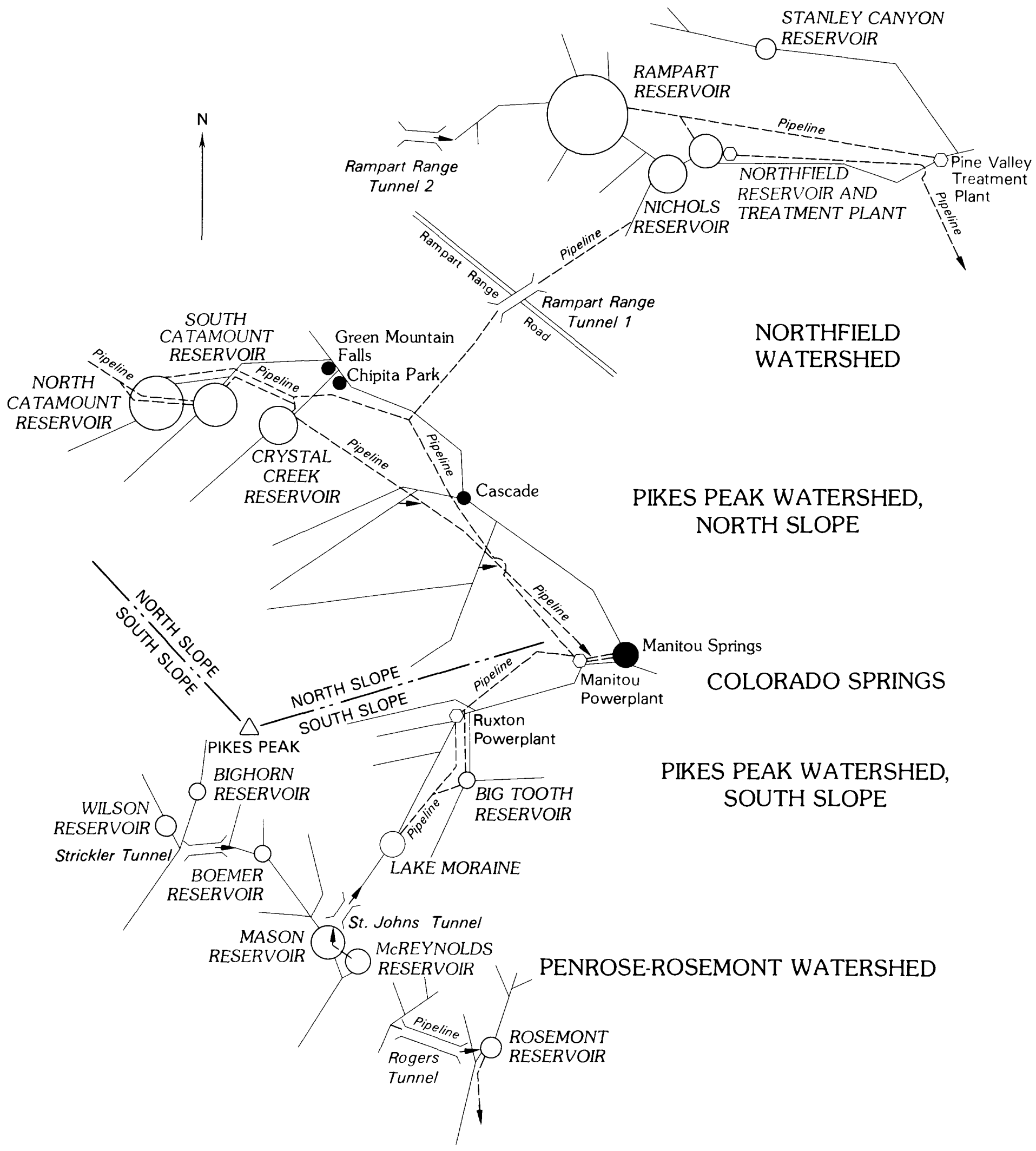

Figure 7.--Mountain collection system for the City of Colorado Springs showing relationship of watershed schematics, figures 8 through 11 . (Modified from map by City of Colorado Springs Public Utilities Department.) 


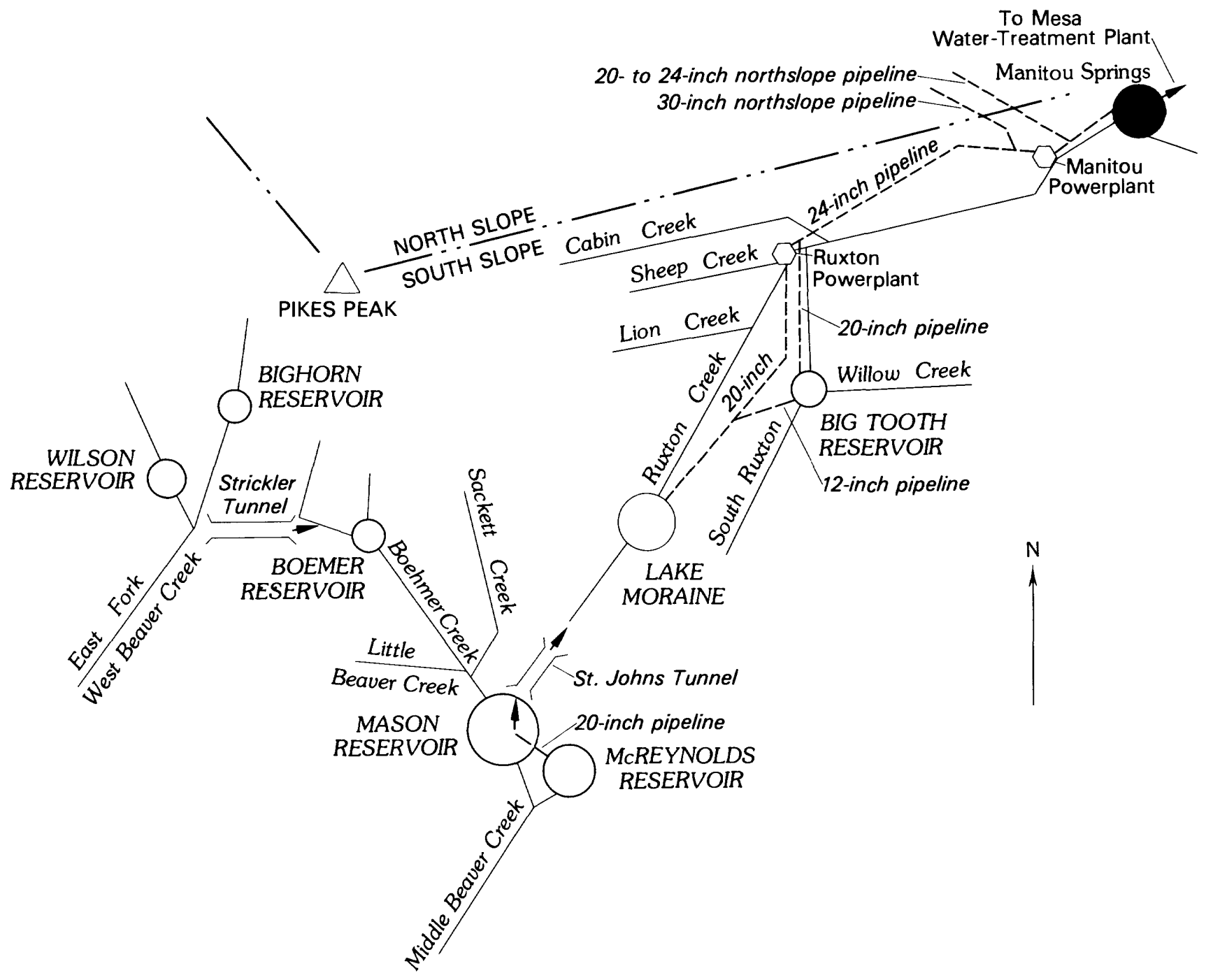

Figure 8.--South-slope Pikes Peak watershed, Colorado Springs mountain collection system.

A short distance down the channel of Ruxton Creek the water enters Lake Moraine. A 20-inch pipe from Lake Moraine serves as a penstock for the Ruxton powerplant. Some of the flow can be diverted into Big Tooth Reservoir at the confluence of South Ruxton and Willow Creeks. Big Tooth Reservoir is connected with the afterbay of Ruxton powerplant by a 20-inch pipeline. From the Ruxton powerplant afterbay, water diverted from Lake Moraine and Big Tooth Reservoirs, together with waters of Lion Creek, Ruxton Creek, and Sheep Creek, are conveyed in a 24-inch pipeline to the penstock of the Manitou Springs powerplant. Enroute, the 24-inch pipeline intercepts flow from Cabin Creek and the 30-inch new North Slope pipeline. After generating power in the Manitou powerplant, the inflow water from Ruxton Creek intake (and settler), and from the 20- to 24-inch old North Slope pipeline, is mixed in the afterbay of that powerplant. From there, the water flows to the Mesa water-treatment plant. 
The North Slope watershed is located on the north slope of Pikes Peak, west of Colorado Springs (fig. 9). Native water originating in the watershed is collected in Crystal, South Catamount, or North Catamount Reservoirs, which have a combined capacity of 18,120 acre-feet. Flow from the 30-inch Montgomery pipeline can be added to the storage in North Catamount and South Catamount Reservoirs. The flow in Montgomery pipeline usually originates in the Blue River system (Colorado River basin); however, the capability exists, at the divide pumping station, to obtain water from the Fryingpan-Arkansas, Twin Lakes, or Homestake Projects. Storage of imported water usually is limited to North Catamount and Crystal Reservoirs. Runoff from South Catamount Creek usually is sufficient to maintain South Catamount Reservoir.

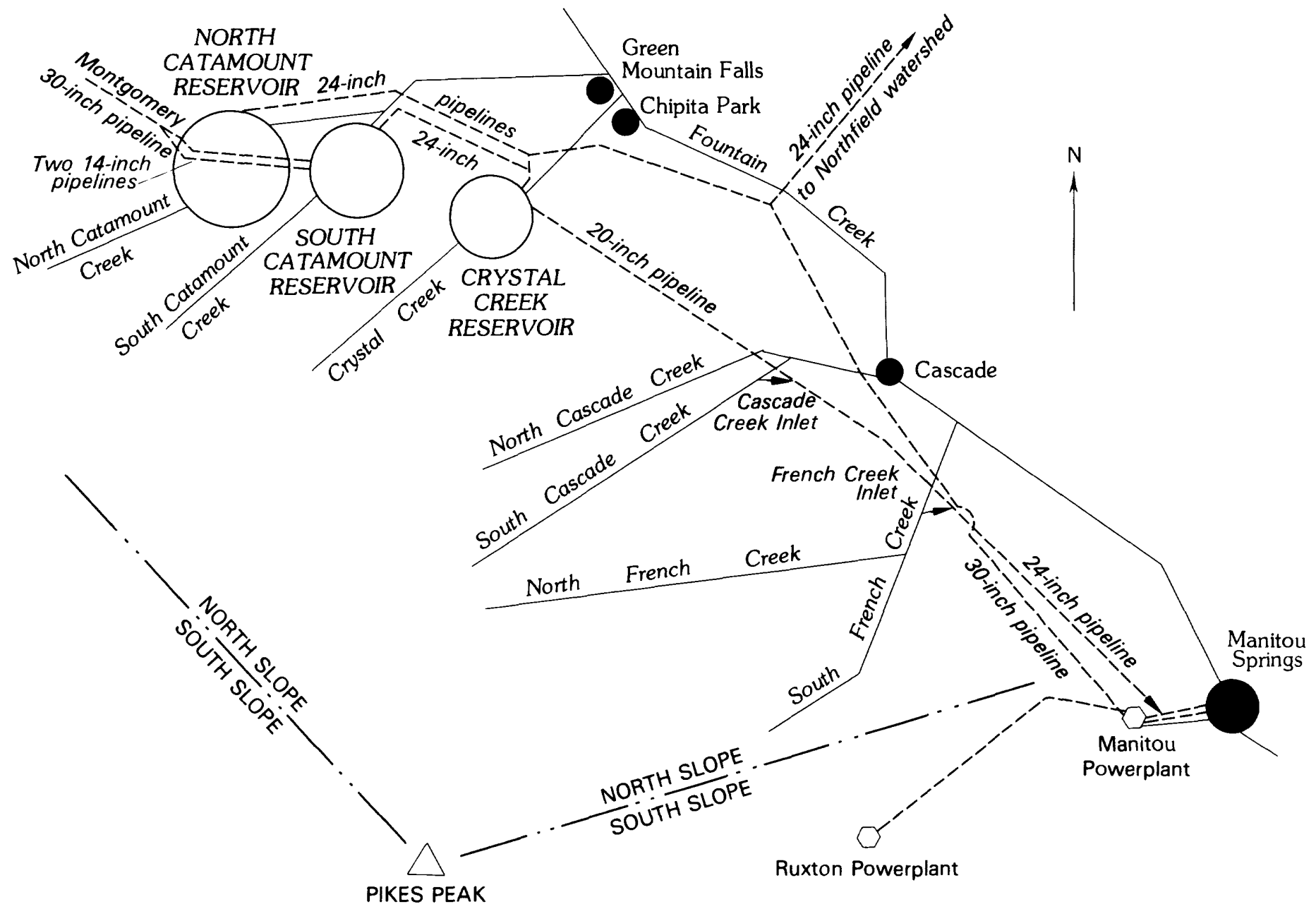

Figure 9.--North-slope Pikes Peak watershed, Colorado Springs mountain collection system. 
Water can be released from any of the three reservoirs into a 24-inch pipeline to the Northfield storage system on West Monument Creek. From turnouts on this (24-inch) pipeline, water can be diverted to the towns of Green Mountain Falls and Chipita Park, or through a 30-inch pipeline to the penstock of the Manitou powerplant.

A second 20- to 24-inch pipeline conveys water from the three North Slope reservoirs to the afterbay of the Manitou powerplant. This line also intercepts the flow of North and South Cascade Creeks and French Creek. Turnouts from this pipeline can direct water to the towns of Cascade and Manitou Springs .

The Northfield watershed (fig. 10) is located on the Rampart Range northwest of Colorado Springs. The Northfield watershed produces only a minor proportion of Colorado Springs water supply locally, but the reservoirs are important for regulating water from other sources. The three Northfield reservoirs--Rampart, Nichols, and Northfield--have a combined capacity of 41,748 acre-feet, 40,886 acre-feet of which is in Rampart Reservoir. Water from the 48-inch Homestake pipeline enters the Northfield watershed through Rampart Range tunnel 2, which discharges into Rainbow Gulch. Water conveyed by the Homestake pipeline usually is water from the upper Arkansas basin via Trout Creek which is Homestake, Fryingpan-Arkansas, or Twin Lakes Project water; but the capability exists to divert Blue River water into Rampart Reservoir at the divide pumping station. North Slope water enters the Northfield system through a 24-inch pipeline in Rampart Range tunnel 1 and flows into Nichols Reservoir.

Water from Rampart Reservoir flows through a 42-, 36-, and 30-inch pipeline to the Pine Valley water-treatment plant. Water from this line can be diverted to the Northfield Reservoir. Water also can be released from Rampart Reservoir downstream to Nichols Reservoir. Water from Nichols Reservoir is discharged to Northfield Reservoir by channel flow. Northfield Reservoir supplies the Northfield water-treatment plant. (Stanley Canyon Reservoir, Reservoir No. 2, is no longer a part of the Colorado Springs system; it has been leased to the U.S. Air Force Academy.)

The Penrose-Rosemont watershed (fig. 11) is located southwest of Colorado Springs on Gold Camp Road. Rosemont Reservoir, with a capacity of 2,538 acre-feet, is located on East Beaver Creek. Water also is diverted from Gould Creek to a 20-inch pipeline inside Rogers Tunnel. From Rosemont Reservoir, water is transported through a 10-inch pipeline to Fisher Canyon and Penrose Reservoirs, or to the Broadmoor water-treatment plant.

About 5 percent of the water consumed annually by Colorado Springs comes from local streams, including Fountain Creek, Bear Creek, North and South Cheyenne Creeks, and Sutherland Creek (fig. 12). Water is pumped from Fountain Creek at the 33rd Street pumping station. Four pumps in this station boost the water through a 20-inch pipeline to the Mesa water-treatment plant, about $1 \frac{1}{2}$ miles to the northeast. Water from Sutherland Creek no longer is diverted directly from that creek but now is diverted from Fountain Creek at the 33rd Street pumping station. 


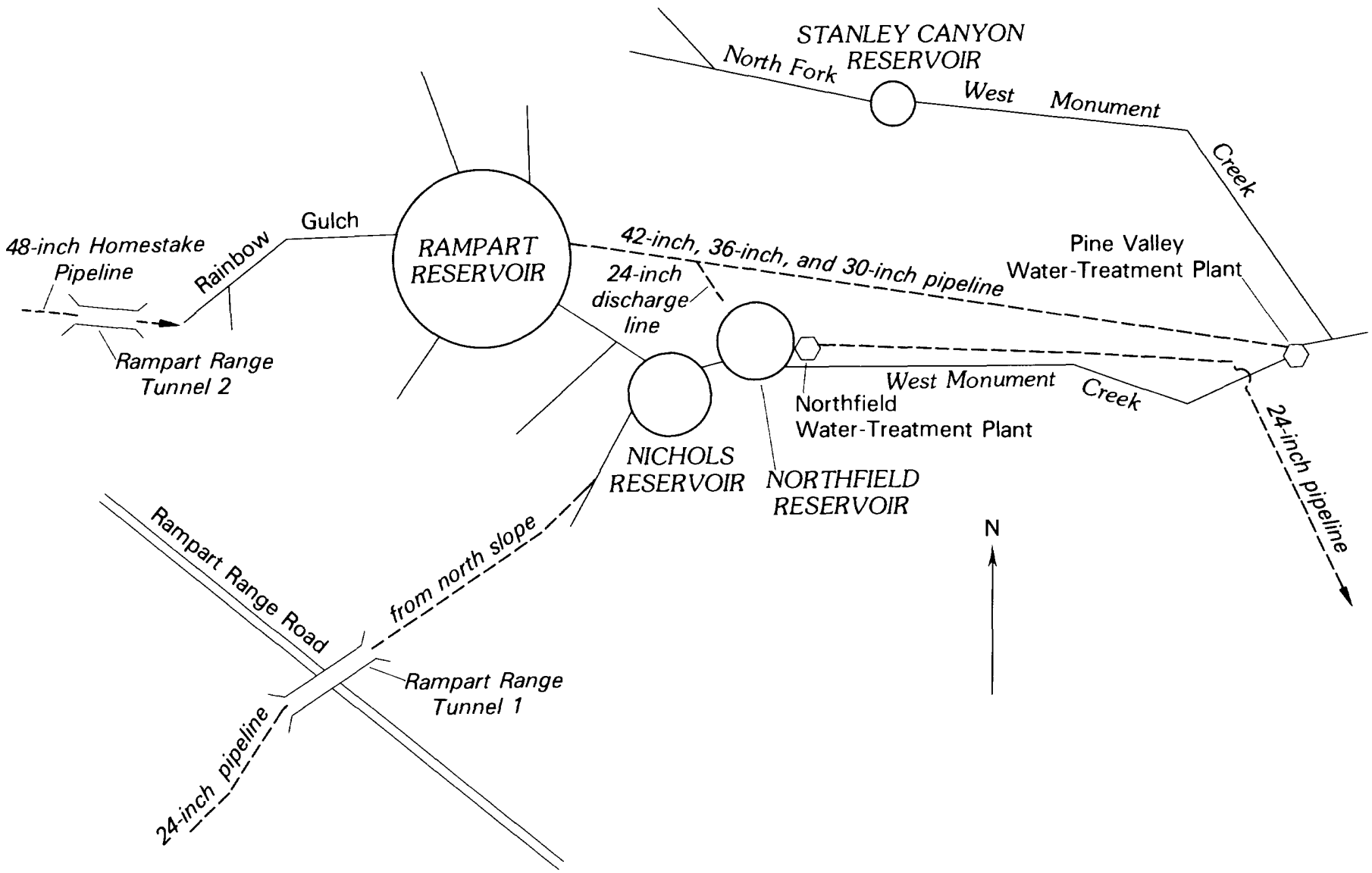

Figure 10.--Northfield watershed, Colorado Springs mountain collection system.

Bear Creek water is diverted from the stream at a point in southwest Colorado Springs. This water is treated in a settler and chlorination structure, and delivered into the distribution system in a 12-inch pipeline.

The South Suburban system diverts from North and South Cheyenne Creeks and regulates the untreated water in South Suburban and Gold Camp Reservoirs. Water from North Cheyenne Creek is diverted directly to the reservoirs and water from South Cheyenne Creek is diverted to the South Suburban pumping station and lifted into either one of the two reservoirs. During periods of excess turbidity at any of the local streamflow-diversion sites, water is not diverted and is permitted to flow downstream.

Colorado Springs imports water from the Colorado River Basin through four different systems or projects: (1) Homestake Project; (2) Blue River Project; (3) Fryingpan-Arkansas Project; and (4) Twin Lakes Project. 


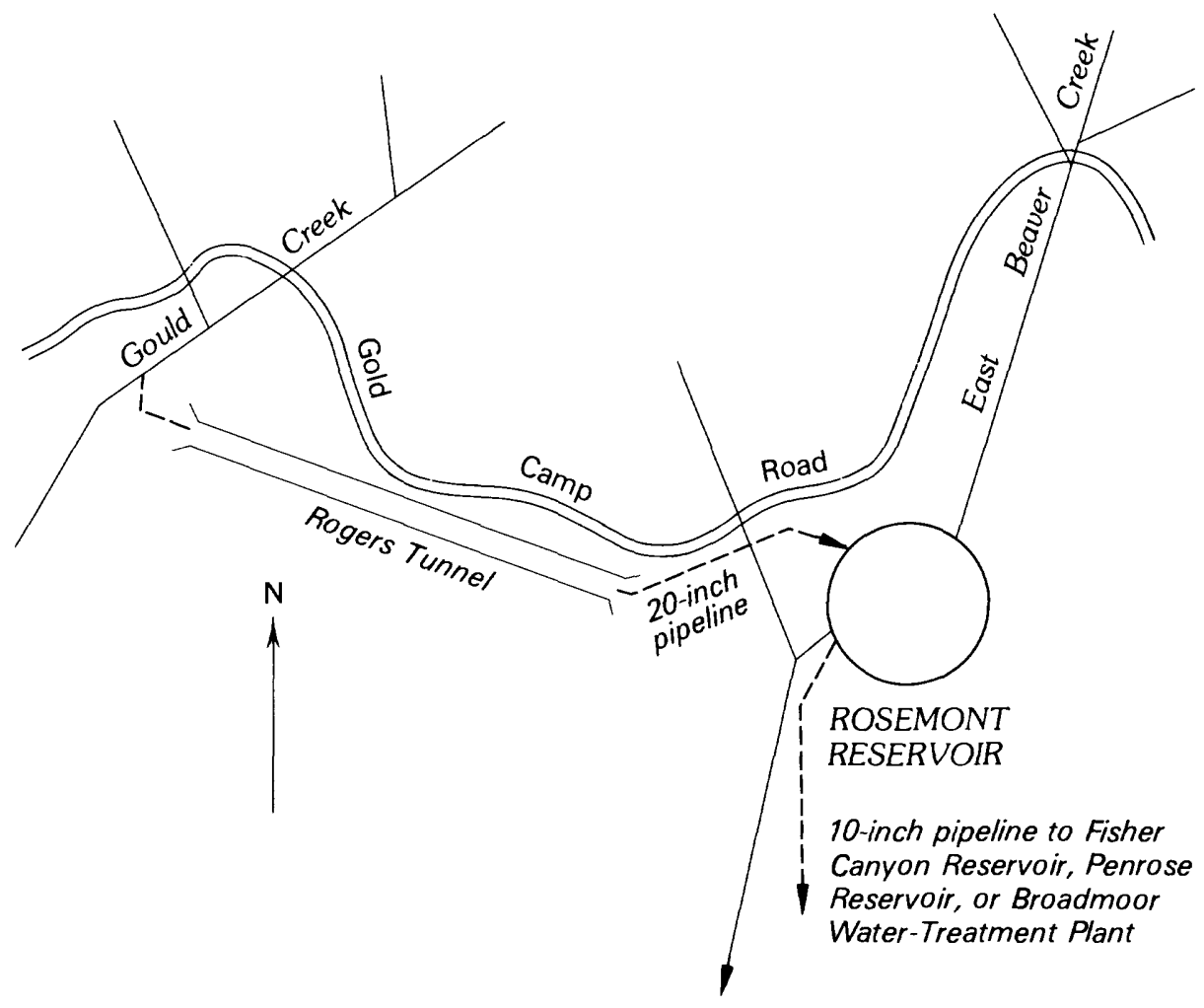

Figure 11.--Penrose-Rosemont watershed, Colorado Springs mountain collection system.

The Homestake and Blue River Projects are significant only to the Colorado Springs system in the Arkansas River basin, but the Fryingpan-Arkansas Project and the Twin Lakes Project are significant in other parts of the Arkansas River basin. For this reason, the latter two projects are discussed separately elsewhere in this report.

The collection system of the Homestake Project intercepts the headwaters of the Eagle River about 160 miles west of Colorado Springs (fig. 13). The project is a joint venture of the cities of Colorado Springs and Aurora. Colorado Springs average share of the yearly diversion is 12,900 acre-feet. Water is diverted from Fancy Creek, French Creek, Sopris Creek, Missouri Creek, Homestake Creek, and East Fork Homestake Creek. Phase II of this project would extend the collection system to intercept Whitney Creek, Fall Creek, Cross Creek, and East and West Forks Cross Creek. The water is collected in Homestake Reservoir (capacity 43,300 acre-feet), and then moved through the Continental Divide in the Homestake Tunnel. Homestake Tunnel discharges into Lake Fork Arkansas River, which in turn flows into Turquoise Lake (Sugarloaf Reservoir). 


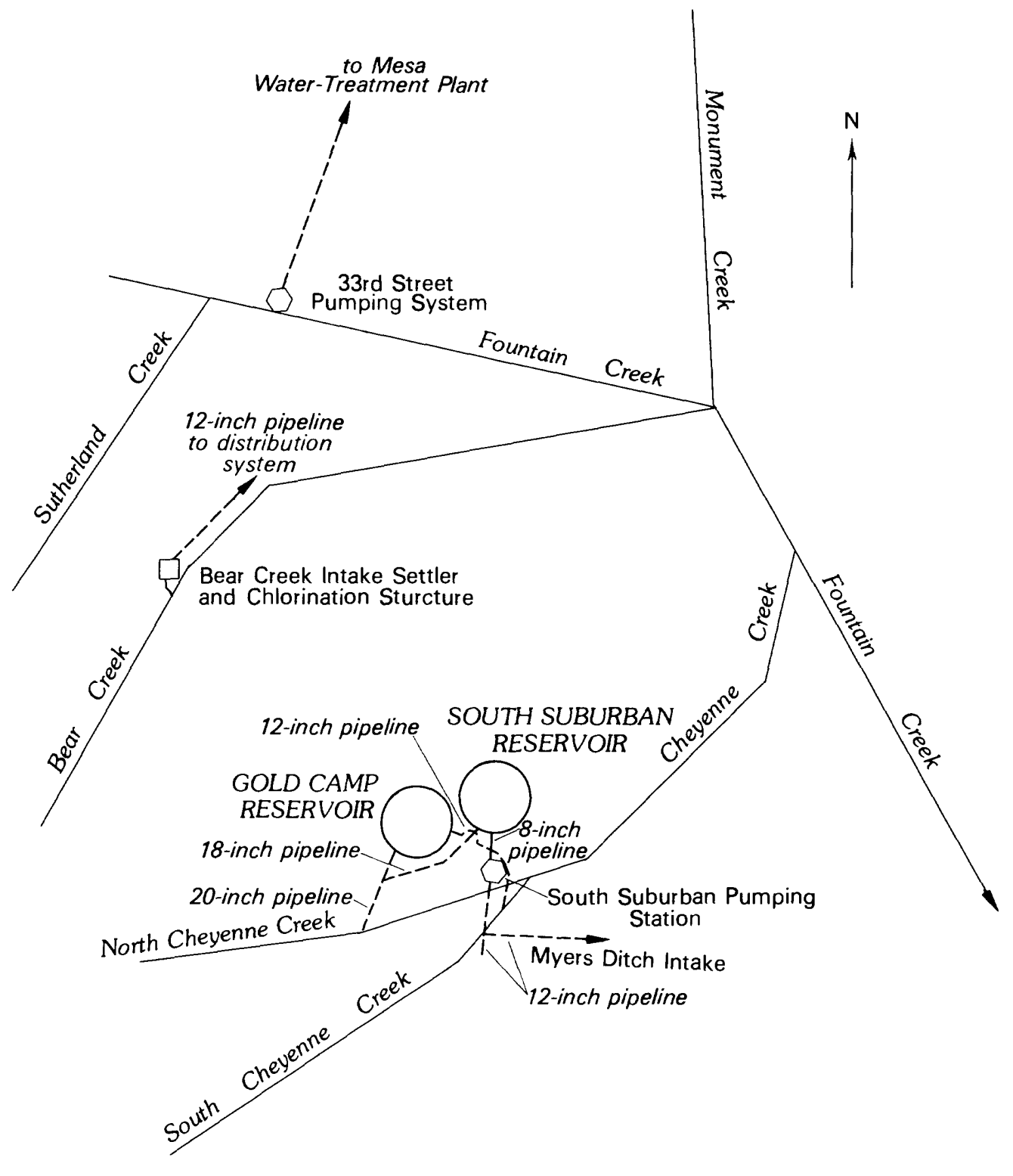

Figure 12.--Local streamflow diversions, Colorado Springs system. 


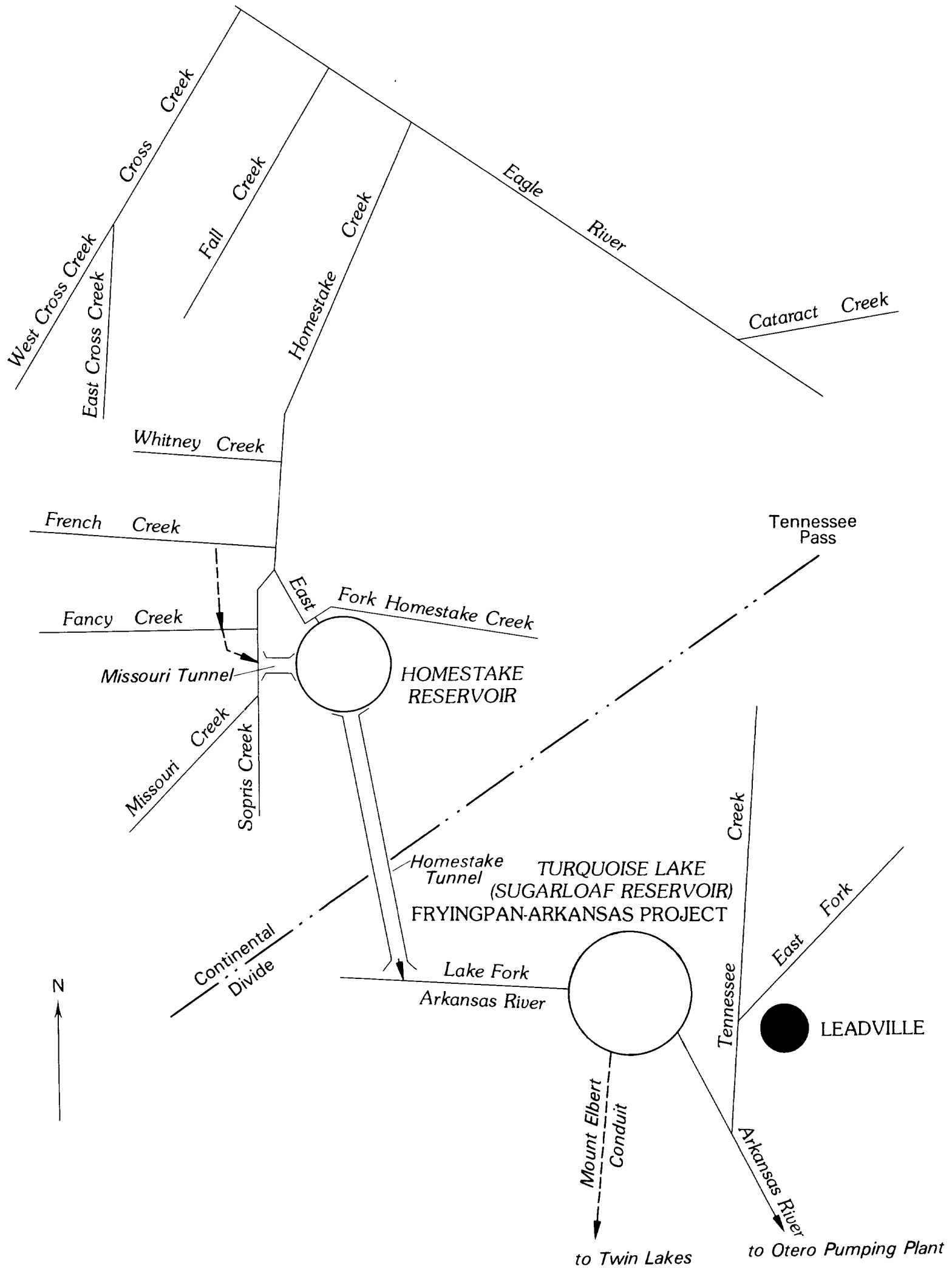

Figure 13.--Homestake Project collection system. 
Homestake Project water can be stored in Turquoise Lake, routed via the Mount Elbert conduit to Twin Lakes, or released down the Arkansas River to the Otero pumping-plant intake. The city presently (1983) has a contract with the Fryingpan-Arkansas Project (fig. 6) for 15,000 acre-feet of storage space, and with CF\&I Steel Corporation for an additional 4,000 acre-feet of storage space in Turquoise Lake.

Homestake Project water, either from Turquoise Lake or Twin Lakes, is released into the Arkansas River, then to the Otero pumping-plant intake. An outlet structure is built into the new Twin Lakes Dam that eventually will convey Homestake Project and Twin Lakes Project water to the Otero pumping plant in a pressurized conduit, which will save about 350 feet of hydraulic head or required lift for the Otero pumping station. Routing Homestake Project water in this manner also makes it available to generate power in the Fryingpan-Arkansas Project's Mount Elbert powerplant.

The Otero pumping plant supplies water to the 66-inch Homestake pipeline, which conveys it over Trout Creek Pass and across the lower end of South Park (fig. 6). The 66-inch pipeline has a bifurcation at a point south of Spinney Mountain Reservoir. Here, Aurora's water is delivered to Spinney Mountain Reservoir and flows through that reservoir into the South Platte and on to Aurora. Colorado Springs' share of the water flows in a 26-mile 1ong, 48-inch diameter pipeline to the Divide pumping plant. From there it can be diverted to either Rampart Reservoir at Northfield (fig. 10), or through the Montgomery pipeline to the North Slope reservoirs (fig. 9).

The town of Woodland Park receives an average of 225 acre-feet per year from the Homestake pipeline. In exchange for this water, the Cherokee Water District delivers a like quantity to the east side of Colorado Springs.

The planned Eagle-Arkansas Project would intercept the waters of Cataract Creek and other headwater tributaries of the Eagle River and convey them, via Tennessee Pass, to Tennessee Creek in the Arkansas River basin. Colorado Springs expects to realize an annual supply of 2,700 acre-feet of water from this source.

The collection system of the Blue River Project is in the headwaters of the Blue River near Hoosier Pass, northwest of Fairplay, Colorado (fig. 14). This system consists of a series of diversion dams, conduits, reservoirs, and tunnels that intercept the headwaters of the Blue River and six tributaries. The diverted streams are the Blue River, Crystal Creek, Spruce Creek, McCullough Creek, West Hoosier Creek, and East Hoosier Creek. Storage in upper Blue Lake is 2,120 acre-feet. Blue River Project water crosses the Continental Divide via the Hoosier Tunnel and is stored in the 5,100-acre-foot Montgomery Reservoir. From Montgomery Reservoir, the water is conveyed about 70 miles across South Park in the 30-inch Montgomery pipeline. At the Divide pumping station, it is possible to divert Blue River water through the Homestake pipeline into Rampart Reservoir (fig. 10). Usually, however, the water is conveyed by the Montgomery pipeline to reservoirs on the North Slope of Pikes Peak. The average annual yield of the Blue River Project is 12,100 acre-feet. 


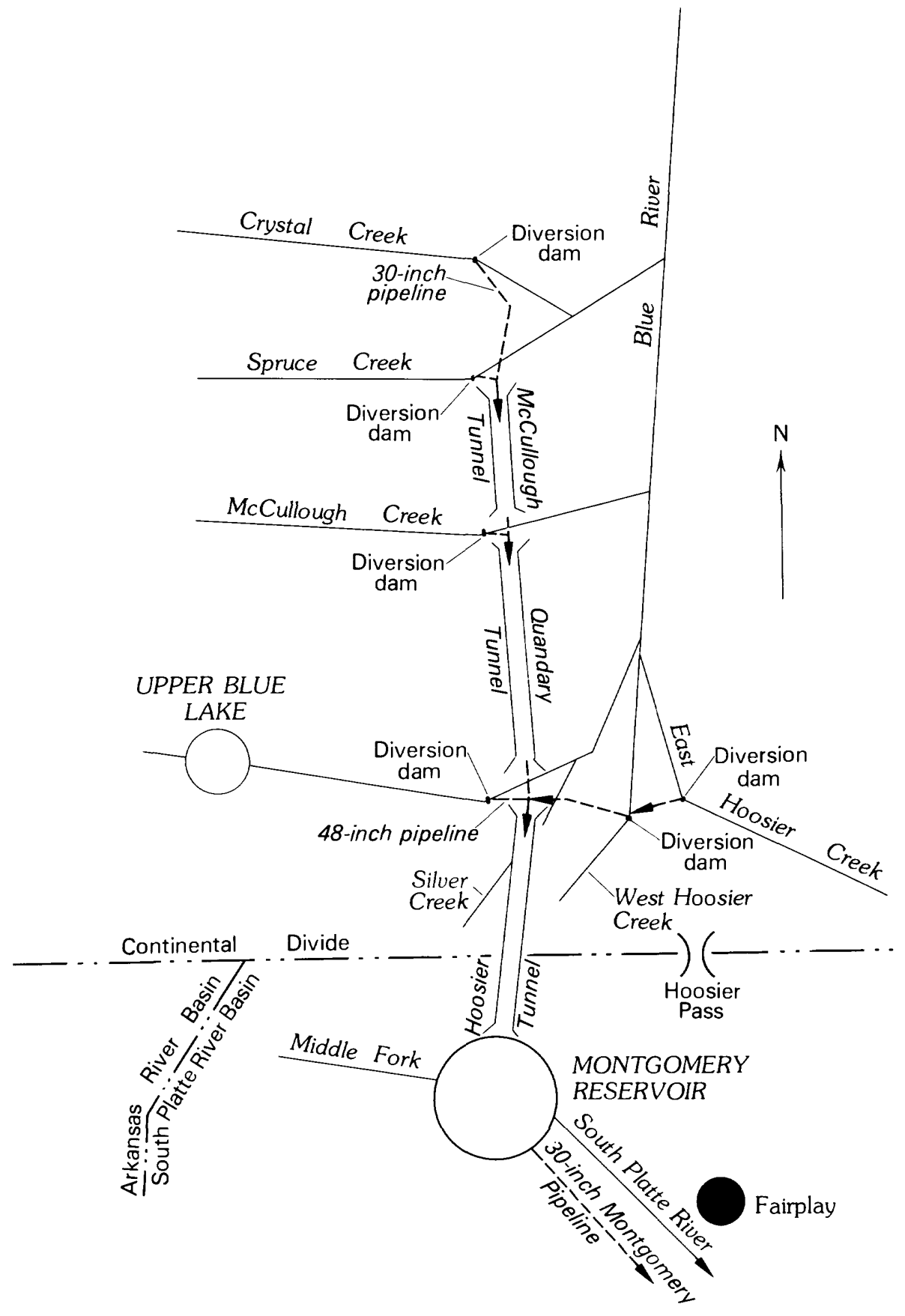

Figure 14.--Blue River Project collection system. 
The Fryingpan-Arkansas Project is a multipurpose U.S. Bureau of Reclamation Project described in detail later in this report. Colorado Springs, with the nearby communities of Fountain, Security, Widefield, and Stratmoor Hills, are participants in the project and will receive water from that source. Colorado Springs eventually expects to receive 14,400 acre-feet of water from the project. Delivery will be through the Fountain Valley pipeline, now (1983) under construction, from Pueblo Reservoir to the south side of Colorado Springs. Until construction of the Fountain Valley pipeline is complete, deliveries of Fryingpan-Arkansas Project water are being made through the Otero pumping station and Homestake pipeline.

In recent years, Colorado Springs has participated in the winterwater-storage program, an outgrowth of the Fryingpan-Arkansas Project operations. In 1981, 1982, and 1983, participation has been by storage in Twin Lakes Reservoir, with simultaneous release of return flow from imported water down Fountain Creek. When the winter-water-storage program is in operation, Colorado Springs stores in its reservoir inflow in addition to that allowed by priority.

The Twin Lakes Project also is described later in this report. Colorado Springs owns 49.845 percent of outstanding shares of Twin Lakes Project water; future total supply from the source is expected to be 27,000 acre-feet annually. In addition to water yielded by the project, the city also has the right to use storage in Twin Lakes Reservoir. Twin Lakes Reservoir is on Lake Creek, which has its confluence with the Arkansas River about 5 miles upstream from the intake to the Otero pumping station. Twin Lake Project water is brought into the Colorado Springs system through the Homestake pipeline.

Ground water provides a small (generally about 3 percent) but important segment of Colorado Springs water supply. Ground-water sources are the Pine11o Ranch, the Hanna Ranch, and the wells of the Cherokee Water District. The city's contract with the Venetucci Ranch (which is located just west of Security) expired.

The Cherokee Water District supplies about 225 acre-feet of water annually from their well field in the Black Squirrel Creek basin east of the city. This water is purchased from the Cherokee Water District by Woodland Park, and exchanged for a like quantity of water, delivered via the Homestake pipeline.

The Pinello Ranch is located on the flood plain of Fountain Creek immediately west of the town of Security. Fourteen wells produce from the Widefield aquifer. Water from these wells is routed through a pumping, chlorination, and metering station by a 16-inch pipeline, into the distribution system serving Security and Colorado Springs; the wells also are used for domestic purposes and irrigation on the ranch. Ground-water recharge from six ponds on the Pinello Ranch is supplied by the Stubbs and Miller Ditch; wells are an alternate point of diversion for that ditch. A discharge of 2.45 cubic feet per second is allowed annually from the wells; total yield to the system from the Pinello Ranch wells is 1,400 acre-feet per year. 
The Hanna Ranch was purchased when the city acquired the Pinello Ranch, on January 1, 1973. Located about 4 miles south of Fountain, the Hanna Ranch is the site of the new R.D. Nixon powerplant. Water rights for the Owen and Hall ditch acquired with the ranch are used, in part, in a plan of augmentation for 14 wells on the ranch. Water from the wells supply the town of Fountain, and Unit 1 of the R.D. Nixon powerplant. An average of 4,700 acrefeet per year is supplied to the powerplant from this source.

The Supreme Court of Colorado determined that Colorado water law allows municipalities "...to reuse, make successive uses, and after use to have the right of deposition of imported water..." (Radosevich and others, 1975). In recent years, Colorado Springs used an average of 6,200 acre-feet of imported return flow. Reuse of imported water is for nonpotable purposes, such as irrigation of golf courses, parks, parkways, for cleaning streets, and it may be used for cooling water to powerplants. Transmountain-return flow also is used to offset ground-water depletions at the Pinello and Hanna Ranches, to offset storage and excess diversions from the Pikes Peak watershed, South Suburban storage, and Fort Carson water reuse. For this purpose, a strict accounting of transmountain-return flow and reuse is made by Colorado Springs to the Water Commissioner (Irrigation Division No. 2, Water District 10).

\section{City of Pueblo}

The city of Pueblo obtains its water through the Pueblo Board of Water Works; a public, revenue-supported water utility. The city's raw-water supply is from three sources: (1) Direct-flow rights; (2) storage rights; and (3) transmountain diversions. The existing treatment plant is designed to process from 53 million gallons per day ( 82.0 cubic feet per second) to a maximum of 80 million gallons per day ( 123.8 cubic feet per second). At Pueblo's present size, direct flow rights satisfy municipal demand most of the year. Critical periods occur early in the spring, before snowmelt runoff begins, and in the fall, when the river is low. During these times, streamflow is supplemented with reservoir water.

The Pueblo Board of Water Works operates Clear Creek Reservoir on Clear Creek in Chaffee County (fig. 15). The storage rights for Clear Creek Reservoir include 11,439 acre-feet from the waters of Clear Creek; the reservoir also stores the Board's transmountain diversions by exchange.

Transmountain diversions, which are storable in the Arkansas River basin, are from the Ewing Ditch, the Warren E. Wurtz Ditch, the Wurtz Ditch extension, the Columbine Ditch, the Busk-Ivanhoe Tunnel, the Homestake Project, and the Twin Lakes Project collection system (fig. 15).

The Ewing, Wurtz, and Columbine Ditches are open ditches, conveying water from the headwaters of the Eagle River in the Colorado River basin, through saddles in the Continental Divide into West Tennessee Creek and the East Fork Arkansas River north of Leadville.

The Ewing Ditch is 3/4-mile long, diverting into a tributary of West Tennessee Creek. It intercepts runoff from a drainage area of 2,400 acres. The decree is for 18.5 cubic feet per second, and dates from 1906. Ewing Ditch conveys an average of 1,100 acre-feet of water per year. 


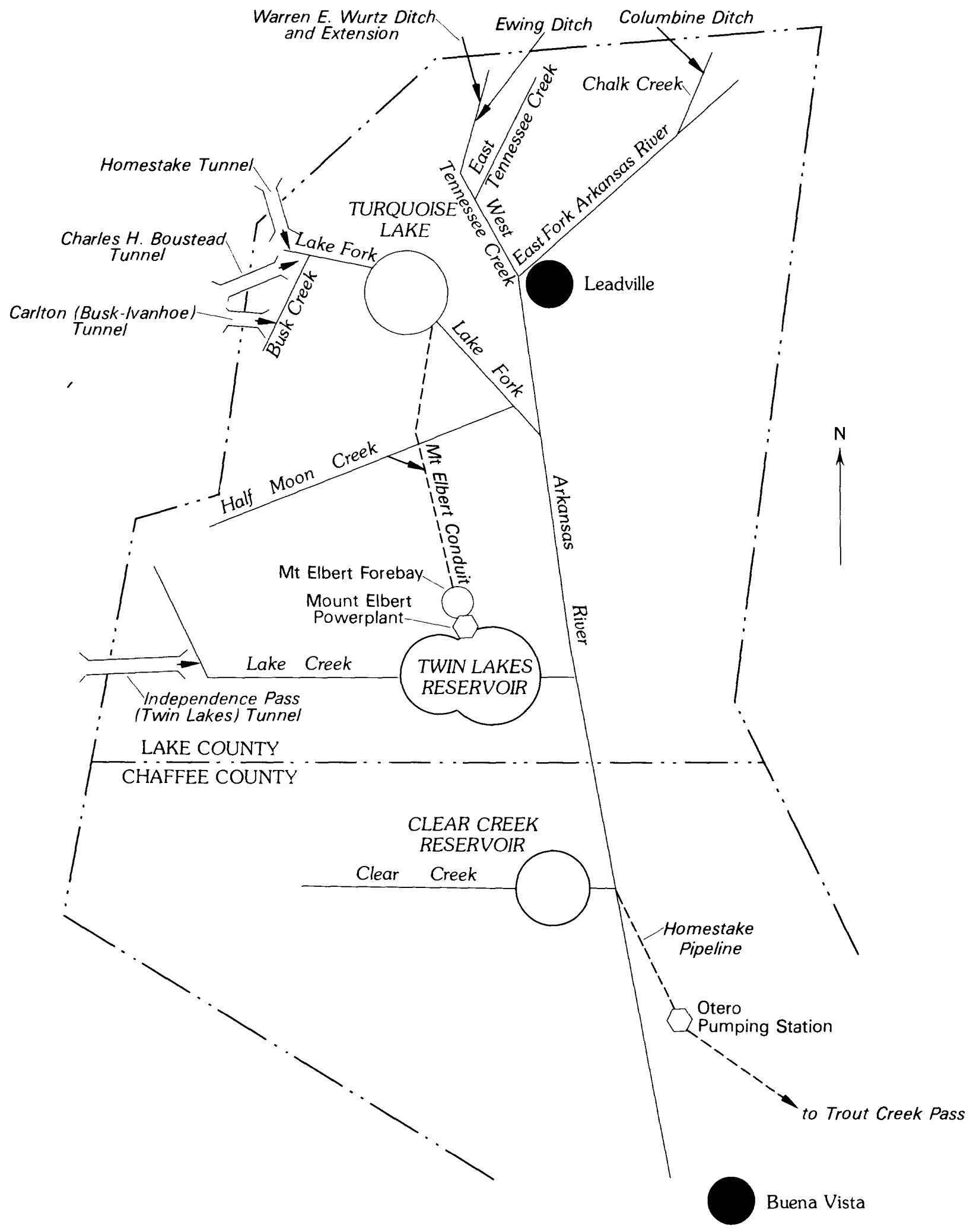

Figure 15.--Pueblo Board of Water Works system and other water development in upper Arkansas River basin, upstream from Buena Vista. 
The Wurtz Ditch is 5 miles long and the Wurtz Ditch extension is another 6 miles long. The ditch and the extension together intercept runoff from a drainage area of 5,840 acres. The decree for Wurtz Ditch is dated 1929, and is for 85 cubic feet per second; the Wurtz Ditch extension decree is dated 1953, and is for 100 cubic feet per second. The Wurtz Ditch empties into West Tennessee Creek. During the past decade, the Wurtz Ditch has conveyed an average of 3,000 acre-feet per year.

The Columbine Ditch intercepts runoff from a drainage area of 1,170 acres in the headwaters of the Eagle River basin and empties into Chalk Creek, a tributary of the East Fork Arkansas River. The Columbine Ditch has a 1930 decree for 60 cubic feet per second. Recent diversions through the Columbine Ditch have been about 1,700 acre-feet per year.

The Busk-Ivanhoe system is owned jointly by the Pueblo Board of Water Works and the Highline Canal Company. Water is diverted from Ivanhoe Creek, a tributary of the Fryingpan River in the Roaring Fork basin to Busk Creek, a Lake Fork tributary, via Carlton (Busk-Ivanhoe) Tunnel. Fryingpan-Arkansas Project's Charles H. Boustead Tunnel also can be used during low-demand periods. The Board realizes an average annual yield of 3,100 acre-feet from the Busk-Ivanhoe system.

The Board is entitled annually and in perpetuity a total of 2,500 acrefeet of Homestake Project water. The Board also has other rights, now held in reserve for future municipal expansion. Waters from these reserve rights continue to be used for the same agricultural purposes that existed prior to acquisition by the Board. These rights include a part of the water from West Pueblo Ditch, the Leadville Ranch (a potential reservoir site, plus a directflow right), and shares of the Twin Lakes Project. The Board also controls 11,476.16 shares of Twin Lakes Project water with a potential yield of 12,624 acre-feet. The Board decides yearly if the water is needed for municipal purposes; otherwise, this water goes to agricultural land supplied by the Colorado Canal Company, that originally owned controlling interests in the Independence Pass (Twin Lakes) Tunnel diversion.

\section{City of Trinidad}

The city of Trinidad obtains its water supply from a collection system located in the mountains about 30 miles west of the city. The collection system consists of two reservoirs, ditches supplying these reservoirs, pipelines from the reservoirs to a filtration plant, and a pipeline from the filtration plant to the city (fig. 16). During 1982, 5,100 acre-feet were supplied to Trinidad water customers.

North Lake, with a decreed capacity of 4,315 acre-feet, receives most of its inflow from North Fork Purgatoire River, through the North Lake inlet, and discharges to the Trinidad filtration plant through the North Lake pipeline. Monument Lake, with a decreed capacity of 1,430 acre-feet, receives water from several sources. Monument Lake ditch No. 1 diverts from North Fork Purgatoire River into the channel of Brown Creek. Downstream from where Monument Lake ditch No. 1 enters, Monument Lake ditch No. 2 diverts from Brown Creek into Monument Lake. The Cherry Creek ditch diverts from Cherry Creek and is joined 


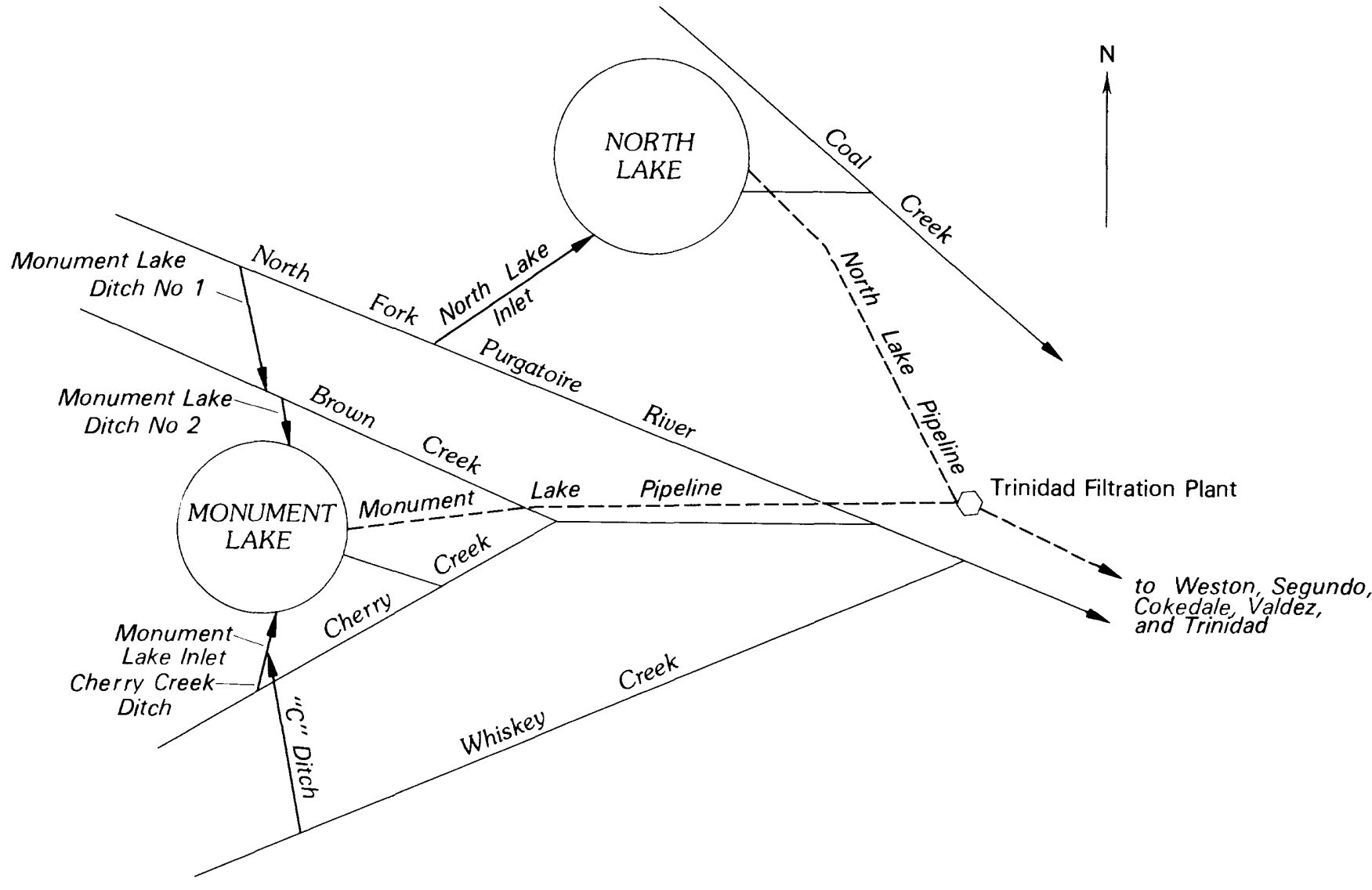

Figure 16.--City of Trinidad mountain collection system.

with the "C" ditch, which diverts from Whiskey Creek to form the Monument Lake inlet that discharges into Monument Lake. Water is conveyed from Monument Lake to the filtration plant in the Monument Lake pipeline.

Usually, only North Lake is used to supply the filtration plant; Monument Lake is held as an emergency reserve. A relative balance of inflow and demand enables North Lake to be maintained with only minor fluctuation of content throughout most of the year.

Trinidad has an option for as much as 7,100 acre-feet per year of Trinidad Dam and Reservoir Project water. To exercise this option would require court action to change from present agricultural use to municipal use; this option is being held in reserve to supply future municipal expansion. 


\section{City of Walsenburg}

The city of Walsenburg obtains its municipal water supply from the Cucharas River and Wahatoya Creek. The 16-inch Walsenburg pipeline diverts water into Wahatoya Lake from the Cucharas River just upstream from the town of La Veta. The Francisco and Daigre (Mi11) ditch diverts water into Wahatoya Lake from both the Cucharas River and Wahatoya Creek. Overflow from Wahatoya Lake, 274 acre-feet capacity, is stored in Daigre Lake, 139 acre-feet (fig. 17). These lakes also are a part of the Wahatoya Colorado State Wildlife Area.

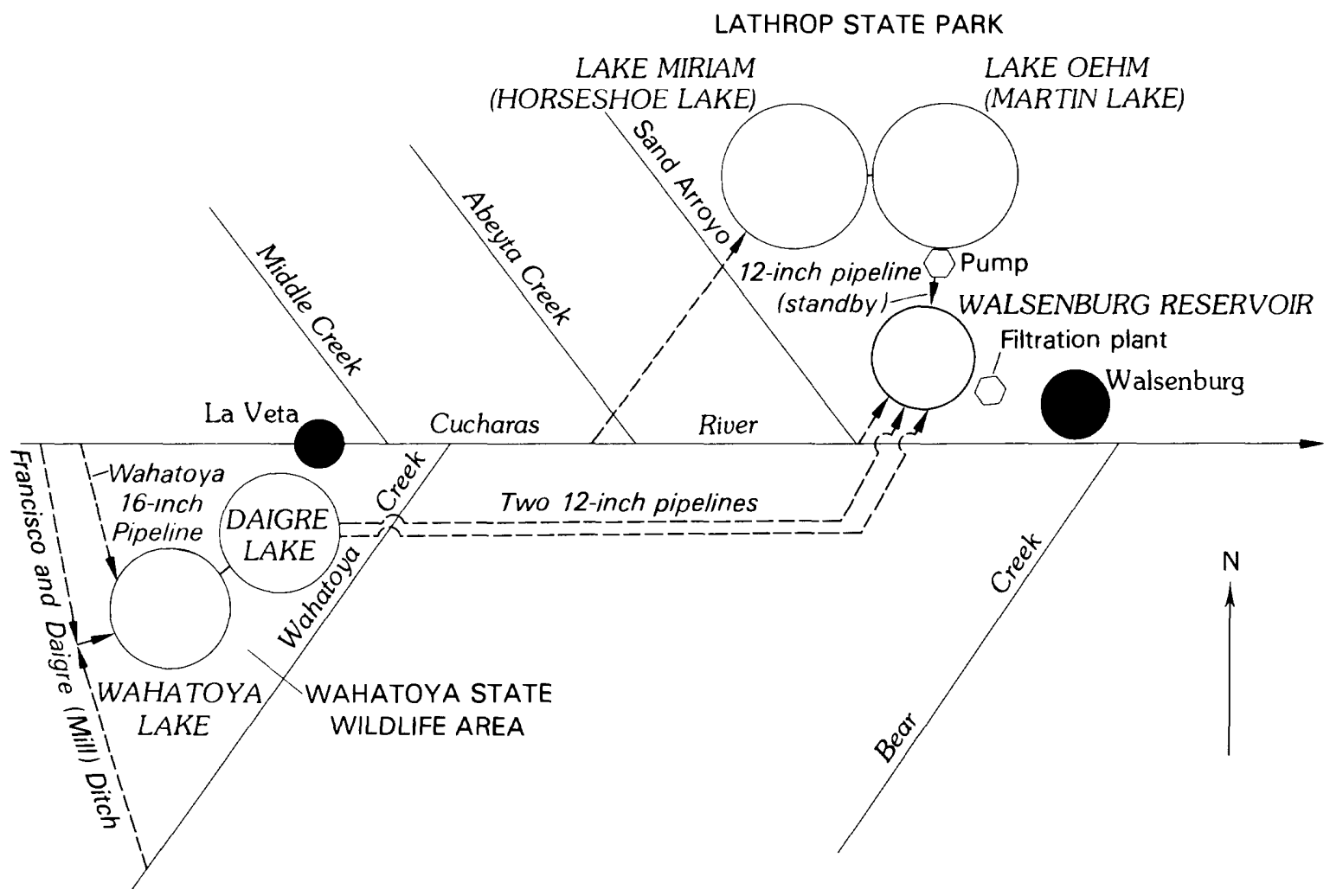

Figure 17.--City of Walsenburg municipal water-supply system. 
From Daigre Lake, water is diverted by two 12-inch pipelines to Walsenburg Reservoir ( 430 acre-feet storage capacity), which is located just south of U.S. Highway 160 , about 3 miles west of town. The Walsenburg filtration plant is located near Walsenburg Reservoir. The city also owns 76.4 percent of the storage rights in Lake Miriam (2,760 acre-feet storage capacity) and in Lake Oehm (4,880 acre-feet storage capacity). These two reservoirs receive water from a ditch that diverts from the Cucharas River. Lake Miriam (Horseshoe Lake) and Lake Oehm (Martin Lake) are in Lathrop State Park, located about 2 miles west of Walsenburg. They also serve as supply for an irrigation ditch. Water can be diverted by pumping through a 12-inch pipeline from Lake Oehm to Walsenburg Reservoir; this is a standby supply and seldom is needed.

\section{EXPLANATION}
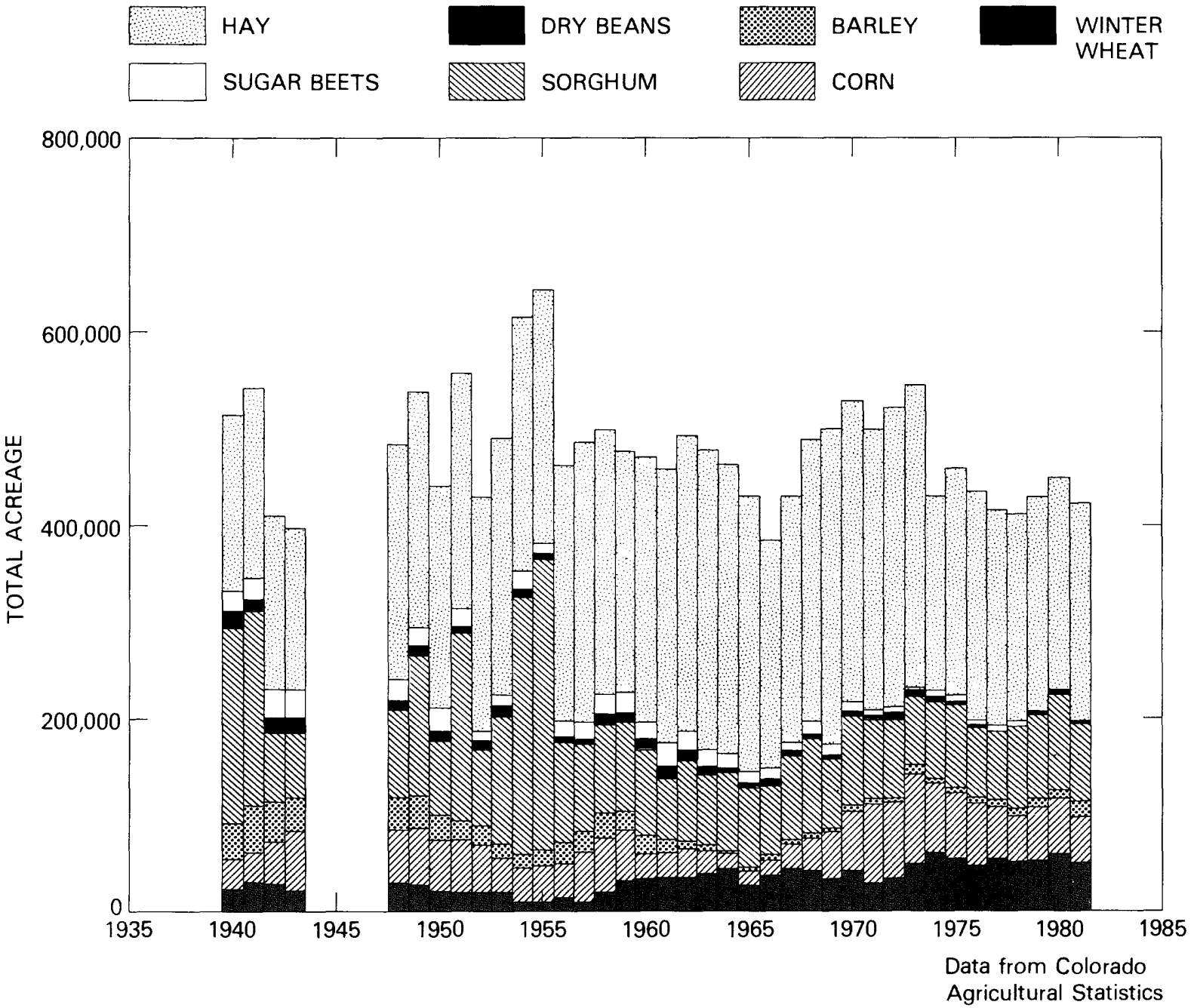

Figure 18.--Acreage of major irrigated crops, other than truck crops. 


\section{Irrigation Systems}

The largest water use in the Arkansas River basin in Colorado is irrigation. Surface water is the principal source of irrigation water; however, there is some use of ground water for irrigation. Irrigation is practiced along almost all major tributaries, where it is used for hay, alfalfa, and irrigated pasture. Alfalfa is the major crop produced on land served by the major ditches in the valley. Other major crops are corn, barley, sorghum, onions, melons, cucumbers, flower seeds, beans, tomatoes, potatoes, irrigated pastures, and wheat. In the past, sugar beets were also a major crop in the Arkansas River valley. Distribution of major crops, other than truck crops, in the Arkansas River basin, 1940-81, is shown in figure 18. Diversions from the Arkansas River for irrigation between Bessemer Ditch headgate and the Colorado-Kansas State line are shown in figure 19.

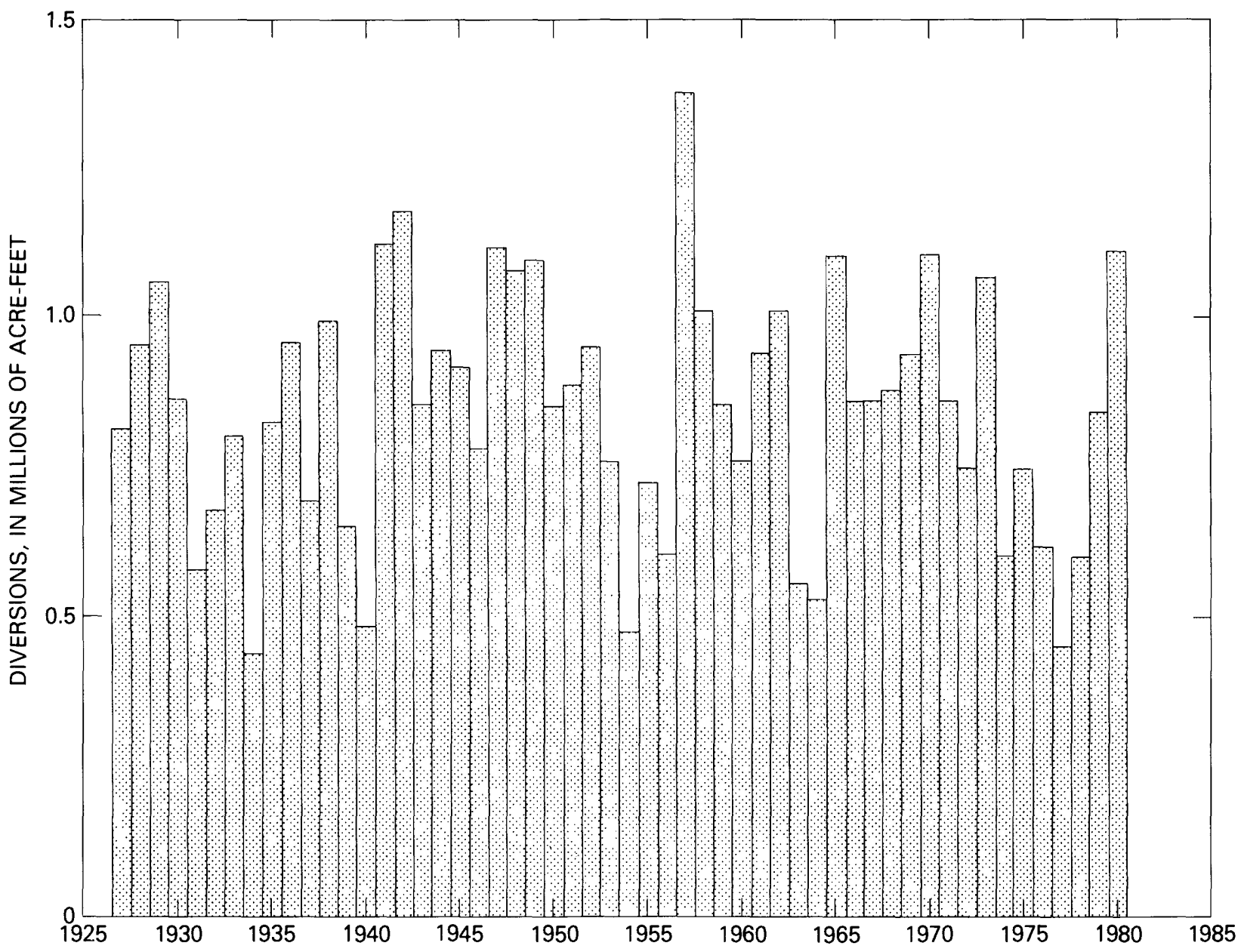

Figure 19.--Annual diversions from the Arkansas River between the Bessemer Ditch headgate and the Colorado-Kansas State line. 
Through the years, the area of land irrigated in the Arkansas Valley has remained relatively stable at about 415,000 acres (U.S. Bureau of Reclamation, 1969), but the seasonal water supply to this area is subject to considerable fluctuations. Waters of the Arkansas River and its tributaries, and water imported into the basin, are used and reused throughout the area.

Storage reservoirs are used throughout the basin. In the upstream reaches of the Arkansas River, and on all of its tributaries, the general practice is for the storage rights and the junior direct-flow rights to store or irrigate very early in the season, later to be called out by senior rights. The river call on the tributaries usually is much senior to the call on the main stem during irrigation seasons of average or low flow.

\section{Arkansas River}

The major irrigation systems along the Arkansas River will be described in this section. The Arkansas River is in Water Districts $11,12,14,17$, and 67 (p1. 1). A schematic diagram of the major irrigation systems along the river is given on plate 3 (in the pocket), and the major water rights are listed in plate 4 (in the pocket). The active ditches and major ditches on the Arkansas River tributaries are listed in table 5 in the Supplemental Data section at the end of the report.

Water from most of the ditches in Water District 11 (Lake and Chaffee Counties) and Water District 12, upstream from the Royal Gorge, is used to irrigate alfalfa, hay, or irrigated pasture. In the Canon City area, the South Canon Ditch diverts water from the south bank just upstream from Grape Creek. This ditch, which splits within the limits of Canon City and becomes the Pump Ditch and the Crooked Ditch, irrigates about 1,280 acres in and near the south side of Canon City. The Canon City Hydraulic Ditch diverts from the north bank just upstream from the streamflow-gaging station 07096000 Arkansas River at Canon City, flows through the grounds of the Colorado State Penitentiary, and on through Canon City. The Fruitland Ditch is supplied from the Canon City Hydraulic Ditch via a buried conduit within Canon City. The Grandview Ditch diverts from the Canon City Hydraulic Ditch at a point just before that ditch wastes into Fourmile Creek near the east edge of town. The Grandview Ditch crosses under U.S. Highway 50 and Fourmile Creek in a buried conduit, and irrigates lands on the State prison farm. In the past, the Fruitland Ditch was diverted, along with Canon City's municipal water, in another ditch, the Canon City Aqueduct. Canon City has abandoned that aqueduct, and now diverts from a new diversion dam in the river, about 3 miles downstream from the old diversion point.

The Canon City and Oil Creek (Mill) Ditch diverts from the north bank just downstream from the Canon City's diversion dam and irrigates about 1,250 acres near the east edge of town. This ditch also receives discharge from the Southern Colorado Power Company's powerplant; the outflow is charged against the Canon City and Oil Creek Ditch's water right.

The Fremont County Ditch diverts from the right bank, midway between Canon City and Florence, irrigating about 425 acres of flood plain. The Union Canal is diverted with the Minnequa Canal and is bifurcated from that canal on 
the west edge of Florence, irrigating about 1,250 acres of 1 and in and east of that town. The Hannenkratt ditch, which diverts from the north bank, irrigates Colorado State Penitentiary land on the flood plain across the river from Florence. The Lester and Atteberry ditch, which diverts from the north bank, irrigates about 180 acres of flood plain east of Florence. Irrigation in the Canon City area serves orchards, some truck crops, and alfalfa.

Major irrigation conveyances diverting from the Arkansas River in Water District 14 are the Bessemer Ditch, Colorado Canal, Highline Canal, and Oxford Farmers Ditch. Smaller irrigation ditches are Hamp-Bel1, West Pueblo, Riverside Dairy, Excelsior, and Collier Ditches. The Bessemer Ditch is diverted through a special outlet in Pueblo Dam. It flows in an open canal through the south side of the city of Pueblo, and through the CF\&I Steel Corporation mill partially in a closed conduit, irrigating about 20,000 acres on the St. Charles mesa, southeast of Pueblo. When the ditch is diverting, it also delivers water to the St. Charles Mesa Water District, a municipal user. The Colorado Canal diverts from the north bank about $3 \frac{1}{2}$ miles upstream from the confluence of the Huerfano River, irrigating about 50,800 acres in Pueblo and Crowley Counties. The Colorado Canal once had exclusive control over the Twin Lakes Reservoir and transmountain diversion system (discussed elsewhere in this report). Irrigators using the canal have sold most of their rights to the transmountain diversion and the storage space in Twin Lakes that formerly regulated those imports to outside interests. The Colorado Canal has two major off-stream storage reservoirs: Lake Henry and Lake Meredith (also known as Bob Creek Reservoir). Water is stored in these reservoirs during the winter. From Lake Henry, the lands irrigated by the Colorado Canal can be irrigated directly by gravity flow. Lake Meredith is topographically too low to irrigate lands by gravity flow. An exchange with the Holbrook Canal, the Fort Lyon Storage Canal, or the Arkansas River is necessary to enable use of Lake Meredith water by users of the Colorado Canal. The Lake Meredith outlet (p1. 3) crosses both canals, before discharging into the river; depending on which canal is in priority at the time, the exchange is made by releasing water through the outlet into the receiving channel, and diverting a like quantity at the Colorado Canal headgate. To accomplish this exchange, sufficient water must be left in the river at the Colorado headgate to satisfy all senior rights downstream between the headgate and either the outlet canal or the headgate of the canal with which the exchange is being made. Water can be delivered from Lake Henry into Lake Meredith.

The Highline Canal Company has rights to divert not only native water from the Arkansas River, but also is part owner with the Pueblo Board of Water Works, of the Busk-Ivanhoe transmountain diversion. Highline Canal Company has a contract with the Fryingpan-Arkansas Project to store imported water in that project's Turquoise Lake. Transmountain water is used to supplement direct diversions, and to maintain an even-flowing ditch during irrigation season. The Highline Canal diverts from the south bank at a point just downstream from the Huerfano River, irrigating 26,000 acres in Pueblo and Otero Counties.

The Oxford Farmers Ditch diverts from the south side of the river at a point about 5 miles downstream from the mouth of the Huerfano River, irrigating about 6,000 acres of land in Pueblo and Otero County. 
The Otero, Catlin, Holbrook, Fort Lyon Storage, Rocky Ford, Fort Lyon, and Las Animas Consolidated Canals headgates are all in Water District 17. The Otero Canal diverts from the south side of the river at a point about 6 miles upstream from the mouth of the Apishapa River. This canal is siphoned under the Apishapa River and irrigates about 10,000 acres in Otero County.

The Catlin Canal diverts from the south side of the river just downstream from the confluence of the Apishapa River, irrigating about 18,800 acres on the south side of the Apishapa River near Manzanola and Rocky Ford. The Catlin Canal Company owns the Larkspur transmountain diversion, and part of Wright's or Mount Pisgah Reservoir on Fourmile or Oil Creek. The Catlin Canal Company usually stores its transmountain diversions by exchange in space, leased in the Fryingpan-Arkansas Project system.

Holbrook Canal diverts from the north bank a short distance downstream from the State Highway 207 bridge near Manzanola. Exchange water from Lake Meredith can be released into Holbrook Canal. From the Holbrook Canal, water can be stored in the 7,986-acre-foot Dye Reservoir, or the 7,472-acre-foot Holbrook Reservoir. Neither reservoir normally can release water directly to the land, but must rely on an exchange with the river. The Rocky Ford Ditch is the main water right considered in this exchange. The Holbrook Canal irrigates 19,550 acres of land, and wastewater flows into Horse Creek. Cheraw Lake is filled by seepage and local drainage, and is not used to irrigate lands.

The Rocky Ford Canal diverts from the south bank at a point about midway between the towns of Manzanola and Rocky Ford. Water rights in this canal are very early water rights and are in priority most of the time. This canal maintains an even flow by using a self-adjusting wasteway gate, just upstream from the measuring section, which is located about 1 mile downditch from the headgage, and some water is diverted around the Fort Lyon Storage Canal diversion dam in this manner. The Rocky Ford Canal irrigates about 8,200 acres, in and near the town of Rocky Ford; until recently, a part of the diversions of the Rocky Ford Canal was industrial water for a now-defunct sugar factory.

The Fort Lyon Storage Canal headgate is located about 1 mile downstream from the Holbrook Canal headgate. The Fort Lyon Storage Canal delivers water to Horse Creek Reservoir and to Adobe Creek Reservoir. Horse Creek Reservoir, 28,000 acre-feet, also has a storage right to the waters of Horse Creek, and can deliver irrigation water directly to the Fort Lyon Canal. Adobe Creek Reservoir, 85,000 acre-feet, also has a storage right to waters from Adobe Creek. Releases from Adobe Creek Reservoir go down the channel of Adobe Creek directly into the Fort Lyon Canal. The Fort Lyon Storage Canal can receive exchange water from the Lake Meredith Outlet Canal.

The Fort Lyon Canal diverts from the north side of the river about midway between Swink and La Junta. It can receive water from Horse Creek and Adobe Creek Reservoirs, as well as from the creeks for which those reservoirs were named. Downcanal from Adobe Creek, water can be delivered to the Kicking Bird Canal for storage in the Great Plains Reservoir system (discussed later under the Amity Canal). 
Tailwater from the Fort Lyon Canal either can flow directly into the 2,500-acre-foot Thurston Reservoir, or can collect in an unnamed reservoir at the end of the canal. From Thurston Reservoir, an exchange is possible with the Amity Canal, through the West May Valley Drainage Ditch. The Fort Lyons Canal is divided into five divisions; each division receives irrigation water in turn. The Fort Lyon Canal receives a share of the Amity Canal's Great Plains water, as part of the arrangement whereby the Fort Lyon Canal is used to deliver water to the Kicking Bird Canal. Water from the Fort Lyon Canal irrigates about 91,300 acres in Crowley, Bent, and Prowers Counties.

The Las Animas Consolidated Canal diverts from the south side of the river, about 8 miles upstream from Las Animas. The Las Animas Consolidated Canal becomes the Las Animas Consolidated Extension, a ditch on the east side of the Purgatoire River. Water can be delivered from the Highland Ditch, which diverts from the Purgatoire River upstream from Las Animas into the Las Animas Consolidated Canal. The combined acreage irrigated by this system is about 6,950 acres, with 2,300 of these acres irrigated by the Las Animas Consolidated Extension. The headgate of the Las Animas Town Ditch was 4 miles downstream from the Consolidated Canal before the 1965 flood; water rights were transferred to Las Animas Consolidated Canal in March 1966. In April 1972, the Las Animas Town Ditch water rights were acquired by the Highline Canal, and were transferred to the Highline Canal headgate.

All of the canal and ditch systems on the Arkansas River downstream from John Martin Reservoir are in Water District 67; all these systems participate in the Arkansas River Compact. These systems, and systems in Kansas, store winter and excess streamflows in John Martin Reservoir for later use.

The Fort Bent Canal and the Keese ditch share a common diversion dam on

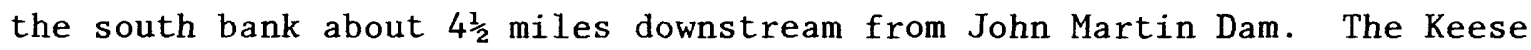
ditch diverts out of the Fort Bent Canal, just downcanal from the headgate, irrigating the flood plain west of Lamar. The Fort Bent Canal flows through the city of Lamar, and irrigates lands both west and east of town. Water also is conveyed in the Fort Bent Canal to recharge the city of Lamar's well field in Clay Creek. The combined area irrigated by the Fort Bent Canal and the Keese ditch is 8,740 acres.

The Amity Canal diverts from the north bank about 8 miles downstream from John Martin Dam and irrigates about 37,800 acres. The Great Plains Reservoirs [the Nee So Pah (Black Water), the Nee No She (Standing Water), the Nee Gronda (Big Water), and the Nee Skah (Queens) Reservoirs] are a part of the Amity system. They have a total capacity of 265,552 acre-feet and are connected to the Amity Canal by the Comanche Canal. These reservoirs are broad, shallow lakes, and the surface-area-to-capacity ratio allows significant evaporation. A large, dead-storage pool in the system permits considerably more stored water than can be withdrawn; therefore, storage for the Amity Canal is in John Martin Reservoir, instead of in the Great Plains Reservoirs whenever possible.

The Lamar Canal diverts from the south bank, just at the west edge of Lamar, irrigating about 8,700 acres east of town. The city of Lamar powerplant has a battery of wells for cooling water that discharges directly into the Lamar Canal, and this discharge is measured and charged to the Lamar Canal decree. 
The Hyde ditch has recently changed its point of diversion from the headgate on the north bank just opposite the city of Lamar, to a point on the canal about 2 miles downditch from the old headgate. Water from the Arkansas River is pumped to the Hyde Canal at the new point of diversion, and the western part of the ditch is maintained to intercept the West May Valley Drainage Ditch. The Hyde ditch irrigates about 970 acres west of Big Sandy Creek.

The Manvel ditch irrigates about 750 acres on the south side of the river, from a headgate located about 7 miles downstream from Lamar. The Manvel ditch has been unable to divert through its headgate under normal conditions since the 1965 flood. The canal operates from wells, some seepage, and Arkansas River Compact storage water. Storage water is delivered through the Lamar Canal.

The X-Y Canal and Graham Ditch share a common ditch and headgate, about 4 miles downstream from the Manvel ditch headgate, irrigating about 6,000 acres on the south side of the Arkansas River. In recent years, the Graham water right has been transferred to the exclusive use of wells.

The Buffalo Canal diverts from the north bank, irrigating about 5,000 acres of land around Holly. The Buffalo Canal also has rights to divert out of Buffalo Creek. The Holly Drain drains land irrigated by the Buffalo Canal. The Sisson Ditch no longer irrigates with surface water; all rights of this ditch have been transferred to wells. The Frontier ditch, although its headgate is located in Colorado, irrigates land in Kansas, and is considered a Kansas ditch.

\section{Arkansas River Tributaries}

The raising of stock feed is the major use of irrigation on the Arkansas River basin tributaries. Alfalfa is perhaps the most common crop, followed by irrigated pasture, hay, and small grains. Surface water is the largest source of irrigation supply; but, with the advent of center-pivot sprinklers, some ground water is beginning to be used for irrigation.

Wet Mountain Valley

The Wet Mountain Valley, located in Custer and Fremont Counties between the Wet Mountains and the Sangre de Cristo Range, is drained by Grape and Texas Creeks. The drainage basins of those creeks comprise Colorado Water District 13 .

Lake DeWeese (DeWeese-Dye Reservoir) is located on Grape Creek at the downstream end of the irrigated area. It regulates the irrigation supply of the DeWeese-Dye ditch, which diverts from the east bank of Grape Creek near the mouth, and irrigates orchard, truck crops, and alfalfa in and near Canon City.

Fourmile, Hardscrabble, and Beaver Creeks

The Canon Heights Irrigation Company uses five small reservoirs located on the north side of Canon City that receive water from Fourmile Creek through the Park Center Ditch. Canon Heights Irrigation Company also controls oneseventh of Mount Pisgah Reservoir storage, with rights to the use of water from a nontributary flowing well. The Hardscrabble ditch on Hardscrabble Creek is the oldest water right in Water District 12, dating from May 1, 1860. 
The Beaver Park Irrigation Company irrigates land around Penrose with water from Brush Hollow Reservoir, and with direct flow from Beaver Creek. Brush Hollow Reservoir, 4,125 acre-feet, stores water from Brush Hollow Creek, and is supplied from Beaver Creek through the Brush Hollow Supply Ditch and conduit. The Beaver Park Irrigation Company has recently acquired the right for storage in the top 2 feet of Skagway Reservoir. Skagway Reservoir, 3,678 acre-feet, was originally a hydroelectric power forebay; in recent years, it has been operated for recreation uses by the Colorado Department of Fish and Wildlife.

\section{Fountain Creek}

Fountain Creek is in Water District 10. Most irrigation systems diverting from Fountain Creek irrigate fields located on the flood plain of that creek, or the flood plain at the downstream end of major tributaries to Fountain Creek. Two larger systems serving terrace lands outside the flood plain in El Paso County are the Fountain Mutual ditch and the Chilicott Canal. The Fountain Mutual ditch diverts from the east bank, in the city of Colorado Springs, irrigating about 3,850 acres in and around the communities of Security, Widefield, and Fountain. The Fountain Mutual ditch stores water in the 3,950-acre-foot Big Johnson Reservoir (Fountain Valley Reservoir 2). Little Johnson Reservoir (Fountain Valley Reservoir 3), 682 acre-feet, is no longer used to regulate Fountain Mutual irrigation water, but will be used as a recharge pond for ground-water recharge. Upstream from Big Johnson Reservoir, the Fountain Mutual ditch is known as Ditch 4; downditch from the reservoir, it is called the Fountain ditch.

The Chilicott Canal diverts from the east bank, about midway between the towns of Widefield and Fountain. The ditch is siphoned under Jimmy Camp Creek and irrigates about 3,000 acres. Irrigation supply is regulated in the 347-acre-foot Callahan Reservoir.

St. Charles River

The main tributary of the St. Charles River, Greenhorn Creek, is the location of the earliest priority in the Arkansas River basin: the Hicklin ditch, with a water right from spring 1859. The St. Charles River basin comprises Water District 15. Reservoirs in the basin are for recreation and industrial purposes, although some incidental irrigation from some reservoirs is practiced.

\section{Huerfano River}

The Huerfano River basin is within three water districts: (1) The downstream end, approximately that part in Pueblo County, is in Water District 14; (2) the upstream end is in Water District 79; and (3) the basin of the Cucharas River is in Water District 16. The Cucharas River basin is discussed in a subsequent part of the report. A transmountain diversion occurs at the headwaters of the Huerfano River. Medano Ditch conveys waters of Medano Creek in the San Luis Valley (Rio Grande basin) into Hudson Branch of South Muddy Creek in the Huerfano River basin. The Medano water imports are stored by exchange in Wolf, Roach, and Creager Reservoirs, and are used for irrigation on a large ranch. The flood plain of the Huerfano River, from Redwing east, is wide and irrigated. There is irrigation using the flows of the major tributaries in the upstream end of the Huerfano Valley, especially Pass, Williams, and Turkey Creeks. Ditches with direct-flow rights, dating from June 1869 or 
earlier, are usually in priority throughout the irrigation season; ditches with later priorities divert early in the season, and during high flow.

Orlando Reservoir, with storage rights totaling 4,350 acre-feet, receives water from the Orlando Ditch, which diverts water from the north bank about one-half mile upstream from Interstate Highway 25. Stored water can be released back into the Huerfano River and used on irrigated bottom lands. A broad area, located north of the Huerfano River and east of the Wet Mountains, is irrigated by the waters of Apache Creek. Clark Reservoir No. 1 receives water from a ditch, which diverts from the south bank of the Apache Creek just west of Interstate Highway 25.

The Huerfano Valley ditch diverts water to the 2,088 acre-foot Huerfano Valley Reservoir from which about 1,000 acres north of the river in Pueblo County is irrigated. The Huerfano Valley ditch receives the waters stored in Cucharas Reservoir.

The Farmers Nepesta ditch diverts from the east bank, about 15 miles upstream from the mouth of the Huerfano River. It irrigates about 350 acres and regulates water in the 2,500-acre-foot Dotson Reservoir, and in the Nepesta Reservoir No. 5.

The Welton Ditch irrigates about 1,500 acres south and east of the Huerfano River in Pueblo County. During most years, the Huerfano River is dry downstream from the Weldon Ditch headgate.

Cucharas River

Major tributaries of the Cucharas River that supply water for irrigation are Middle Creek, Wahatoya Creek, Abeyta Creek, Bear Creek, and Santa Clara Creek. Reservoirs supplied from the Cucharas River (Water District 16) include municipal-supply reservoirs, such as the La Veta Town Reservoir, and the reservoirs of Wahatoya, Daigre, and Walsenburg (see fig. 17). Reservoirs, originally developed for irrigation supply, are today partially used for recreation, such as the 1,148 acre-foot Lake Miriam (Horseshoe Lake), and the 2,573-acre-foot Lake Oehm (Martin Lake), which are now in Lathrop State Park. Other irrigation reservoirs used primarily for recreation are the now-combined Maria and Stevens Reservoirs, east of Walsenburg, which are now a private game and fish reserve.

A number of reservoirs are still in use to regulate irrigation supply in the basin. The Sharps Orchard Reservoir ( 84 acre-feet of storage) and La Joya Reservoir (177 acre-feet of storage), receive water from the Cucharas River by the Gomez Ditch. The Holita Reservoir, 540 acre-feet, receives its supply from the Cucharas River through the Walsenburg ditch. The Arnold Flood Reservoir, 80 acre-feet, the Sunnyside Reservoir, 120 acre-feet, and the Saliba (Antonio D. Valdez) Reservoir, 4,858 acre-feet, are all supplied from Santa Clara Creek. Salas Reservoir, 14 acre-feet, in the Bear Creek basin is supplied by that creek. Cucharas Valley Reservoir, 40,960 acre-feet, is located on the channel of the Cucharas River at the downstream end of the basin. This reservoir stores irrigation water for the Huerfano Valley ditch, located downstream on the Huerfano River. 
Apishapa River

The Apishapa River basin upstream from Tejana Arroyo forms Water District 18. During most years, the Apishapa River is dry downstream from the Escondito ditch, which serves the Hidden Valley Ranch at the downstream end of the district. Just upstream from the Escondito ditch is the 4,766-acre-foot Seven Lakes Reservoir, the only reservoir in the district with a storage right. During the $1920^{\prime} \mathrm{s}$, a flood moved the channel of the Apishapa River away from the inlet of the Seven Lakes Reservoir and from the headgates of a number of ditches in the area. Many ditch owners have filed for new points of diversion and have re-established their rights; the Salisbury and Widderfield ditches, east of Aguilar, are examples of these re-established headgates.

Irrigators with water rights, dating from 1867 or earlier, are in priority throughout most of the irrigation season. Irrigators with junior rights obtain their water very early in the season, or during the occasional periods of greater-than-average flow.

\section{Purgatoire River}

The Purgatoire River basin is in Water Districts 17 and 19; the boundary line between the districts is the Las Animas-Otero County line. In the upstream reaches of the basin, Russell Lake, 200 acre-feet, is used to regulate irrigation water; Monument and North Lakes are water-supply reservoirs for the city of Trinidad (described elsewhere in this report).

Upstream from Trinidad Lake, which is located 3 miles upstream from the city of Trinidad, most irrigation is for lands adjacent to the narrow flood plain of the Purgatoire River. The principal area of irrigation in the Purgatoire River basin is located just east and downstream from Trinidad. Ditches in this area are part of the Purgatoire River Conservancy District and receive water from the Trinidad Project (described elsewhere in this report). Those ditches (fig. 20) are the Chilili Ditch, the Enlarged Southside ditch (which conveys water to the Victor Florez ditch), and the Lewelling-McCormick Ditch, all of which divert from the south bank of the Purgatoire River just downstream from Trinidad. Ditches in this area, diverting from the north side of the river, are the Baca-Joint ditch (also known as the Picketwire Ditch); the El Moro ditch; the Model Inlet Canal, from which water is diverted to the Johns Flood Canal; the Hoehne Ditch; and the Salas ditch. Upstream from the Salas ditch, the Burns and Duncan Ditch is supplied by pumping water from the Purgatoire River. Present operations of these canals are discussed in the section describing the Trinidad Dam and Reservoir Project elsewhere in this report.

Major tributaries downstream from the city of Trinidad, from which irrigation diversions are made, include Luning Arroyo, Chicosa Arroyo, Grey Creek, Frijole Creek, San Francisco Creek, San Ysidro Creek, and Trinchera Creek. A number of storage rights regulate irrigation supplies on the plains east of Trinidad. Some of the larger of these storage rights are the Hermosa Valley Reservoir, 1,000 acre-feet, supplied from San Francisco Creek; Brown Reservoir No. 1, 180 acre-feet, diverting from Van Bremer Arroyo, and Johns Reservoir, 395 acre-feet, supplied by the Baca-Joint (Picketwire) ditch. The storage right for the Model Reservoir, 20,000 acre-feet, has been transferred to Trinidad Reservoir. A new, very junior, storage right has been decreed at the site of Model Reservoir. The distribution system of the Model Outlet Canal 


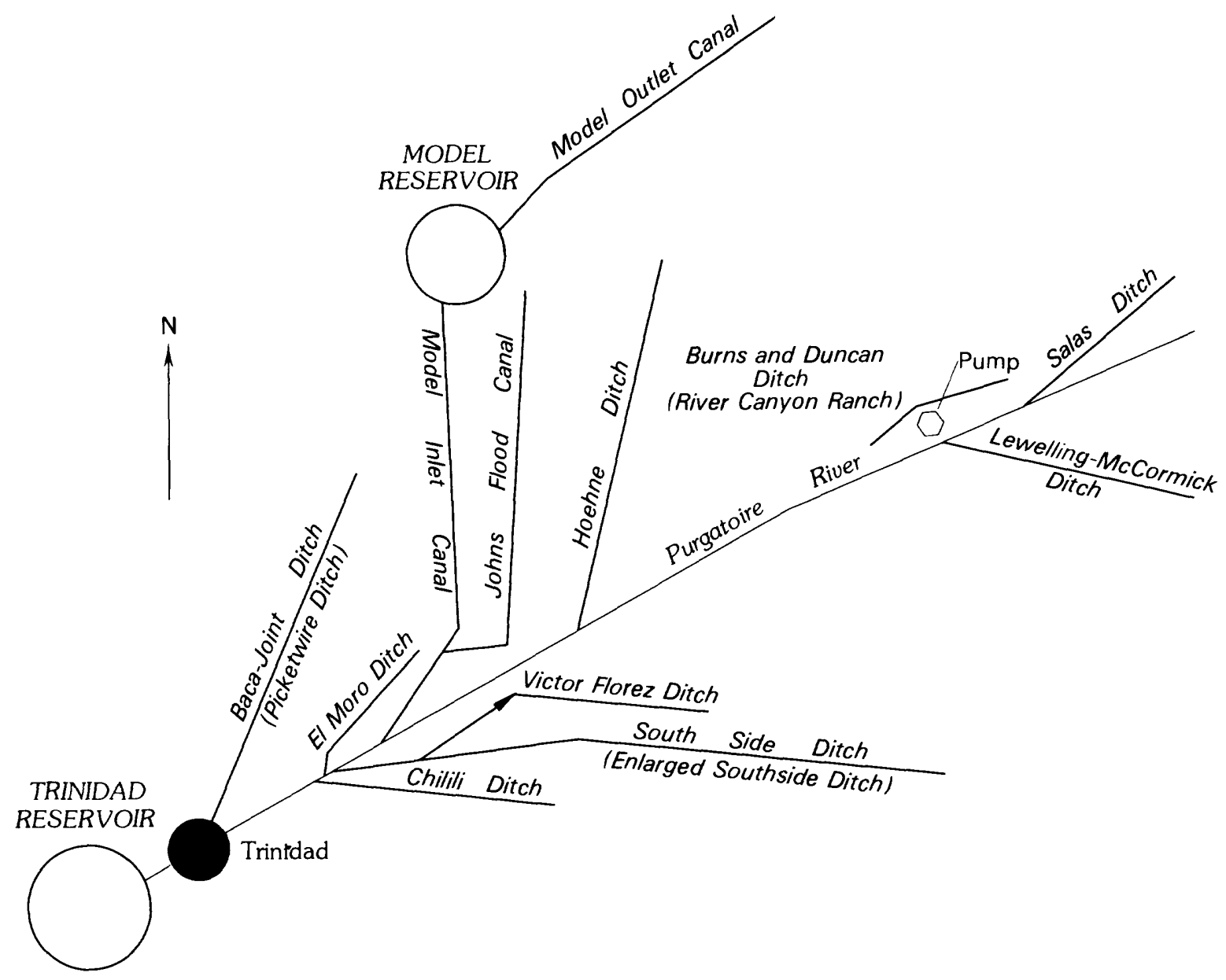

Figure 20.--Ditch systems in the irrigated area of the Trinidad Dam and Reservoir Project.

recently has been improved, and the water now is delivered to the field in underground pipes, allowing more efficient coverage with the existing water supply. Winter wheat is the principal crop being grown with water from the new system. Downstream from the area irrigated by the Trinidad Dam and Reservoir Project, the river enters the 65-mile Purgatoire Canyon.

Two major ditches divert from the river downstream from Purgatoire Canyon in Otero and Bent Counties: the Ninemile and the Highland Canals. Both irrigate lands on the west side of the river. Highland Canal water rights are senior to Ninemile Canal water rights; however, by a court decision, Ninemile Canal is not obligated to pass flows smaller than certain limits to the Highland Canal. The limits below which the call is considered to be a futile call ranges from 3 cubic feet per second in the winter to 8 cubic feet per second in the summer. 


\section{Industrial System: CF\&I Steel Corporation}

The CF\&I Steel Corporation (CF\&I), formerly Colorado Fuel and Iron Corporation, is the largest industrial user of Arkansas River basin water in Colorado. CF\&I annually diverts between 80,000 and 110,000 acre-feet (a continuous supply is required) for use in their Pueblo plant. Less than 20 percent of diverted water is consumed; the rest is returned to the river. Formerly, the major uses of the water by CF\&I were steam production and cooling (Adkins, 1962). Currently (1983) power is purchased from an outside source, and cooling is the primary water use. To assure an adequate supply, CF\&I acquired some of the earliest water rights in the basin, including direct-flow rights from the Arkansas and St. Charles Rivers, plus storage rights in the upper basin. CF\&I also has water rights in the Purgatoire River basin for use in coal-mining operations.

CF\&I's upstream storage right is 27,416 acre-feet in Turquoise Lake (behind Sugar Loaf Dam) near Leadville (a part of the U.S. Bureau of Reclamation's Fryingpan-Arkansas Project) (fig. 15). Turquoise Lake is an enlargement of a 17,416-acre-foot reservoir formerly owned by CF\&I; the corporation also held conditional decrees for a planned enlargement of the lake. As a condition of the acquisition of the site by the U.S. Bureau of Reclamation, CF\&I retained 17,416 acre-feet of storage space in the enlarged reservoir, and an option, since exercised, to lease an additional 10,000 acre-feet. Water stored in this space is from water rights CF\&I holds on Lake Fork, Tennessee Fork, and East Fork. Water from the last two streams are stored in Turquoise Reservoir by exchange.

Three regulating reservoirs, with a combined storage of about 12,730 acre-feet, are located in the drainage basin of Salt Creek, located west and southwest of Pueblo (fig. 21). These reservoirs receive water from the Arkansas River through the Minnequa Canal, and from the St. Charles River by the St. Charles Flood Ditch. Lake Minnequa (Reservoir No. 1) has a capacity of about 1,380 acre-feet and the water must be pumped to the plant. Currently (1983), Lake Minnequa is used only as a standby emergency supply. Reservoir No. 2 and Reservoir No. 3 are connected by four 30 -inch pipes and water from Reservoir No. 2 is conveyed by gravity flow to the mill through two covered conduits.

The 46-mile long Minnequa Canal diverts water from the Arkansas River at a point 3 miles west of Florence. The Union Ditch receives water from the Minnequa Canal near the west edge of Florence, and supplies local irrigation. Eleven waste gates are located along the canal. Constructed in 1942-43 to replace a less efficient system dating from 1907, the Minnequa Canal has a capacity of 286 cubic feet per second and is the source of about 85 percent of the plant supply.

The St. Charles Flood Ditch diverts from the St. Charles River at a point 13 miles southwest of the plant. The capacity of the St. Charles Flood Ditch is 625 cubic feet per second and supplies the other 15 percent of the plant's water requirement. Wastewater from all plant uses is treated and returned to the Arkansas River by way of Salt Creek. 


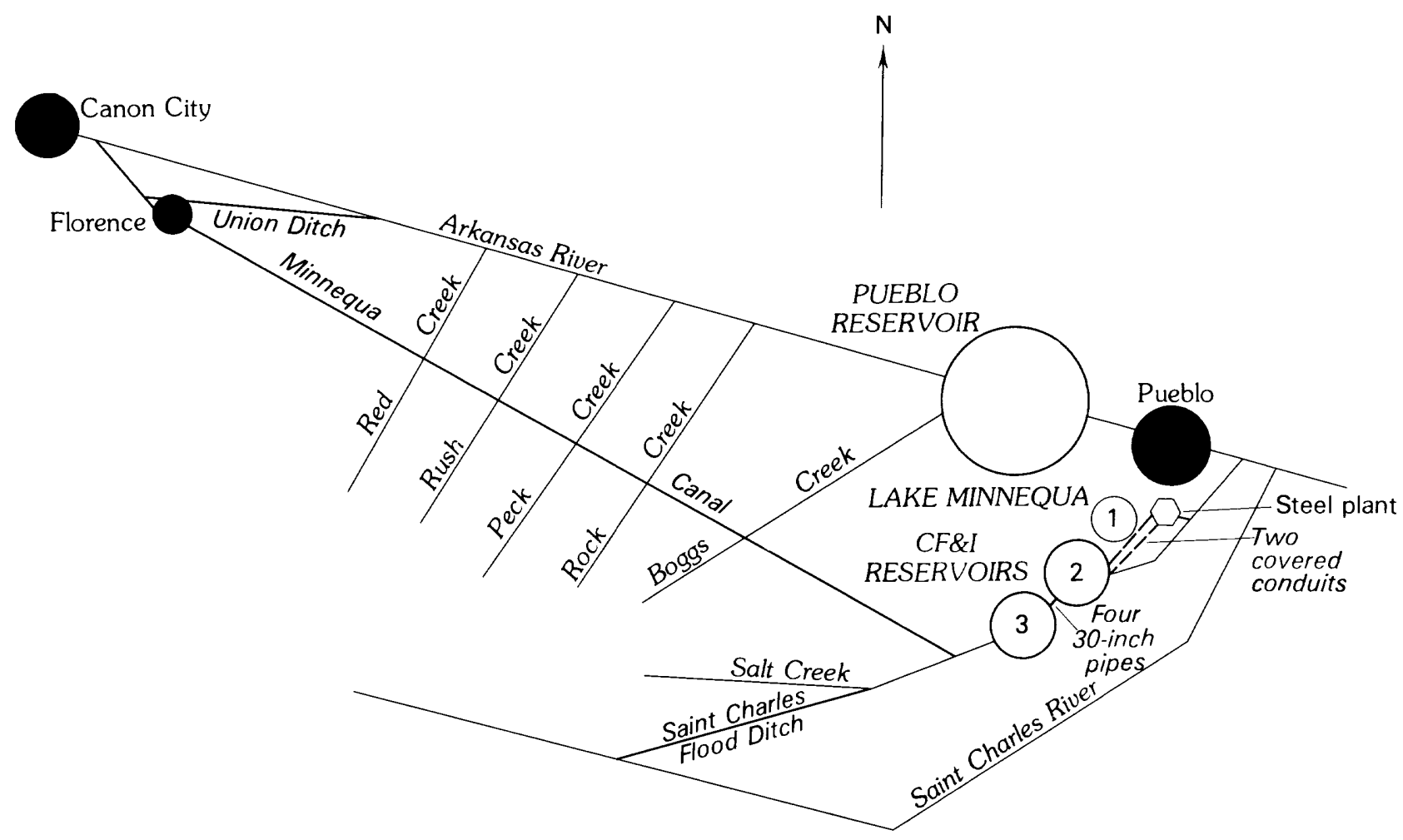

Figure 21.--CF\&I Steel Corporation's near-plant water-supply system. 
The preceding summary describes water operations of CF\&I Steel Corporation during about the last 75 years; this discussion is necessary to interpret the record of flow in the Arkansas River during that period. Beginning in late 1983, CF\&I began to decrease production because of a decrease in steel prices and began to divest itself of much of its land and water holdings. Five thousand acre-feet of storage space in Turquoise Lake has been sold to the city of Aurora; additional space and water rights are currently (1983) on the market, and more are expected to be offered for sale in the future.

\section{Multipurpose Systems}

Three Federal projects and one former irrigation project, which is being transformed into multipurpose use, are located in the Arkansas River basin. The Fryingpan-Arkansas Project, built by the U.S. Bureau of Reclamation, is a storage and transmountain-diversion project, regulating agricultural water supplies, municipal water supplies, and industrial water supplies. This project also contains a flood-control pool in Pueblo Reservoir, and recreation uses in all project lakes. The other two Federal projects, John Martin Dam (see discussion of the Arkansas River Compact) and the Trinidad Dam and Reservoir Project, are primarily flood-control projects constructed by the U.S. Army Corps of Engineers. These projects also regulate irrigation water supplies, and contain recreation pools. The Twin Lakes Project is a storage and transmountain-diversion project that formerly was used only as an irrigation supply for lands irrigated by water from the Colorado Canal. In the late 1970's, ownership passed to more diversified interests, and Twin Lakes Project water now (1983) is used for multiple purposes.

\section{Fryingpan-Arkansas Project}

The Fryingpan-Arkansas Project is a multipurpose water development constructed by the U.S. Bureau of Reclamation. The project was authorized by the U.S. Congress on August 16, 1962; construction began in 1963, and virtually was complete by 1980 . The chief purpose of the project is to divert unappropriated water from the western slope of Colorado for use on the more populated and water-short eastern slope. An annual average of 69,200 acre-feet, plus 3,000 acre-feet of water to be exchanged with the Twin Lakes Project, can be diverted.

The North and South Side Collection Systems (fig. 22) divert water from the headwater tributaries of Hunter Creek and the Fryingpan River, both tributaries of the Roaring Fork River in the Colorado River basin, into the Lake Fork Arkansas River via Charles H. Boustead Tunnel. Project features located in the upstream reaches of the Arkansas River basin (fig. 15) include Turquoise Lake (behind Sugar Loaf Dam), Mount Elbert conduit, Mount Elbert forebay, Mount Elbert pumped-storage powerplant, Twin Lakes Reservoir, Pueblo Reservoir, and Fountain Valley pipeline (p1. 1). Ruedi Reservoir, located on the Fryingpan River downstream from the North and South Side Collection System, serves as replacement storage for the project. 


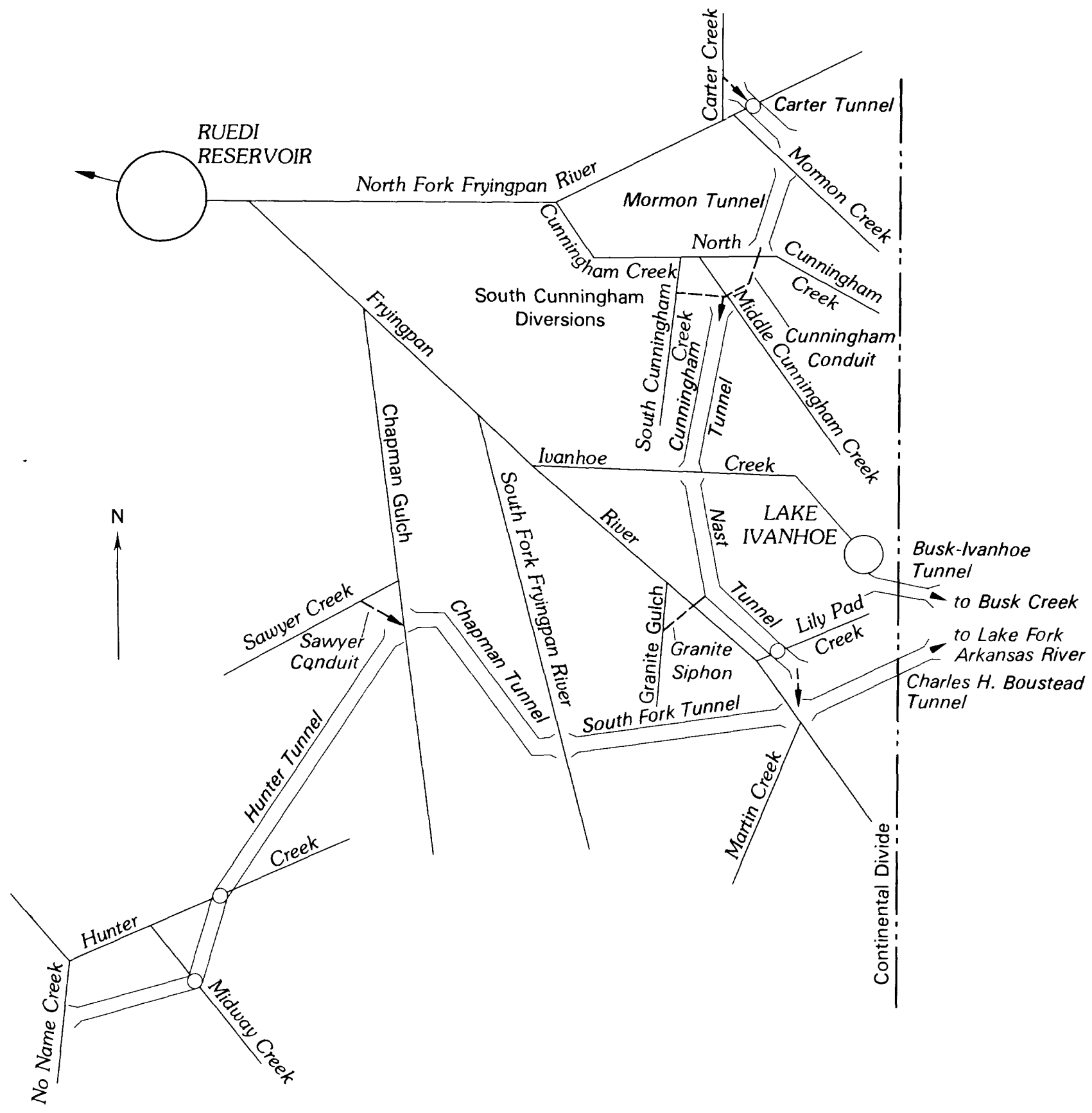

Figure 22.--North and South Side Collection System, Fryingpan-Arkansas Project. 
Water imported through Charles H. Boustead Tunnel, along with BuskIvanhoe Tunnel imports, Homestake Tunnel imports, and native water stored by CF\&I and other entities owning or leasing storage space, are regulated in Turquoise Lake. Turquoise Lake, located 5 miles west of Leadville is the uppermost storage facility in the system. It is planned that water will be held as far upstream in the system as possible for as long as possible. Turquoise Lake should be at a low level early in the spring, before the mountain snowpack starts to melt; be filled to the annual maximum content near the end of July; and then steadily be drawn down throughout the remainder of the year, reaching a minimum content near the end of the following April. Releases from Turquoise Lake, greater than minimum-flow requirements and irrigation-diversion rights upstream from the mouth of Lake Creek, will be diverted through the Mount Elbert conduit. Halfmoon Creek also can be diverted partially into the Mount Elbert conduit. This conduit delivers water to the Mount Elbert forebay from which it goes through the Mount Elbert pumped-storage powerplant and into Twin Lakes Reservoir. Mount Elbert forebay is an 11,530-acre-foot reservoir, located just north, and about 475 feet above, Mount Elbert pumped-storage powerplant. The forebay delivers water to the powerplant through two 15-foot diameter penstocks. The Mount Elbert pumped-storage powerplant, on the north shore of Twin Lakes Reservoir, has a designed capacity of 200 megawatts. Twin Lakes Reservoir has a total storage capacity of 140,339 acre-feet, of which only 67,833 acre-feet is active.

The Mount Elbert pumped-storage powerplant is designed as a peaking plant; that is, during the peak-demand hours of the day, electricity is generated by waters falling from Mount Elbert forebay through the generator into Twin Lakes afterbay. During the off-peak hours of the day, the turbines are used to pump water back up the penstocks from Twin Lakes to the Mount Elbert forebay, permitting reuse during the following days' peak-demand period. Flow-through water delivered via the Mount Elbert conduit decreases the pumpback required, thus decreasing pumping cost. Storage in Twin Lakes Reservoir for the Fryingpan-Arkansas Project will be at a maximum during 1 or 2 months in the summer, and at a minimum for the remainder of the year. Exceptions to that usage occur during years of greater-than-average runoff, when carry-over storage in the system is unusually large. Twin Lakes Reservoir stores some of the system carry-over during those periods.

From Twin Lakes Reservoir, water is released into Lake Creek, then into the Arkansas River. Twin Lakes Dam has an outlet works, that eventually will be connected to a conduit, leading to a point on the terrace, across the river and above the intake to the Homestake pipeline. This conduit, when it is connected by siphon to the Homestake pipeline, will save approximately 350 feet of hydraulic head, thus decreasing pumping cost at the Otero pumping station, when Homestake, Twin Lakes, and other waters are delivered via this route.

Fryingpan-Arkansas Project water flows from Twin Lakes to Pueblo Reservoir in the channel of the Arkansas River. The volume of water stored in Pueblo Reservoir credited to the Fryingpan-Arkansas Project is less than the volume released from Twin Lakes by the quantity of the transit loss, which currently (1983) is 0.07 percent for each mile of river channel (as decreed by the Water Court), or 9.6 percent for the 137-mile reach. 
Pueblo Reservoir is a multipurpose facility, which can be described by its space allocation. The initial reservoir-capacity allocation (before deposition of any of the 103,000 acre-feet of sediment expected to be deposited in the reservoir during the expected 100-year economic life) includes a 3,400acre-foot dead pool and a 26,600-acre-foot inactive pool (together, these comprise the recreation pool); a 234,000-acre-foot active conservation pool (to regulate imported and native waters for municipal, industrial, and irrigation uses); and a 66,000-acre-foot joint-use pool. From April 15 through November 1 each year, this joint-use space must be vacated and used for flood control. The top 27,000 acre-feet of space is for inviolate flood control. There is space for about 20 feet of surcharge above the elevation of the spillway crest $(4,898.7$ feet) that would temporarily hold 131,500 acre-feet of flood flows.

Besides river outlets through Pueblo Dam, other outlets presently deliver water to the Fountain Valley pipeline, to Pueblo West, and to Bessemer Ditch, an irrigation canal. The Fountain Valley pipeline is a 45-mile long pipeline that delivers water from Pueblo Reservoir to the city of Colorado Springs, and the communities of Stratmoor Hills, Widefield, Security, and Fountain. Outlet works have been constructed for future developments downstream from the dam, such as a municipal outlet for a future city of Pueblo water-treatment plant, and another outlet for a proposed fish hatchery.

Pueblo Reservoir has a storage right, with an appropriation date of 1939, that would enable the Fryingpan-Arkansas Project to store and retain native water during periods of major flooding. John Martin Reservoir, located about 140 miles downstream, must be full, and all diversion rights between Pueblo and John Martin Reservoirs satisfied, before the Pueblo right would come into priority.

The Southeastern Colorado Water Conservancy District was created in 1958 by State of Colorado statutes for the purpose of developing and administering the Fryingpan-Arkansas Project. The District is the legal agency responsible for repayment of the reimbursable part of the project, not including sale of power. Project-imported water and any native water stored under the 1939 Pueblo Reservoir right is sold by the District, with the receipts used for reimbursement of project costs. The District extends along the Arkansas River from Buena Vista to Lamar, and along Fountain Creek from Colorado Springs to Pueblo. The District consists of the parts of nine counties deriving benefits from the Fryingpan-Arkansas Project. About 280,600 acres of irrigated land receive supplemental irrigation water from the Fryingpan-Arkansas Project through the District (U.S. Bureau of Reclamation, 1969).

A program planned as a part of the Fryingpan-Arkansas Project, and presently being conducted under the leadership of the Southeastern Colorado Water Conservancy District and the State Water Division 2 Engineer, is the Pueblo Winter Water Storage Program. This program permits irrigators downstream from Pueblo Dam and upstream from John Martin Reservoir to store water in Pueblo Reservoir during winter months, and to use this water during the crop-growing season. The program includes off-stream storage downstream from Pueblo, and, in past years, some storage in John Martin Reservoir. The length of time and the terms of distribution of the stored water mutually are agreed to annually by a committee of representatives of water users in the valley. A copy of a recent Winter Water Agreement is found in the Supplemental Data section at the end of this report. 


\section{Arkansas River Compact}

John Martin Dam, located on the Arkansas River about 58 miles west of the Colorado-Kansas State line, was constructed by the U.S. Army Corps of Engineers as a multipurpose project. It was originally designed for flood control and irrigation-water conservation; a third use, a recreation pool, recently has been added. The reservoir was completed March 1943; but storage of water actually began in December of 1942 (U.S. Army Corps of Engineers, 1960). Storage of irrigation water in John Martin Reservoir is by agreement between the States of Colorado and Kansas. Prior to 1948, discharge from the reservoir was very irregular. In that year, a temporary agreement between the two States was reached, and a final agreement, The Arkansas River Compact, was signed by the States in December 1948, and ratified by the U.S. Congress.

Terms of the Arkansas River Compact can be found in Colorado Water Laws--a compilation of statutes, regulations, compacts, and selected cases (Radosevich and others, 1975). Generally, these terms provided for a winterand a summer-storage period. The winter-storage period, between November 1 and March 31, required all inflow to be stored, with the exception that as much as 100 cubic feet per second could be called through by Colorado water users. During the remainder of the year, river flow was stored; Colorado may demand release of as much as 500 cubic feet per second of water entering the reservoir, and Kansas may demand releases equivalent to that part of inflow between 500 and 750 cubic feet per second. Provisions were made for the rate of release of stored water, stipulating at what rate each State's water should be delivered, without reference to the volume of stored water assigned to each State. The result was that, to assure receipt of each State's share of stored water, release demands had to be made concurrently. This resulted in the drawing down of the conservation pool before all parties were ready for delivery of their water. As long as stored water remained in the reservoir, senior Colorado water rights in District 67 (downstream from John Martin Reservoir) could not call out junior rights upstream from John Martin Reservoir. When the pool was empty, the priority system applied from the Kansas State line to the headwaters.

In practice, the mode of operation dictated by the terms of the Compact agreement resulted in the reservoir gates being closed from November 1 to March 31, with most, if not all, of the inflow stored. At the end of the winter-storage season, except in rare years such as those following the 1965 flood (1965-67), the reservoir storage was drawn down to empty very early in the irrigation season, often by the middle of April.

Because of the unsatisfactory nature of this operation, a resolution was reached by members of the Arkansas River Compact Administration in 1980 (see Supplemental Data section). Under this new agreement, the stored water not immediately called by the downstream users is theoretically called from what is termed the Compact pool (or conservation pool), to what is termed the Agreement pool. This transfer takes place at a rate of 1,000 cubic feet per second when the pool contains less than 20,000 acre-feet and 1,250 cubic feet per second when the pool contains more than 20,000 acre-feet. In the Agreement pool, the water is prorated at the rate of the Compact agreement between the States of Colorado and Kansas. Colorado's share is further prorated on a basis of water rights in effect between the ditches in Water District 67 
diverting water from the Arkansas River. When the theoretical release of the stored water has decreased storage in the Compact pool to zero, the reservoir is considered dry, and rights in Water District 67 are operated in priority with the river upstream from John Martin Reservoir.

Two other recent changes have been made in the operation of John Martin Reservoir. A 10,000-acre-foot permanent pool has been stored for recreation purposes, and certain canals are storing water other than Compact water in the system. Amity Canal is storing water in John Martin Reservoir that was previously stored in the Great Plains Reservoir system. Provisions have been made to store Fort Lyon Canal and Las Animas Consolidated Canal Company water in John Martin Reservoir. The water considered for storing by these three entities is the water stored under the approved Pueblo Reservoir winter waterstorage plan. Thirty-five percent of water stored under such conditions is immediately transferred to Compact uses. All water stored is subject to a prorata share of the daily evaporation charge.

Operation under the most recent resolution is still (1983) in the exploratory stages. In response to concerns expressed by upstream water users that the theoretical transfer of water from the Compact pool to the Agreement pool went faster than under actual circumstances, a limit was placed on each District 67 ditch-storage account, above which that ditch was not allowed to call water through John Martin Reservoir. Results seem to be a more efficient use of John Martin Reservoir during the summer and in the winter storage season.

\section{Trinidad Dam and Reservoir Project}

The Trinidad Dam and Reservoir Project is a multipurpose storage project constructed by the U.S. Army Corps of Engineers on the Purgatoire River, 3 miles upstream from the city of Trinidad. Authorized in July 1958, the dam was completed in 1977.

Trinidad Dam and Reservoir provides flood protection for the city of Trinidad and for agricultura1 lands downstream. Regulation is provided for irrigation of 19,717 acres; prior to this project, these acres were irrigated with an erratic and ill-timed water supply. The permanent pool provides additional benefits of fish and wildlife management and recreation. Reservoir space allocation, as stated in the authorizing document (Public Law 85-500 85 th Congress S.3910 July 3, 1958), is flood control, 51,000 acre-feet; irrigation, 20,000 acre-feet; joint-use, 39,000 acre-feet; and fish and recreation, 4,500 acre-feet. The joint-use pool is designed for sediment accumulation, but also will be used for irrigation-water storage, until such time as the pool is filled with sediment.

Although flood control is a nonreimbursable cost, paid for from public funds appropriated in the authorization act, the cost of the Trinidad Dam and Reservoir Project allocated to irrigation is reimbursable; that is, irrigation is expected to be self-supporting through a charge for the regulation of the water. The Purgatoire River Water Conservancy District is the entity established under the laws of the State of Colorado, whose responsibility it is to regulate the irrigation supply in the Trinidad Dam and Reservoir Project, to 
repay the reimbursable cost, and to pay irrigation's share of the operation and maintenance cost. To facilitate this repayment, a contract between the United States (acting through the U.S. Bureau of Reclamation) and the Purgatoire River Water Conservancy District is in effect. This Conservancy District operates under the Operating Principles, Trinidad Dam and Reservoir Project, and the Purgatoire River Water Conservancy District Operating Criteria. Copies of both of these documents are reproduced in a report by the U.S. Bureau of Reclamation, (1964).

A summary of the irrigation operations of the Conservancy District follows. Water rights for the 20,000-acre-foot irrigation pool were provided by the transfer of the Model Reservoir 1908 storage decree to Trinidad Reservoir. The project has a 1950 storage decree for the joint-use pool. Trinidad Reservoir stores and regulates flows surplus to downstream requirements plus flows accruing to the Model Reservoir storage rights. Use of the project water is limited to 19,717 acres of irrigatable land, served by 11 ditch systems (fig. 20). The objective of the Conservancy District's water administration is to improve the effectiveness of water use by limiting the service area to 19,717 acres of irrigatable land, and by restricting water deliveries to seasonal-crop requirements. To this purpose, the Conservancy District has control of the water rights of the 11 ditches at any time water is in the irrigation pool. When the pool is empty, operation of the ditch's rights reverts to the priority system. In conducting the regulation, the operation principles require that flow of the Purgatoire River downstream from the project area not be decreased to less than that had the Model right not been transferred. The city of Trinidad is entitled to some of the water stored under the project's decrees, but to date, the city's shares have not been put to municipal use.

Twin Lakes Project

The Twin Lakes Project transmountain diversion system was constructed in the $1930^{\prime} \mathrm{s}$ to serve land irrigated by the Colorado Canal in Crowley County. The collection system (fig. 23) is located in eastern Pitkin County at the headwaters of the Roaring Fork River. Waters of the Roaring Fork River and Lost Man Creek are diverted through Twin Lakes Reservoir Tunnel 2 into Lincoln Gulch, and, eventually, into Grizzly Reservoir. The New York Collection Canal conveys water diverted from New York Creek and Tabor Creek, south-bank tributaries of Lincoln Gulch to Grizzly Reservoir. From here, the water is transported through the Continental Divide into North Fork Lake Creek in the Twin Lakes (Independence Pass) Tunnel. The imported water is stored for later release in the 54,453 acre-feet of storage space in Twin Lakes Reservoir owned by the Twin Lakes Reservoir and Canal Company. This company also retains storage decrees for native water in Twin Lakes Reservoir. Diversions through the Twin Lakes Tunnel began on May 24, 1935. An average of 54,500 acre-feet is considered an annual supply to the Twin Lakes Project.

The site of Twin Lakes Reservoir was purchased from the Twin Lakes Reservoir and Canal Company by the U.S. Bureau of Reclamation. The reservoir has been enlarged to 140,339 acre-feet and is used by the Fryingpan-Arkansas Project for storage and as an afterbay for that project's Mount Elbert powerplant. 


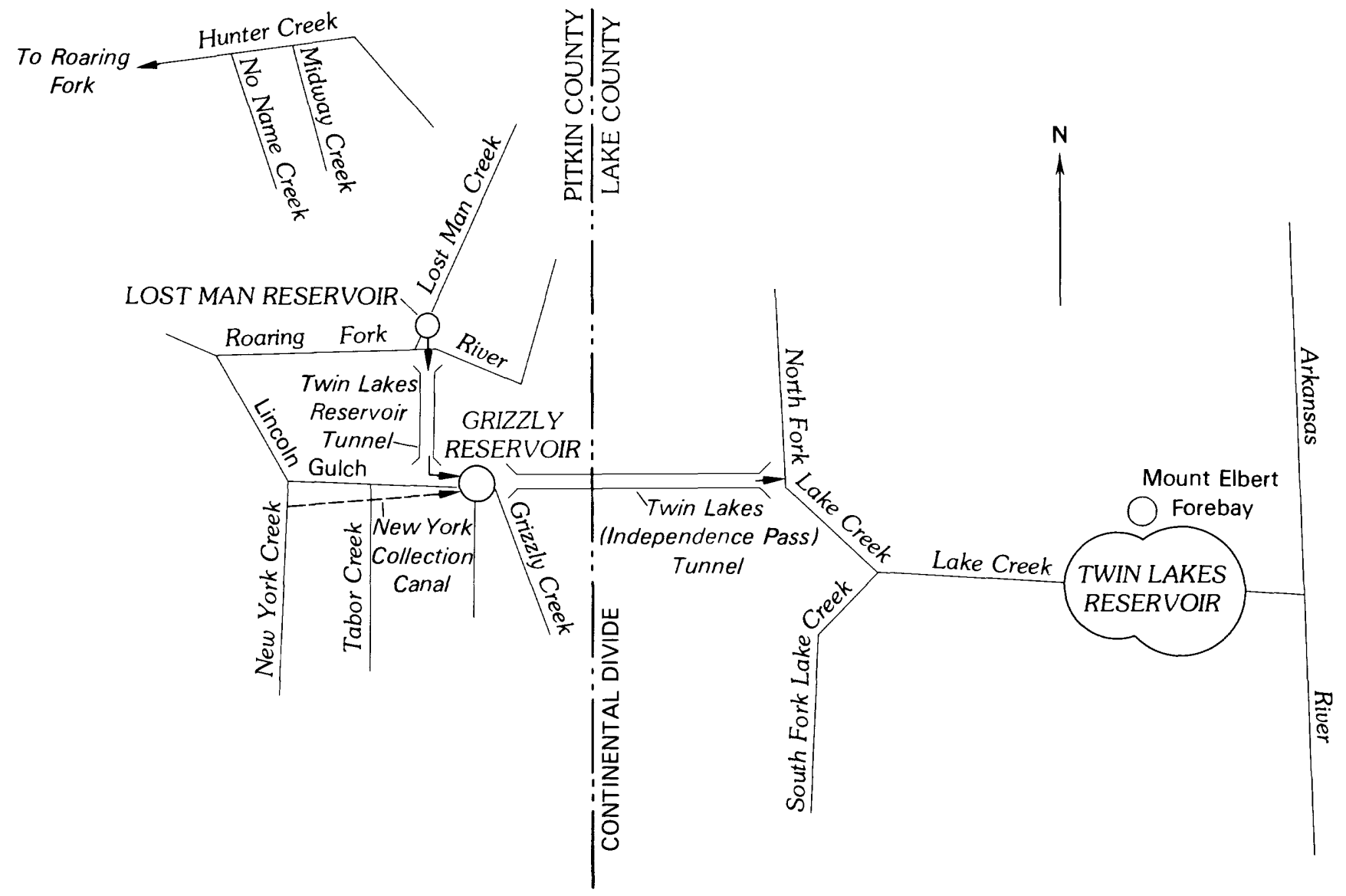

Figure 23.--Twin Lakes Project system.

As a part of the transaction, the Twin Lakes Company retained the use of 54,453 acre-feet of storage capacity in the reservoir and gained an option to lease an additional 20,000 acre-feet of storage space in the FryingpanArkansas system.

An additional involvement between the Fryingpan-Arkansas Project and the Twin Lakes Project is a 3,000-acre-foot exchange. Under this arrangement, the Twin Lakes Project foregoes or bypasses 3,000 acre-feet of flow, at an agreed rate past its diversion system, to supply flow for fish and recreation downstream in the Roaring Fork River. In return, the Fryingpan-Arkansas Project diverts an additional 3,000 acre-feet annually from Hunter Creek, and delivers it to the Twin Lakes water users in the Arkansas River basin. The net result is that flow in the Roaring Fork downstream from the Twin Lakes system is enhanced, and an additional 3,000 acre-feet of water is available to the generators of the Mount Elbert powerplant (described with the Fryingpan-Arkansas Project elsewhere in this report). 
In recent years, ownership of the Twin Lakes transmountain and storage system has been transferred from the irrigators of lands served by the Colorado Canal to entities whose water use is elsewhere. The 49,588.965 outstanding shares of Twin Lakes ownership are presently (1983) distributed as follows: 2,754.41 to Colorado Canal Irrigators; 2,434.655 to Aurora; 27,099.70 to Colorado Springs; $11,476.20$ to Pueblo; 5,732.40 to Pueblo West; 91.6 to Olney Springs; 32.0 to Colorado Water Division 2 under various plans for augmentation (Jack McCullough, Twin Lakes Reservoir and Canal Company, oral commun., 1983). Aurora and Colorado Springs presently are using their shares as municipal water. Pueblo West has used some municipal water from its shares. Pueblo has not put its shares to municipal use but decides, on a year-to-year basis, whether its shares should be used in its own system, or made available to the irrigators obtaining water from the Colorado Canal. olney Springs uses its shares in a plan for augmentation; its water, along with water from other plans for augmentation, is released to the river.

\section{USE OF THE REPORT}

The foregoing discussion describes the operation of the various Arkansas River basin water-supply systems during the past several decades. Anyone studying the flow of that river as represented in streamflow records collected during the period will need an understanding of these operations to interpret the streamflow records. In recent years there has been an acceleration in the change of the described operations. As the demand for water becomes greater due to expanding population, the patterns of water use have changed. Recent changes in CF\&I Steel Corporation's water needs were described in the section on industrial users. The economic climate of agriculture is causing irrigators in the basin to consider selling their water rights to municipalities, both in and out of the basin. The need to study the effects of these patterns of water use is the basis upon which the Arkansas River model was developed.

\section{REFERENCES}

Adkins, R.W., 1962, Water supply for an integrated steel plant at high altitude: San Francisco, Regional Technical Meeting of American Iron and Steel Institute, Preprint, $10 \mathrm{p}$.

Arkansas River Compact Administration, 1980, Thirty-second annual report: Lamar, Colorado, $50 \mathrm{p}$.

Berry, J.W., 1959, Climates of the states, Colorado, Climatography of the United States No. 60-5: U.S. Weather Bureau, $16 \mathrm{p}$.

Fenneman, N.M., 1931, Physiography of the western United States: New York, McGraw-Hi11, $534 \mathrm{p}$.

Luckey, R.R., and Livingston, R.K., 1975, Reservoir release routing model for the Upper Arkansas River basin in Colorado: Denver, Colorado Water Conservation Board Water-Resources Circular 27, 44 p.

Major, T.J., Hurr, R.T., and Moore, J.E., 1970, Hydrogeologic data for the lower Arkansas River valley, Colorado: Denver, Colorado Water Conservation Board Basic-Data Release 21, $125 \mathrm{p}$.

McCullough, J.A., and Miskel, H.E., 1974, Water Resources and historical water use for Colorado Springs, Colorado: Colorado Springs, Resources Planning and Development Board, $60 \mathrm{p}$. 
McHendrie, A.W., 1928, The Hatcher Ditch: Denver, Colorado State Historical Society, Colorado Magazine, v. 5, no. 3, p. 81-95.

Radosevich, G.E., Hamburg, D.H., and Swick, L.L., 1975, Colorado water laws--A compilation of statutes, regulations, compacts, and selected cases: Fort Collins, Colorado State University, 3 vols.

Taylor, R.C., 1963, Colorado south of the border: Denver, Sage Press, 457 p.

U.S. Army Corps of Engineers, 1960, Report on sedimentation, John Martin Reservoir, Arkansas River basin, Colorado, Resurvey of August 1957: Albuquerque, $33 \mathrm{p}$.

U.S. Bureau of the Census, 1980, 1981, Census of population and housing, Colorado, primary population and housing counts: Washington, D.C., 8 p.

U.S. Bureau of Reclamation, 1964, Irrigation report on the Trinidad Project, Colorado, v. 1: Denver, 57 p. 1969, Report on the Upper Arkansas River basin, Colorado, Kansas: Pueb1o, Fryingpan-Arkansas Project Office, $146 \mathrm{p}$.

U.S. Geological Survey, 1970, The national atlas of the United States of America: Washington, D.C., 417 p.

U.S. Weather Bureau, 1959, Climate of the States--Colorado: Washington, D.C., $16 \mathrm{p}$. 
SUPPLEMENTAL DATA 


\section{OPERATING PLAN \\ ( Pueblo Reservoir ) \\ WINTER WATER YEAR 1982 - 1983}

Furnished by Charles L. (Tommy) Thompson, Chairman of Winter Water Storage Program Board of Trustees

The Winter Water Storage Program shall be operated under the direction of the Board of Trustees, composed of one member of each affected ditch which elects to be represented by a member of the Board. Each member elected by and from the Board shall meet at frequent intervals to make all recommendations necessary for the equitable distribution of direct flow water in the Program, which recommendations shall be based on the following general guidelines:

1. River flows in excess of the amount of the flow necessary to supply priorities not participating may be stored in Pueblo Reservoir and other off-channel storage facilities of participating entities during the period from November 15, 1982, to March 15, 1983.

2. Ditches shall have the option as to whether or not they store in Pueblo Reservoir or operate as they have in the past. Such participation shall guarantee that operation under this plan will not (a) injure their water rights, (b) commit them to any future plan or plans, (c) give up any other rights they may develop in the future, (d) create any record that will be used in any legal action, and (e) a record will be kept of all ditches electing to divert, and made a part of the Winter Water Program.

3. The river call during the period of storage will be the priority date of the most junior water right which is either receiving water, or receiving credit in Pueblo Reservoir.

4. The Division Engineer shall keep a record of all water stored or diverted and shall apportion to all participating entities on the basis of the attached tables, or any other basis approved by the Board.

5. All entities agree that the transportation loss for Winter Water shall be based on the USGS study and all entities storing in Pueblo will pay their own loss from Pueblo Reservoir.

6. A charge, including evaporation, will be made for Winter Water stored in Pueblo Reservoir during the Program's operation for the 1982-1983 Winter Storage period.

7. It is further understood and agreed that all companies entering into this agreement do not waive any of their rights or interests to water rights and priorities thereto, except as to the temporary suspension of said rights as provided in the Program, and that the agreement from each Company is subject to confirmation and approval by the stockholders of each Company at its next regular annual meeting, and if not so approved, the agreement to participate in the Program will be void and of no effect. Such withdrawal from the Experimental Storage Program, and said Company will continue to divert its water under its decree, and will withdraw waters which had been accumulated to its account between the time the Program began, and the date when the shareholders elected not to participate.

8. During the time of low flow, it may be necessary for the Division Engineer to advise that he may not be able to identify the reservoir run and little or no credit may be given for the release. 

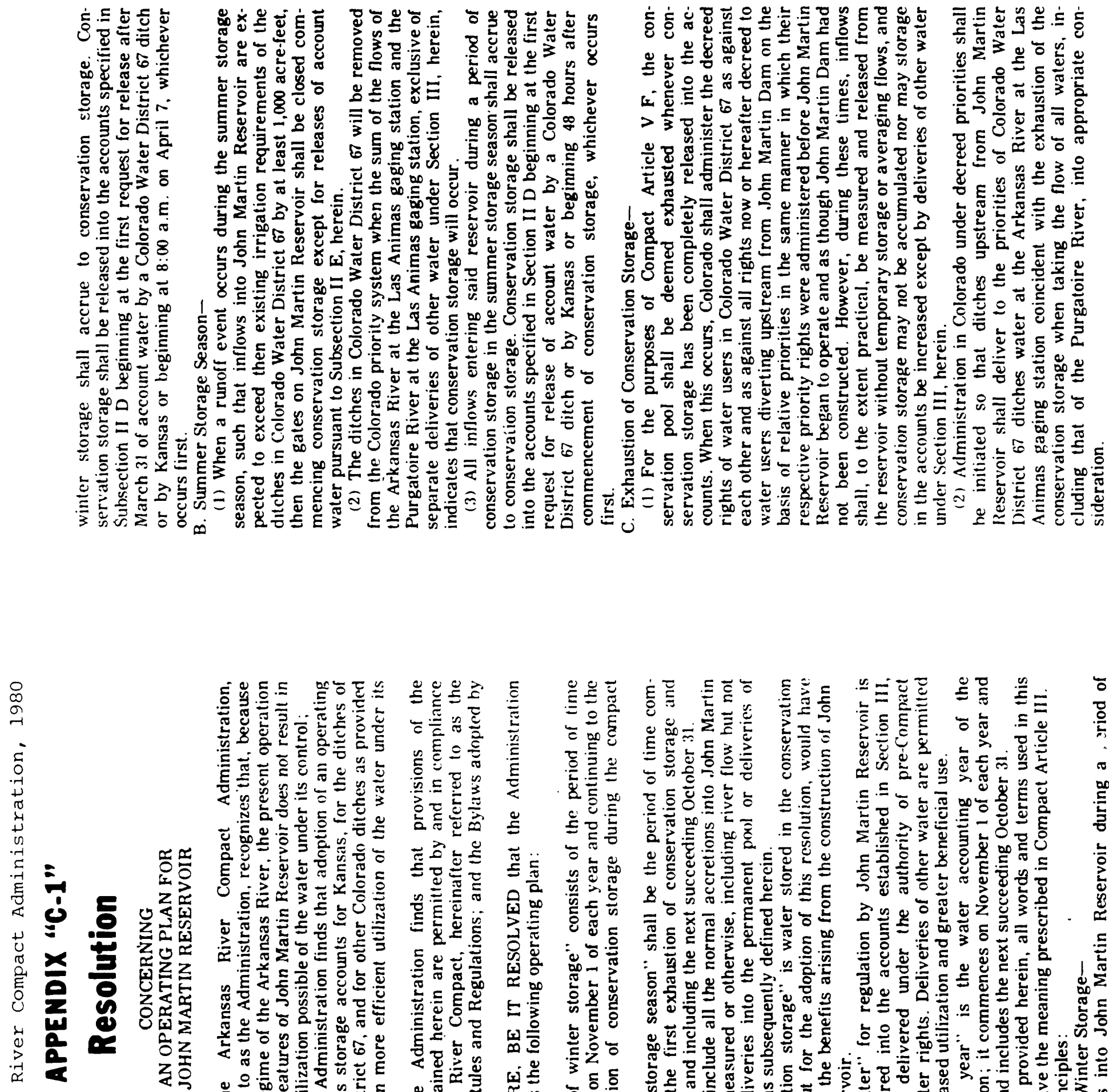

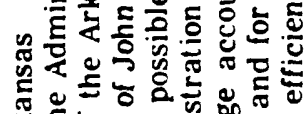

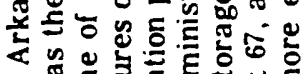

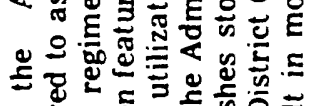

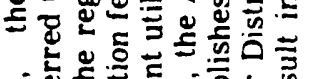

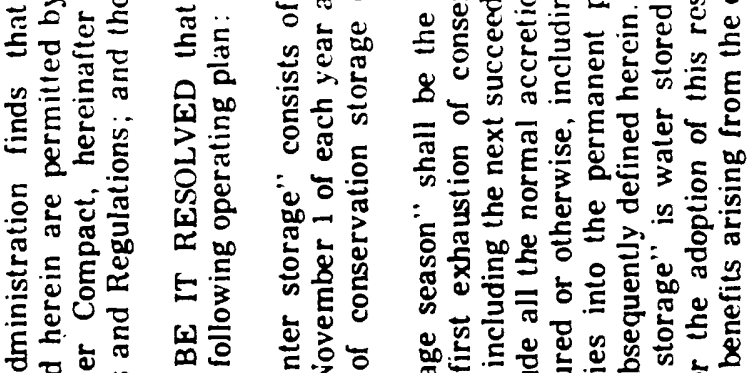

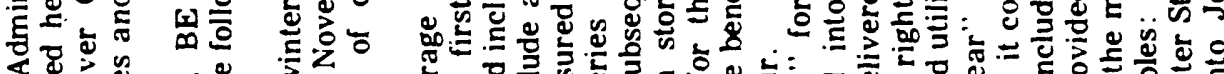

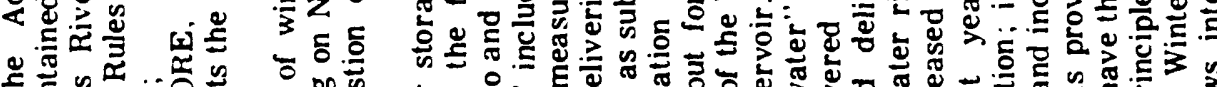

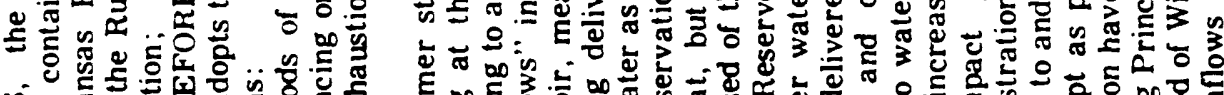

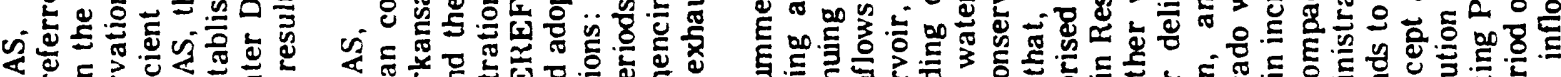

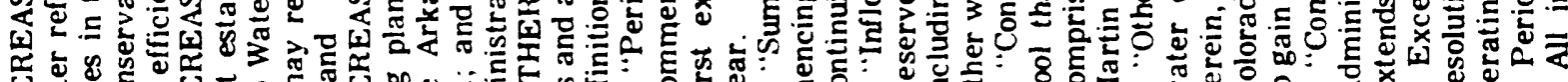

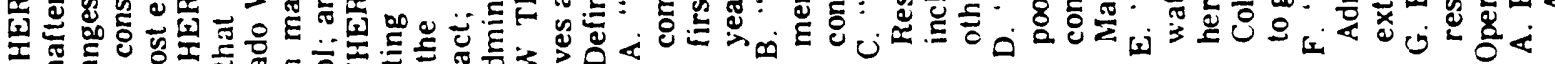

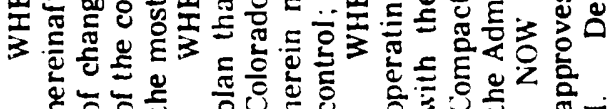




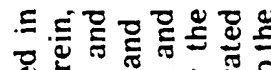

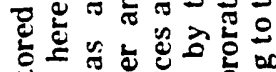

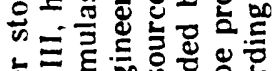

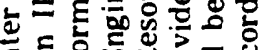

元

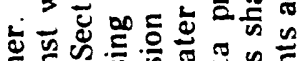

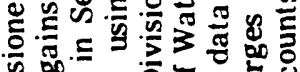

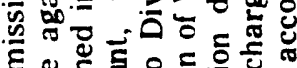

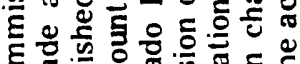

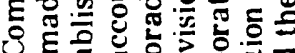

O)

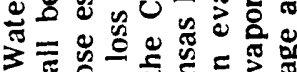

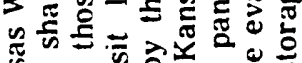

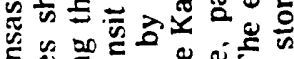

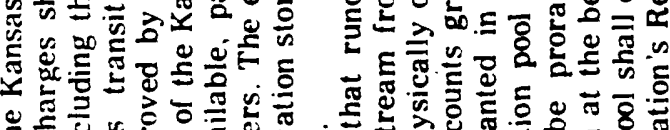

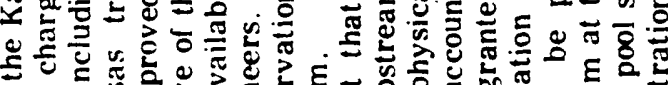

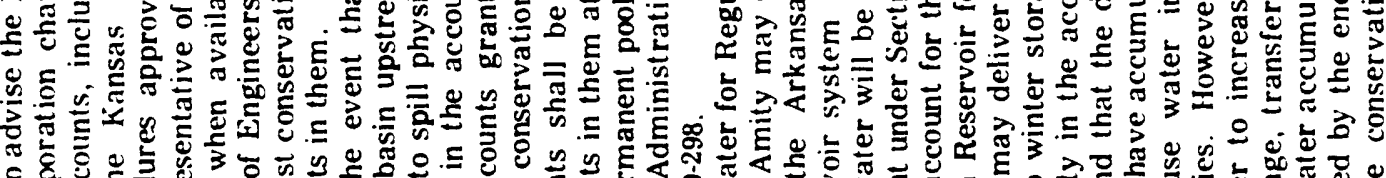

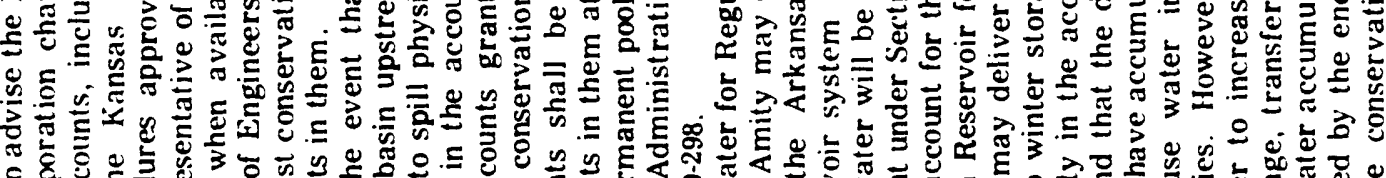

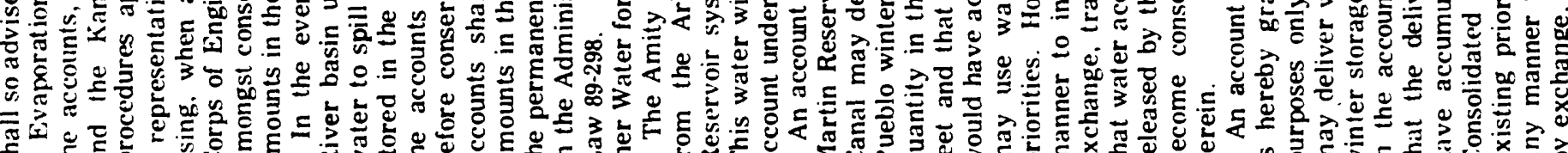

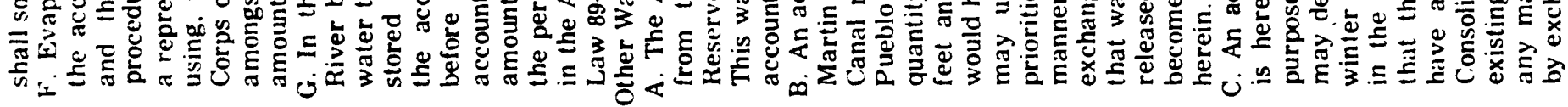

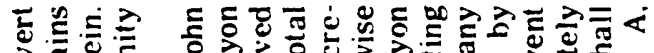

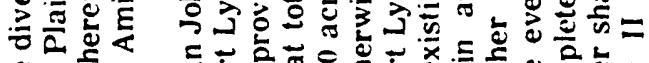
능

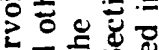

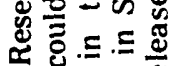

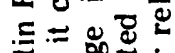

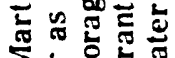
2 的的事

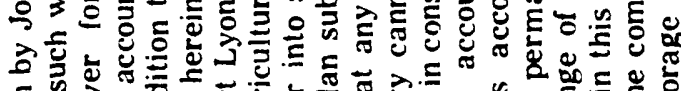

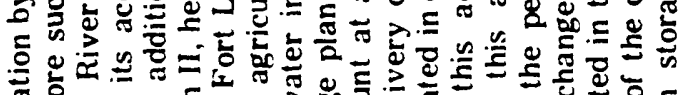
西 क人

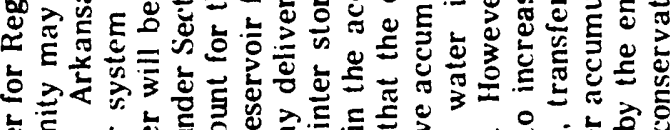

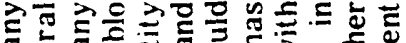

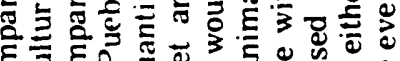
है

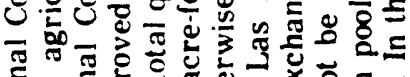
厄゙

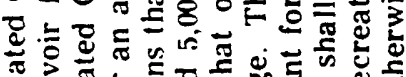

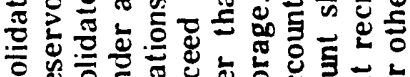

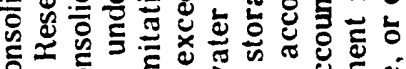

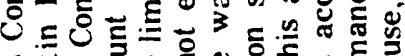

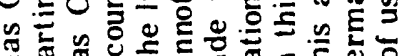
ह

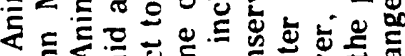

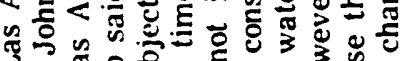

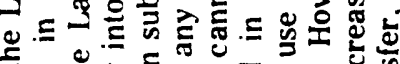

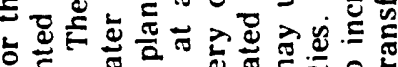
政

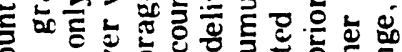
政 느는

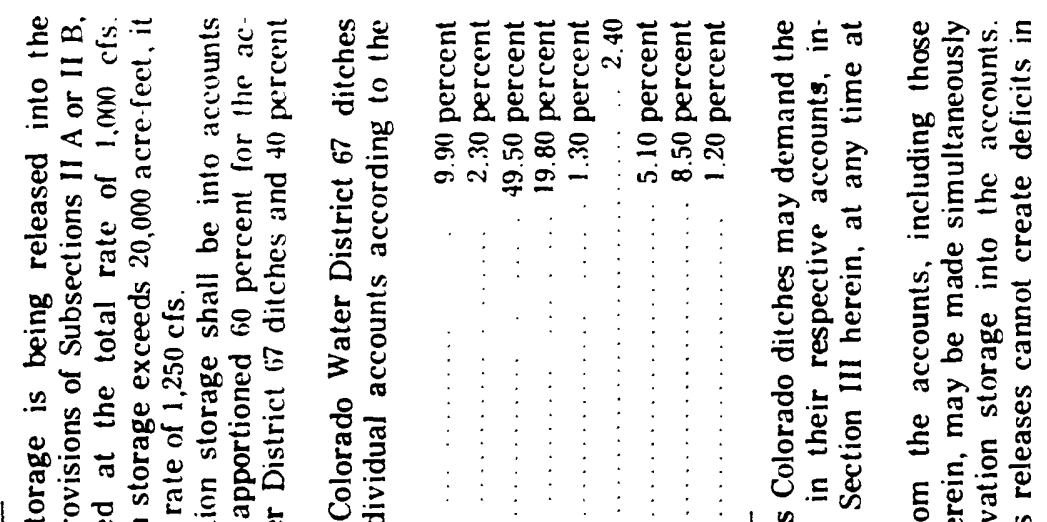

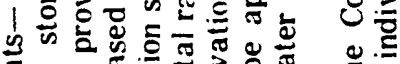

引

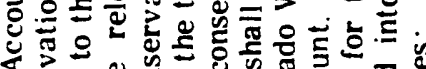

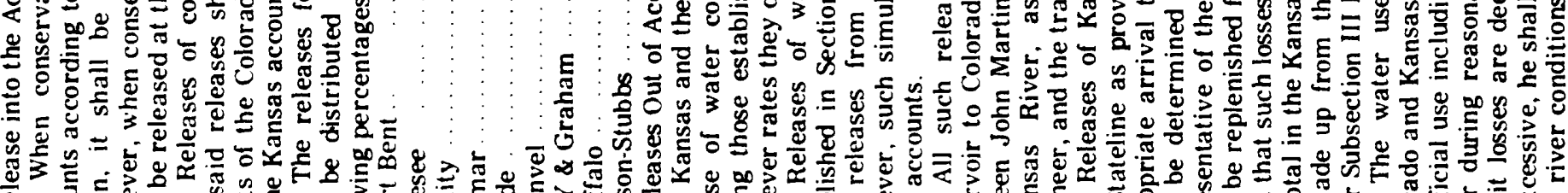

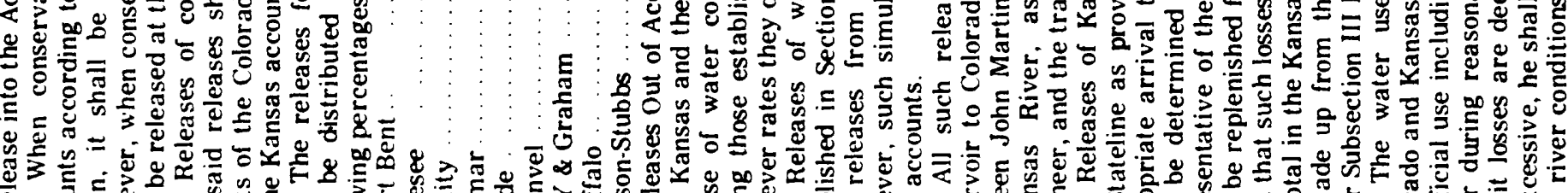

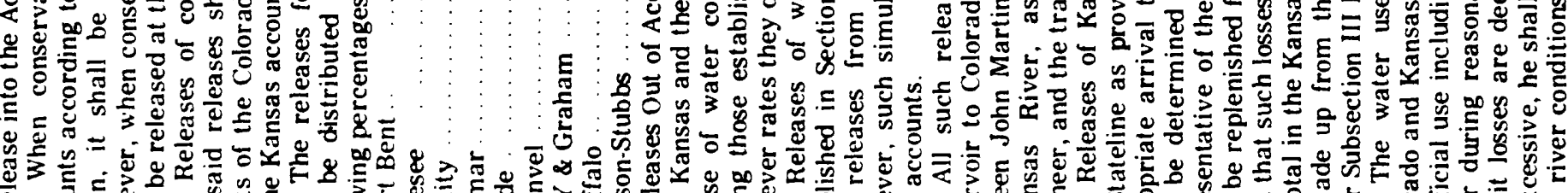

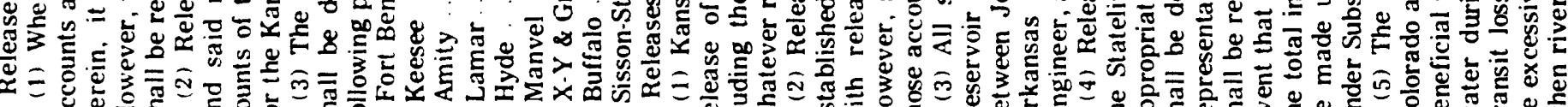

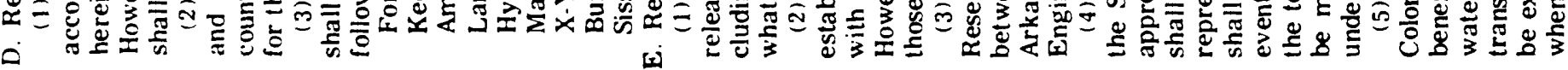




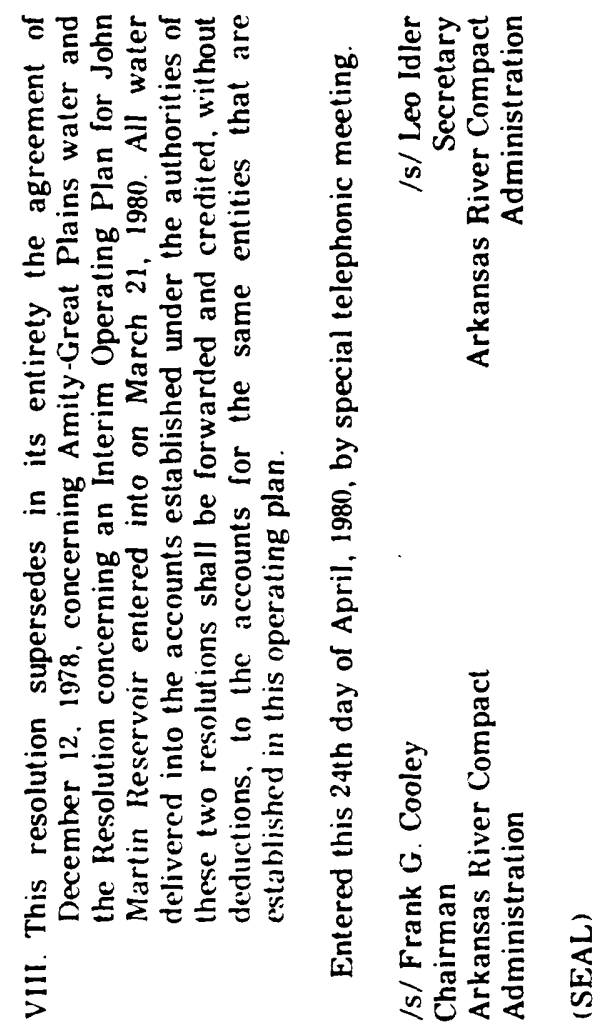

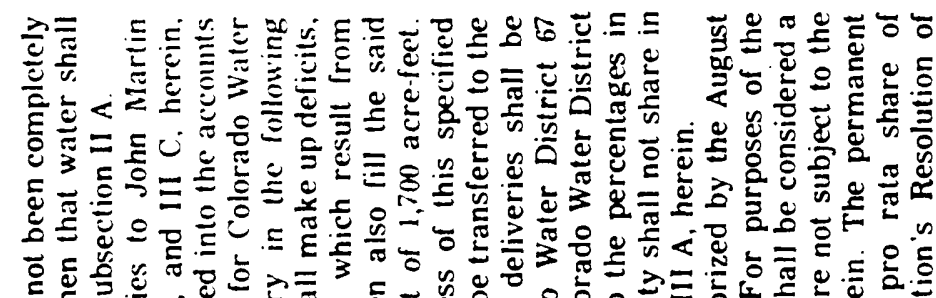

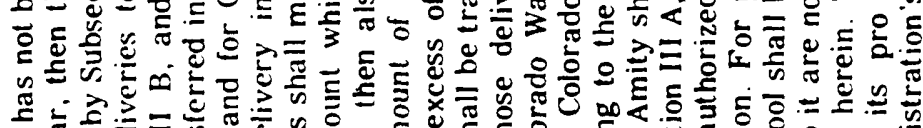

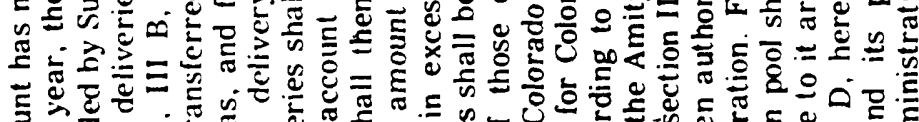

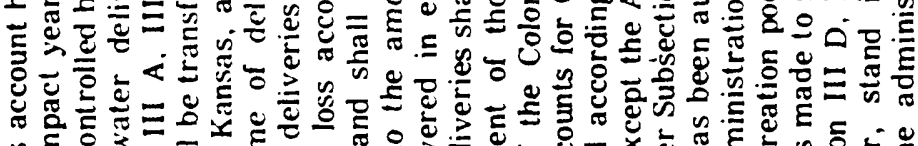

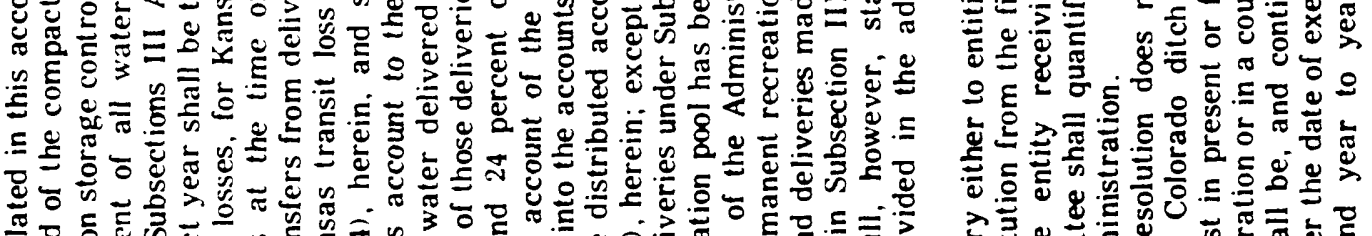

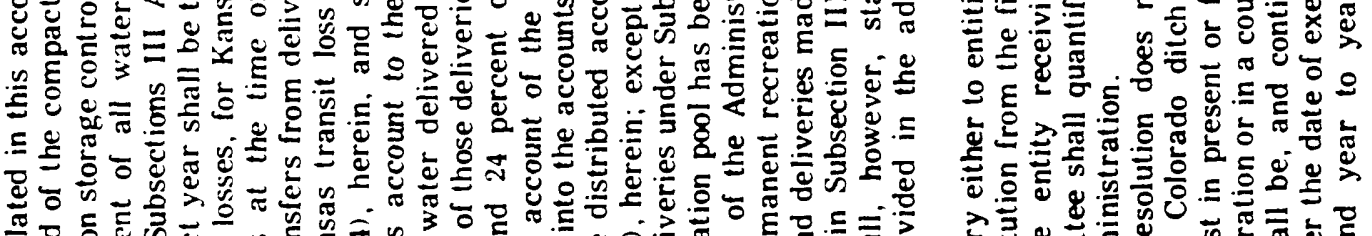

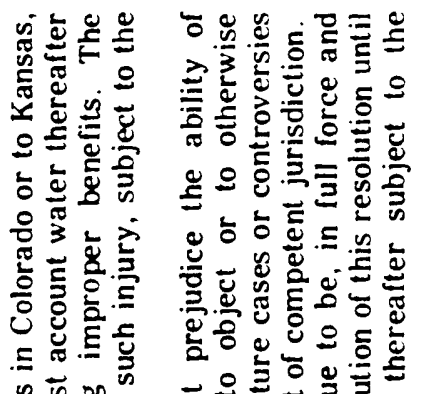
\& won

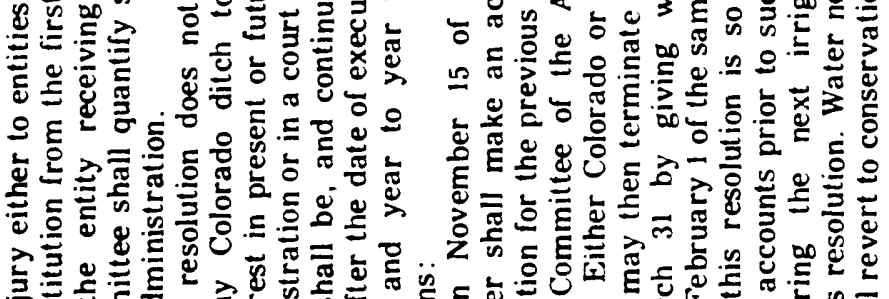

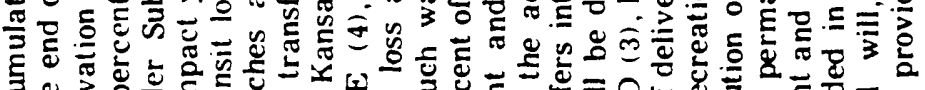

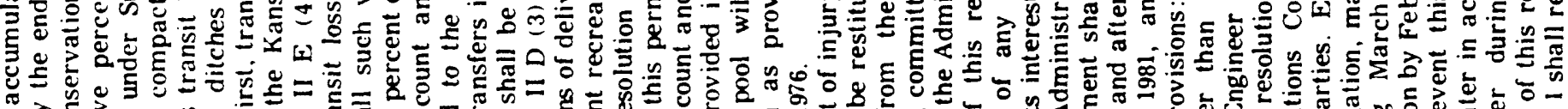

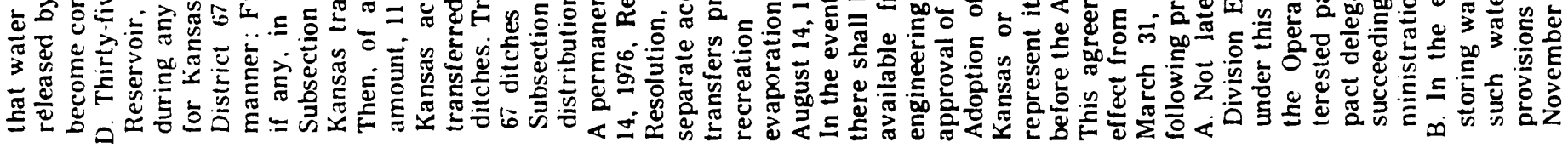

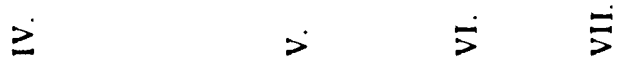


Table 2.--Conduits in the area

\begin{tabular}{|c|c|c|c|c|c|c|c|c|c|c|}
\hline \multirow[b]{2}{*}{ Name } & \multirow{2}{*}{$\begin{array}{c}\text { Map } \\
\text { number } \\
\text { on } \\
\text { plate } 1\end{array}$} & \multicolumn{4}{|c|}{ Location } & \multirow[b]{2}{*}{$\begin{array}{l}\text { Length } \\
\text { (miles) }\end{array}$} & \multirow[b]{2}{*}{$\begin{array}{l}\text { Diameter } \\
\text { (inches) }\end{array}$} & \multirow[b]{2}{*}{ Use } & \multirow{2}{*}{\multicolumn{2}{|c|}{ Operator }} \\
\hline & & $\begin{array}{l}\text { Sec- } \\
\text { tion }\end{array}$ & $\begin{array}{l}\text { Town- } \\
\text { ship }\end{array}$ & Range & $\begin{array}{c}\text { Prime } \\
\text { meridian }\end{array}$ & & & & & \\
\hline Cunningham conduit ${ }^{1}-\ldots$ & 1 & 27 & $8 s$ & $82 w$ & 6 & 0.8 & 60 & Multiple purpose & Fryingpan-Arkansas & Project \\
\hline Fountain Valley & 2 & 15 & $15 s$ & $66 w$ & 6 & 38.2 (trunk) & $33,39,42$ & Municipal & Fryingpan-Arkansas & Project \\
\hline pipeline. & & 7 & $15 s$ & $65 w$ & 6 & $7.6($ lateral $)$ & 14,24 & & & \\
\hline Fryingpan conduit ${ }^{1}$ & 3 & 23 & $9 \mathrm{~s}$ & $82 w$ & 6 & 0.5 & 84 & Multiple purpose & Fryingpan-Arkansas & Project \\
\hline Granite siphon 1 & 4 & 16 & $9 \mathbf{s}$ & $82 w$ & 6 & 0.7 & 30,36 & Multiple purpose & Fryingpan-Arkansas & Project \\
\hline Homestake pipeline---- & 5 & 28 & $12 \mathrm{~s}$ & $68 w$ & 6 & $\begin{array}{l}50 \\
26\end{array}$ & $\begin{array}{l}66 \\
48\end{array}$ & Municipal & Homestake Project & \\
\hline Montgomery pipeline--- & 6 & 14 & $13 \mathrm{~s}$ & $69 w$ & 6 & 70 & 30 & Municipal & Blue River Project & \\
\hline Monument Lake pipeline- & 7 & 32 & $32 s$ & $68 w$ & 6 & 2.2 & -- & Municipal & City of Trinidad & \\
\hline Mormon conduit 1 & 8 & 15 & $8 s$ & $82 w$ & 6 & 0.3 & 45 & Multiple purpose & Fryingpan-Arkansas & Project \\
\hline Mount Elbert conduit--- & 9 & 8 & $11 \mathrm{~s}$ & $80 w$ & 6 & 10.7 & 90 & Multiple purpose & Fryingpan-Arkansas & Project \\
\hline North Lake pipeline---- & 10 & 32 & $32 s$ & $68 w$ & 6 & 2.5 & -- & Municipal & City of Trinidad & \\
\hline Sawyer conduit ${ }^{1}$ & 11 & 23 & $9 s$ & $83 w$ & & 0.6 & 27 & Multiple purpose & Fryingpan-Arkansas & Project \\
\hline $\begin{array}{l}\text { South Cunningham } \\
\text { conduit }{ }^{1} \text {. }\end{array}$ & 12 & 27 & $8 s$ & $82 w$ & 6 & 0.7 & $18,21,24$ & Multiple purpose & Fryingpan-Arkansas & Project \\
\hline WaIsenburg pipeline---- & 13 & 28 & $29 s$ & $68 w$ & 6 & 1.7 & 16 & Municipal & City of Walsenburg & \\
\hline
\end{tabular}

${ }^{1}$ Conduit located outside the Arkansas basin. 
Table 3.--Tunnels in the area

\begin{tabular}{|c|c|c|c|c|c|c|c|c|c|c|}
\hline \multirow{2}{*}{ Name } & \multirow{2}{*}{$\begin{array}{c}\text { Map } \\
\text { number } \\
\text { on } \\
\text { plate } 1\end{array}$} & \multicolumn{4}{|c|}{ Location of outlet } & \multicolumn{2}{|c|}{ Drainage } & \multirow{2}{*}{$\begin{array}{l}\text { Capacity } \\
\text { (cubic } \\
\text { feet per } \\
\text { second) } \\
\end{array}$} & \multirow{2}{*}{ Use } & \multirow{2}{*}{ Operator } \\
\hline & & $\begin{array}{l}\text { Sec- } \\
\text { tion }\end{array}$ & $\begin{array}{r}\text { lown- } \\
\text { ship }\end{array}$ & Range & $\begin{array}{l}\text { Prime } \\
\text { meridian }\end{array}$ & From & To & & & \\
\hline $\begin{array}{l}\text { Busk-Ivanhoe } \\
\text { (Carlton) }\end{array}$ & 1 & 20 & $9 \mathrm{~s}$ & $81 w$ & 6 & Ivanhoe Creek & Busk Creek & & $\begin{array}{l}\text { Municipal and } \\
\text { agricultural. }\end{array}$ & $\begin{array}{l}\text { Pueblo and } \\
\text { Highline Canal. }\end{array}$ \\
\hline Canterbury & 2 & 12 & $9 \mathrm{~s}$ & $80 w$ & 6 & & East Fork & & Mine drainage & \\
\hline Carlton- & 3 & 10 & $16 s$ & $70 w$ & 6 & & $\begin{array}{c}\text { Four Mile } \\
\text { Creek. }\end{array}$ & & Mine drainage & \\
\hline Carlton- & 1 & -see & Busk-I & Ivanhoe & & & & & & \\
\hline Carter ${ }^{1} \ldots \ldots$ & 4 & 15 & $8 s$ & $82 w$ & 6 & Carter Creek & Mormon Creek & 100,130 & $\begin{array}{l}\text { Multiple } \\
\text { purpose. }\end{array}$ & $\begin{array}{l}\text { Fryingpan-Arkansas } \\
\text { Project. }\end{array}$ \\
\hline Chapman ${ }^{1}-\ldots$ & 5 & 30 & $9 s$ & $82 w$ & 6 & Chapman Gulch & South Fork & 300 & $\begin{array}{l}\text { Multiple } \\
\text { purpose. }\end{array}$ & $\begin{array}{l}\text { Fryingpan-Arkansas } \\
\text { Project. }\end{array}$ \\
\hline Charles H. Boustead- & 6 & 10 & $9 s$ & $81 w$ & 6 & Fryingpan River & Lake Fork & 945 & $\begin{array}{l}\text { Multiple } \\
\text { purpose. }\end{array}$ & $\begin{array}{l}\text { U.S. Bureau of } \\
\text { Reclamation. } \\
\text { Fryingpan-Arkansas } \\
\text { Project. }\end{array}$ \\
\hline Cunningham- & 7 & 4 & $9 s$ & $82 w$ & 6 & $\begin{array}{l}\text { Middle Cunning- } \\
\text { ham Creek. }\end{array}$ & $\begin{array}{l}\text { Ivanhoe } \\
\text { Creek. }\end{array}$ & 270 & $\begin{array}{l}\text { Multiple } \\
\text { purpose. } \\
\text { Municipal }\end{array}$ & $\begin{array}{l}\text { Fryingpan-Arkansas } \\
\text { Project. } \\
\text { Homestake Project }\end{array}$ \\
\hline Homestake-- & 9 & 9 & $9 s$ & $81 \mathrm{w}$ & 6 & Homestake Creek & Lake Fork & & Municipal & Homestake Project \\
\hline Hoosier- & 10 & 14 & $8 s$ & $78 w$ & 6 & Blue River & $\begin{array}{l}\text { Middle Fork } \\
\text { South Platte. }\end{array}$ & & Municipal & Blue River Project \\
\hline Hunter ${ }^{1}-\ldots \ldots$ & 11 & 23 & $9 \mathrm{~S}$ & $83 \mathrm{~W}$ & 6 & Hunter Creek & Chapman Gulch & $\begin{array}{l}90,175 \\
270\end{array}$ & $\begin{array}{l}\text { Multiple } \\
\text { purpose. }\end{array}$ & $\begin{array}{l}\text { Fryigpan-Arkansas } \\
\text { Project. }\end{array}$ \\
\hline $\begin{array}{l}\text { Independence Pass--- } \\
\text { (Twin Lakes) }\end{array}$ & 12 & 22 & $11 \mathrm{~s}$ & $82 w$ & 6 & Lincoln Gulch & $\begin{array}{c}\text { North Fork of } \\
\text { Lake Creek. }\end{array}$ & & $\begin{array}{l}\text { Municipal and } \\
\text { agricultural. }\end{array}$ & Twin Lakes Project \\
\hline Leadville drainage-- & 13 & 13 & $9 s$ & $80 w$ & 6 & & East Fork & & Mine drainage & \\
\hline Little Annie & 14 & & & & & & & & Municipal & Homestake Project \\
\hline McCullough ${ }^{1} \ldots$ & 15 & 26 & $7 \mathrm{~s}$ & $78 w$ & 6 & Spruce Creek & $\begin{array}{l}\text { McCullough } \\
\text { Creek. }\end{array}$ & & Municipal & Blue River Project \\
\hline Missouri ${ }^{1}-\ldots$ & 16 & 17 & $8 s$ & $81 \mathrm{w}$ & 6 & Missouri Creek & $\begin{array}{l}\text { Homestake } \\
\text { Creek. }\end{array}$ & 300 & Municipal & Homestake Project \\
\hline Mormon ${ }^{1}-\ldots$ & 17 & 22 & $8 s$ & $82 w$ & 6 & Mormon Creek & $\begin{array}{l}\text { North Cun- } \\
\text { ningham } \\
\text { Creek. }\end{array}$ & 190 & $\begin{array}{l}\text { Multiple } \\
\text { purpose. }\end{array}$ & $\begin{array}{l}\text { Fryingpan-Arkansas } \\
\text { Project. }\end{array}$ \\
\hline Nast-mo & 18 & 23 & $9 \mathrm{~s}$ & $82 w$ & 6 & Ivanhoe Creek & $\begin{array}{l}\text { Fryingpan } \\
\text { River. }\end{array}$ & 360 & $\begin{array}{l}\text { Multiple } \\
\text { purpose. }\end{array}$ & $\begin{array}{l}\text { Fryinpan-Arkansas } \\
\text { Project. }\end{array}$ \\
\hline Quandary ${ }^{1} \ldots \ldots$ & 19 & 2 & $8 s$ & $78 w$ & 6 & McCullough Creek & Blue River & & Municipal & Blue River Project \\
\hline Rampart Range No.1-- & 20 & 2 & $13 s$ & $68 w$ & 6 & $\begin{array}{l}\text { North Slope } \\
\text { Pikes Peak. }\end{array}$ & $\begin{array}{l}\text { West Monument } \\
\text { Creek. }\end{array}$ & & Municipal & Colorado Springs \\
\hline Rampart Range No.2-- & 21 & 28 & $12 \mathrm{~s}$ & $68 w$ & 6 & Fountain Creek & $\begin{array}{l}\text { West Monument } \\
\text { Creek. }\end{array}$ & & Municipal & Colorado Springs \\
\hline Roberts-- & 22 & 23 & $15 \mathrm{~s}$ & $68 w$ & 6 & Gould Creek & $\begin{array}{l}\text { East Beaver } \\
\text { Creek. }\end{array}$ & & Municipal & Colorado Springs \\
\hline Roosvelt-n & 23 & 3 & $16 s$ & $70 \mathrm{w}$ & 6 & & Cripple Creek & & Mine drainage & \\
\hline Saint Johns & 24 & 32 & $14 \mathrm{~s}$ & $68 w$ & 6 & $\begin{array}{l}\text { Middle Beaver } \\
\text { Creek. }\end{array}$ & Ruxton & & Municipal & Colorado Springs \\
\hline South Fork- & 25 & 23 & $9 s$ & $82 w$ & 6 & $\begin{array}{l}\text { South Fork of } \\
\text { Fryingpan } \\
\text { River. }\end{array}$ & $\begin{array}{l}\text { Fryingpan } \\
\text { River. }\end{array}$ & 450 & $\begin{array}{l}\text { Multiple } \\
\text { purpose. }\end{array}$ & $\begin{array}{l}\text { Fryingpan-Arkansas } \\
\text { Project. }\end{array}$ \\
\hline Strickler & 26 & 19 & $14 \mathrm{~s}$ & $68 \mathrm{w}$ & 6 & $\begin{array}{l}\text { East Fork of } \\
\text { West Beaver } \\
\text { Creek. }\end{array}$ & Boehmer Creek & & Municipal & Colorado Springs \\
\hline Twin Lakes--- & 12 & -see & Indepen & ndence & Pass & & & & & \\
\hline $\begin{array}{l}\text { Twin Lakes Reservoir } \\
\text { Tunnel No. } 2 \text {. }\end{array}$ & 27 & 14 & $11 \mathrm{~s}$ & $83 w$ & 6 & $\begin{array}{l}\text { Roaring Fork } \\
\text { River. }\end{array}$ & Lincoln Gulch & & $\begin{array}{l}\text { Municipal and } \\
\text { agricultural. }\end{array}$ & $\begin{array}{l}\text { Twin Lakes } \\
\text { Project. }\end{array}$ \\
\hline Yak- & 28 & 30 & $9 \mathrm{~s}$ & $79 w$ & 6 & & $\begin{array}{l}\text { California } \\
\text { Gulch. }\end{array}$ & & Mine drainage & \\
\hline
\end{tabular}

${ }^{1}$ Tunnel located outside the Arkansas River basin. 
Table 4.--Major ditches in the area

\begin{tabular}{|c|c|c|c|c|c|c|c|c|c|c|}
\hline \multirow[b]{2}{*}{ Name $^{1}$} & \multirow{2}{*}{$\begin{array}{c}\text { Map } \\
\text { number } \\
\text { on } \\
\text { plate } 2\end{array}$} & \multicolumn{4}{|c|}{ Location } & \multirow{2}{*}{$\begin{array}{l}\text { Water } \\
\text { dis- } \\
\text { trict }\end{array}$} & \multirow{2}{*}{$\begin{array}{c}\text { Decree } \\
\text { (cubic } \\
\text { feet per } \\
\text { second) }\end{array}$} & \multirow[b]{2}{*}{ Source } & \multirow{2}{*}{$\begin{array}{l}\text { Capacity } \\
\text { (cubic } \\
\text { feet per } \\
\text { second) }\end{array}$} & \multirow{2}{*}{$\begin{array}{l}\text { Remarks, } \\
\text { irrigated } \\
\text { acreage }\end{array}$} \\
\hline & & $\begin{array}{l}\text { Sec- } \\
\text { tion }\end{array}$ & $\begin{array}{l}\text { Town- } \\
\text { ship }\end{array}$ & Range & $\begin{array}{l}\text { Prime } \\
\text { meridian }\end{array}$ & & & & & \\
\hline Abe Peterson----- & 1 & 03 & $23 s$ & $49 w$ & 6 & 67 & 6.30 & Arkansas River. & & \\
\hline 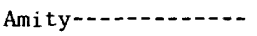 & 2 & 36 & $22 s$ & $48 w$ & 6 & 67 & 783.50 & Arkansas River-...- & 800.00 & 37,800 \\
\hline Arkansas-....... & 3 & 36 & $20 \mathrm{~s}$ & $64 w$ & 6 & 14 & 1.50 & & & \\
\hline $\begin{array}{l}\text { Baca Joint } \\
\quad \text { (Picketwire). }\end{array}$ & 4 & 13 & $33 \mathrm{~s}$ & $64 w$ & 6 & 19 & 101.19 & Purgatoire River--..- & 120 & 2,428 \\
\hline Baldwin-Stubbs---- & 5 & 18 & $22 s$ & $58 w$ & 6 & 17 & 22.00 & Arkansas River- & $0^{3}$ & 650 \\
\hline $\begin{array}{l}\text { Beaver Dam } \\
\quad \text { (Younger No.1). }\end{array}$ & 6 & 29 & $9 \mathrm{~s}$ & $80 w$ & 6 & 11 & 7.14 & Arkansas River--- & 6.00 & 320 \\
\hline 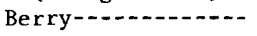 & 7 & 29 & $9 s$ & $80 w$ & 6 & 11 & 4.00 & Arkansas River & 8.00 & 200 \\
\hline Bessemer- & 8 & 36 & $20 s$ & $66 w$ & 6 & 14 & 392.65 & Arkansas River-..-- & 400.00 & 20,000 \\
\hline Booth Orchard-.-- & 9 & 5 & $21 \mathrm{~s}$ & $64 w$ & 6 & 14 & 30.30 & Arkansas River- & & $\begin{array}{l}\text { Water right sold to } \\
\text { City of Pueblo. }\end{array}$ \\
\hline Bray-Allen--...- & 10 & 22 & $14 \mathrm{~s}$ & $78 w$ & 6 & 11 & 11.00 & Arkansas River & 15.00 & 100 \\
\hline Brewer \& Kelso-... & 11 & 21 & $19 \mathrm{~s}$ & $68 w$ & 6 & 12 & 1.50 & Arkansas River. & & \\
\hline $\begin{array}{l}\text { Brush Hollow } \\
\text { Supply. }\end{array}$ & 12 & 16 & $18 \mathrm{~s}$ & $68 w$ & 6 & 12 & 22.83 & $\begin{array}{l}\text { Beaver Creek- } \\
\text { Brush Hollow }\end{array}$ & & Beaver Water Co. \\
\hline $\begin{array}{l}\text { Buena Vista } \\
\text { Smelting. }\end{array}$ & 13 & 09 & $14 \mathrm{~s}$ & $78 w$ & 6 & 11 & 115.00 & Arkansas River & & lnstream Use. \\
\hline Buffalo & 14 & 26 & $22 \mathrm{~s}$ & $44 w$ & 6 & 67 & 67.50 & Arkansas River-- & 80 & 5,000 \\
\hline Burns and Duncan-- & 15 & 12 & $32 \mathrm{~s}$ & $62 w$ & 6 & 19 & 6.00 & Purgatoire River---- & 6 & 322 \\
\hline "C" Ditch-........ & 16 & 1 & $33 \mathrm{~s}$ & $69 w$ & 6 & 19 & $\begin{array}{c}57.20 \\
(45.70 \\
\text { conditional })\end{array}$ & Whiskey Creek-.......... & & $\begin{array}{l}\text { Municipal supply } \\
\text { City of Trinidad. } \\
\text { with Canon-Oil }\end{array}$ \\
\hline Canon Mill-...... & 17 & 32 & $18 \mathrm{~s}$ & $70 \mathrm{w}$ & 6 & 12 & 153.00 & Arkansas River & & Creek. \\
\hline $\begin{array}{l}\text { Canon City - Oil } \\
\text { Creek. }\end{array}$ & 18 & 32 & $18 \mathrm{~s}$ & $70 w$ & 6 & 12 & 24.73 & Arkansas River- & 35.00 & 1,250 \\
\hline $\begin{array}{l}\text { Canon City Water } \\
\text { Works. }\end{array}$ & 19 & 31 & $18 \mathrm{~s}$ & $70 \mathrm{w}$ & 6 & 12 & 22.18 & Arkansas River- & 22.50 & $\begin{array}{l}\text { Canon City municipal } \\
\text { supply. }\end{array}$ \\
\hline Catlin-........... & 20 & 19 & $22 s$ & $58 w$ & 6 & 17 & 345.00 & Arkansas River & 345.00 & 18,800 \\
\hline Champ-- & 21 & 34 & $10 \mathrm{~s}$ & $80 w$ & 6 & 11 & 5.00 & Arkansas River-... & 7.00 & 320 \\
\hline Cherry Creek Ditch & 22 & 1 & $33 \mathrm{~s}$ & $69 w$ & 6 & 19 & 14.80 & Cherry Creek-1..... & & $\begin{array}{l}\text { Municipal supply, } \\
\text { City of Trinidad. }\end{array}$ \\
\hline Chililin........ & 23 & 7 & $33 \mathrm{~s}$ & $63 w$ & 6 & 19 & 7.00 & Purgatoire River-... & 10 & 114 \\
\hline Chilicott-n.......... & 24 & 25 & $15 \mathrm{~s}$ & $66 w$ & 6 & 10 & 78.58 & Fountain Creek-.... & 80 & 3,000 \\
\hline $\begin{array}{l}\text { Clayborn Extension } \\
\text { Cogan - Day }\end{array}$ & 26 & 23 & $14 \mathrm{~s}$ & $78 w$ & 6 & $\begin{array}{l}12 \\
11\end{array}$ & $\begin{array}{l}2.00 \\
3.00\end{array}$ & $\begin{array}{l}\text { Arkansas River. } \\
\text { Arkansas River-... }\end{array}$ & 30.00 & \\
\hline Collier---n. & 27 & 9 & $21 \mathrm{~s}$ & $62 w$ & 6 & 14 & 26.00 & Arkansas River-....- & 40.00 & 1,000 \\
\hline Colorado Canal-... & 28 & 10 & $21 \mathrm{~s}$ & $62 w$ & 6 & 14 & 756.28 & Arkansas River--... & 850.00 & 50,800 \\
\hline Col umbine-........ & 29 & 9 & $8 s$ & $79 w$ & 6 & 11 & & & & $\begin{array}{l}\text { Great Plains } \\
\text { system, } \\
\text { Transmountain } \\
\text { diversion. }\end{array}$ \\
\hline Crooked Ditch----- & 31 & & & & & 12 & 5.00 & $\begin{array}{l}\text { Arkansas River via } \\
\text { South Canon. }\end{array}$ & & \\
\hline DeWeese - Dye & 32 & 1 & $19 \mathrm{~s}$ & $71 w$ & 6 & 12 & 31.35 & Grape Creek-....... & 28 & 1,200 \\
\hline Derry No. 1 . & 33 & 16 & $10 \mathrm{~s}$ & $80 w$ & 6 & 11 & 4.00 & Arkansas River- & 4.00 & 400 \\
\hline Delappe $-\ldots$ & 34 & 21 & $9 \mathrm{~s}$ & $80 w$ & 6 & 11 & 5.00 & Arkansas River. & & \\
\hline
\end{tabular}


Table 4.--Major ditches in the area--Continued

\begin{tabular}{|c|c|c|c|c|c|c|c|c|c|c|}
\hline \multirow[b]{2}{*}{ Name $^{1}$} & \multirow{2}{*}{$\begin{array}{c}\text { Map } \\
\text { number } \\
\text { on } \\
\text { plate } 2\end{array}$} & \multicolumn{4}{|c|}{ Location } & \multirow{2}{*}{$\begin{array}{r}\text { Water } \\
\text { dis- } \\
\text { trict }\end{array}$} & \multirow{2}{*}{$\begin{array}{l}\text { Decree } \\
\text { (cubic } \\
\text { feet per } \\
\text { second) }\end{array}$} & \multirow[b]{2}{*}{ Source } & \multirow{2}{*}{$\begin{array}{l}\text { Capacity } \\
\text { (cubic } \\
\text { feet per } \\
\text { second) }\end{array}$} & \multirow{2}{*}{$\begin{array}{l}\text { Remarks, } \\
\text { irrigated } \\
\text { acreage }\end{array}$} \\
\hline & & $\begin{array}{l}\text { Sec- } \\
\text { tion }\end{array}$ & $\begin{array}{l}\text { Town- } \\
\text { ship }\end{array}$ & Range & $\begin{array}{l}\text { Prime } \\
\text { meridian }\end{array}$ & & & & & \\
\hline Dryfield-...-- & 35 & 34 & $12 \mathrm{~s}$ & $79 w$ & 6 & 11 & 6.20 & Arkansas River- & 8.00 & 40 \\
\hline Eckstine------- & 36 & 32 & $14 \mathrm{~s}$ & $78 w$ & 6 & 11 & 2.00 & Arkansas River. & & \\
\hline El Moro---ne-- & 37 & 32 & $32 \mathrm{~s}$ & $63 w$ & 6 & 19 & 2.48 & Purgatoire River-...- & 11 & 160 \\
\hline Enlarged South Side & 38 & 26 & $32 \mathrm{~s}$ & $63 w$ & 6 & 19 & & Purgatoire River- & 175 & 6,381 \\
\hline Escondito---- & 39 & 23 & $29 s$ & $62 w$ & 6 & 18 & & Apishapa River-- & 108 & \\
\hline Ewing & 40 & 11 & $8 \mathrm{~s}$ & $80 w$ & 6 & 11 & & & & $\begin{array}{l}\text { Transmountain } \\
\text { diversion. }\end{array}$ \\
\hline Excelsior-.....- & 41 & 36 & $20 s$ & $64 w$ & 6 & 14 & 60.00 & Arkansas River & 95.00 & 1,583 \\
\hline Farmer's Nepesta-- & & & & & & & & & & See Nepesta Farmer's \\
\hline Fort Lyon Storage- & 42 & 20 & $22 \mathrm{~s}$ & $20 w$ & 6 & 17 & & Arkansas River- & $1,500.00$ & $\begin{array}{l}\text { Deliver To Horse Creek } \\
\text { and Adobe Reservoir. }\end{array}$ \\
\hline Fort Bent-- & 43 & 1 & $23 s$ & $49 w$ & 6 & 67 & 216.81 & Arkansas River- & 250.00 & 6,840 \\
\hline Fort Lyon------ & 44 & 32 & $23 s$ & $55 w$ & 6 & 17 & 933.00 & Arkansas River & $1,500.00$ & 91,300 \\
\hline Fountain Mutual & 45 & 20 & $14 \mathrm{~s}$ & $66 w$ & 6 & 10 & 405.12 & Fountain Creek---- & 130 & 3,850 \\
\hline $\begin{array}{l}\text { Francisco and } \\
\text { Daigre. }\end{array}$ & 46 & 28 & $29 s$ & $68 w$ & 6 & 16 & & $\begin{array}{l}\text { Cucharas River } \\
\text { Wahatoya Creek- }\end{array}$ & & $\begin{array}{c}\text { Supplies Wahatoya and } \\
\text { Daigre Reservoir. }\end{array}$ \\
\hline Fremont County---- & 47 & 2 & $19 \mathrm{~s}$ & $70 w$ & 6 & 12 & 17.93 & Arkansas River & 28.00 & 425 \\
\hline Frontier- & 48 & 19 & $23 s$ & $41 w$ & 6 & & & & & $\begin{array}{l}\text { Considered a Kansas } \\
\text { water right. }\end{array}$ \\
\hline Garden Park------ & 49 & 9 & $17 \mathrm{~s}$ & $70 w$ & 6 & 12 & & Fourmile Creek. & & \\
\hline Gomez----n---- & 50 & 9 & $28 s$ & $66 w$ & 6 & 16 & 10.20 & Cucharas River- & 15 & 400 \\
\hline Grandview-..-... & 51 & 12 & & & & & & & & From Hydraulic \\
\hline Hamp-Bell-_....- & 52 & 36 & $20 \mathrm{~s}$ & $66 w$ & 6 & 14 & 2.92 & Arkansas River & 4.00 & 40 \\
\hline Hannenkratt------ & 53 & 7 & $19 \mathrm{~s}$ & $69 w$ & 6 & 12 & 5.16 & Arkansas River- & 6.00 & 125 \\
\hline Hardscrabble----- & 54 & 14 & $20 s$ & $69 w$ & 6 & 12 & .9375 & Hardscrabble Creek---- & & 75 \\
\hline Ha rmony------- & 55 & 16 & $14 \mathrm{~s}$ & $78 w$ & 6 & 11 & 8.00 & Arkansas River. & & \\
\hline Hayner-a-n & 56 & 21 & $19 \mathrm{~s}$ & $68 w$ & 6 & 12 & 0.60 & Arkansas River & 1.00 & 17 \\
\hline Helena-............... & 57 & 16 & $14 \mathrm{~s}$ & $78 w$ & 6 & 11 & 36.00 & Arkansas River- & 36.00 & 320 \\
\hline Hicklin--..-- & 58 & 27 & $24 \mathrm{~s}$ & $67 w$ & 6 & 15 & 1.80 & Greenhorn Creek. & & \\
\hline Highland--.--.-- & 59 & 1 & $25 \mathrm{~s}$ & $53 w$ & 6 & 17 & 62.60 & Purgatoire River & 60 & 2,975 \\
\hline Highline---.--- & 60 & 17 & $21 \mathrm{~s}$ & $61 \mathrm{w}$ & 6 & 14 & 501.60 & Arkansas River & 60.00 & 24,100 \\
\hline Hobson--......- & 61 & 1 & $20 \mathrm{~s}$ & $68 w$ & 6 & 12 & 6.00 & Arkansas River- & & $\begin{array}{l}\text { Transferred to City } \\
\text { of Pueblo. }\end{array}$ \\
\hline Hoehne--1-ne-n & 62 & 13 & $32 s$ & $63 w$ & 6 & 19 & 22.17 & Purgatoire River---- & 36 & 1,742 \\
\hline Holbrook--.----- & 63 & 34 & $22 s$ & $58 w$ & 6 & 17 & 600.00 & Arkansas River-.......... & 800.00 & 19,550 \\
\hline $\begin{array}{l}\text { Huerfano Valley } \\
\text { Ditch. }\end{array}$ & 64 & 32 & $23 \mathrm{~s}$ & $63 w$ & 6 & 14 & 42.00 & Huerfano River- & 170 & 1,000 \\
\hline Hyde------ & 65 & 29 & $22 \mathrm{~s}$ & $46 w$ & 6 & 67 & 23.44 & Arkansas River & 44.00 & $\begin{array}{c}970 \\
(1,000)\end{array}$ \\
\hline $\begin{array}{l}\text { Hydraulic and } \\
\text { Fruitland. }\end{array}$ & 66 & 6 & $19 \mathrm{~s}$ & $70 w$ & 6 & 12 & 77.00 & Arkansas River & 85.00 & 4,180 \\
\hline Ideal-a. & 67 & 20 & $19 \mathrm{~s}$ & $68 w$ & 6 & 12 & 20.05 & Arkansas River & 21.00 & $\begin{array}{c}\text { Industrial and domes- } \\
\text { tic supply - Ideal } \\
\text { Cement Corporation. }\end{array}$ \\
\hline
\end{tabular}


Table 4.--Major ditches in the area--Continued

\begin{tabular}{|c|c|c|c|c|c|c|c|c|c|c|}
\hline \multirow[b]{2}{*}{ Name $^{1}$} & \multirow{2}{*}{$\begin{array}{c}\text { Map } \\
\text { number } \\
\text { on } \\
\text { plate 2 }\end{array}$} & \multicolumn{4}{|c|}{ Location } & \multirow{2}{*}{$\begin{array}{l}\text { Water } \\
\text { dis- } \\
\text { trict }\end{array}$} & \multirow{2}{*}{$\begin{array}{l}\text { Decree } \\
\text { (cubic } \\
\text { feet per } \\
\text { second) }\end{array}$} & \multirow[b]{2}{*}{ Source } & \multirow{2}{*}{$\begin{array}{l}\text { Capacity } \\
\text { (cubic } \\
\text { feet per } \\
\text { second) }\end{array}$} & \multirow{2}{*}{$\begin{array}{l}\text { Remarks, } \\
\text { irrigated } \\
\text { acreage }\end{array}$} \\
\hline & & $\begin{array}{l}\text { Sec- } \\
\text { tion }\end{array}$ & $\begin{array}{l}\text { Town- } \\
\text { ship }\end{array}$ & Range & $\begin{array}{c}\text { Prime } \\
\text { meridian }\end{array}$ & & & & & \\
\hline Johns Flood-..-- & 68 & 22 & $32 \mathrm{~s}$ & $63 w$ & 6 & 19 & 123.63 & Purgatoire River-..- & 60 & 1,854 \\
\hline Jones-..-- & 69 & 9 & $23 \mathrm{~s}$ & $53 w$ & 6 & 17 & $(44.30)$ & $\begin{array}{c}\text { Arkansas River via Las } \\
\text { Animas Consolidated. }\end{array}$ & & $\begin{array}{l}\text { Lateral of Las Animas } \\
\text { Consolidated. }\end{array}$ \\
\hline Keesee--n.... & 70 & 1 & $23 \mathrm{~s}$ & $49 w$ & 6 & 67 & 28.50 & Arkansas River-.......... & 40.00 & 1,900 \\
\hline Kickingbird--.-- & 71 & & & & & & & & & Great Plains system \\
\hline Kraft-- & 72 & 26 & $5 \ln$ & $8 e$ & $\mathrm{~N}$ & 11 & 5.00 & Arkansas River- & 5.00 & 240 \\
\hline Lamar-_-....- & 73 & 25 & $22 \mathrm{~s}$ & $47 w$ & 6 & 67 & 297.45 & Arkansas River-- & 300.00 & 8,700 \\
\hline Langhoff-c. & 74 & 16 & $12 \mathrm{~s}$ & $79 w$ & 6 & 11 & 4.80 & Arkansas River & 5.00 & 80 \\
\hline Larkspur & 75 & 24 & $48 n$ & $6 \mathrm{e}$ & $\mathrm{N}$ & 11 & & & & Transmountain diversion \\
\hline $\begin{array}{l}\text { Las Animas } \\
\text { Consolidated. }\end{array}$ & 76 & 9 & $23 w$ & $53 w$ & 6 & 17 & 129.50 & Arkansas River- & 150.00 & 4,650 \\
\hline Las Animas Town-.- & 77 & 1 & $23 w$ & $53 w$ & 6 & 17 & & Arkansas River- & & $\begin{array}{l}\text { Water right transferred: } \\
\text { Las Animas Consolidated, } \\
\text { then Highline. }\end{array}$ \\
\hline $\begin{array}{l}\text { Las Animas } \\
\text { Extension. }\end{array}$ & 78 & 21 & $23 \mathrm{~s}$ & $52 w$ & 6 & 17 & 44.80 & $\begin{array}{l}\text { Arkansas via Las Animas } \\
\text { Consolidated. } \\
\text { Purgatoire River via } \\
\text { Highland. }\end{array}$ & 70.00 & 2,300 \\
\hline $\begin{array}{l}\text { Lester and } \\
\text { Atterbury }\end{array}$ & 79 & 13 & $19 \mathrm{~s}$ & $69 w$ & 6 & 12 & 9.10 & Arkansas River & 11.00 & 180 \\
\hline $\begin{array}{l}\text { Lewelling and } \\
\text { McCormick }\end{array}$ & 80 & 17 & $32 s$ & $61 w$ & 6 & 19 & 17.75 & Purgatoire River-... & 33 & 378 \\
\hline Manvel-....... & 81 & 32 & $22 \mathrm{~s}$ & $45 w$ & 6 & 67 & 54.00 & Arkansas River- & 60 & 750 \\
\hline Martin-- & 82 & 21 & $9 \mathrm{~s}$ & $80 w$ & 6 & 11 & 3.43 & Arkansas River & 4.00 & 240 \\
\hline Medano--..----- & 83 & 28 & $42 n$ & $13 e$ & $\mathbf{N}$ & 79 & 16.00 & Medano Creek-.............. & 15 & Transmountain diversion \\
\hline Minnequa Canal-... & 84 & 7 & $19 \mathrm{~s}$ & $69 w$ & 6 & 12 & 220.00 & Arkansas River & 286.00 & $\begin{array}{l}\text { Industrial supply, CF\&I } \\
\text { Steel Corporation. }\end{array}$ \\
\hline Mode1-......... & 85 & 33 & $32 \mathrm{~s}$ & $63 w$ & 6 & 19 & 200.00 & Purgatoire River-- & 700 & $6,177(20,000)$ \\
\hline $\begin{array}{l}\text { Monument Lake } \\
\text { Inlet. }\end{array}$ & 86 & 1 & $33 \mathrm{~s}$ & $69 w$ & 6 & 19 & & $\begin{array}{l}\text { Cherry Creek } \\
\text { Whiskey Creek- }\end{array}$ & & $\begin{array}{l}\text { Municipal supply, } \\
\text { City of Trinidad. }\end{array}$ \\
\hline $\begin{array}{l}\text { Monument Lake } \\
\text { Ditch No. } 1 \text {. }\end{array}$ & 87 & 24 & $32 w$ & $69 w$ & 6 & 19 & $\begin{array}{c}34.72 \\
(29.48 \\
\text { onditional) }\end{array}$ & $\begin{array}{l}\text { North Fork, Purgatoire } \\
\text { River. }\end{array}$ & & $\begin{array}{l}\text { Municipal supply, } \\
\text { City of Trinidad. }\end{array}$ \\
\hline $\begin{array}{l}\text { Monument Lake } \\
\text { Ditch No. } 2 \text {. }\end{array}$ & 88 & 25 & $32 \mathrm{~s}$ & $69 w$ & 6 & 19 & $\begin{array}{l}119 \\
(112 \\
\text { nditional) }\end{array}$ & Brown Creek & & $\begin{array}{l}\text { Municipal supply, } \\
\text { City of Trinidad. }\end{array}$ \\
\hline Nepesta Farmers--- & 89 & 15 & $23 \mathrm{~s}$ & $63 w$ & 6 & 14 & 175.00 & Huerfano River & 150 & 350 \\
\hline Ninemile............. & 90 & 7 & $27 \mathrm{~s}$ & $54 w$ & 6 & 17 & 18.00 & Purgatoire River & 85 & 1,805 \\
\hline North Lake Inlet-- & 91 & 24 & $32 \mathrm{~s}$ & $69 w$ & 6 & 19 & 65.77 & $\begin{array}{l}\text { North Fork, Purgatoire } \\
\text { River. }\end{array}$ & & $\begin{array}{l}\text { Municipal supply, } \\
\text { City of Trinidad. }\end{array}$ \\
\hline Orlando-............ & 92 & 26 & $26 s$ & $67 w$ & 6 & 79 & & Huerfano River- & & $\begin{array}{l}\text { Supplies Orlando } \\
\text { Reservoir. }\end{array}$ \\
\hline Otero-n.............. & 93 & 17 & $22 \mathrm{~s}$ & $59 w$ & 6 & 17 & 457.92 & Arkansas River- & 100.00 & 10,000 \\
\hline Owen and $\mathrm{Hall-..-}$ & 94 & & & & & 10 & 19.60 & Fountain Creek & 25 & 750 \\
\hline Oxford Farmers - - & 95 & 31 & $21 \mathrm{~s}$ & $60 w$ & 6 & 14 & 129.40 & Arkansas River & 130.00 & 6,000 \\
\hline $\begin{array}{l}\text { Park Center- } \\
\text { Pawnee- }\end{array}$ & $\begin{array}{l}96 \\
97\end{array}$ & 20 & $17 \mathrm{~s}$ & $70 \mathrm{w}$ & & 12 & & Fourmile Creek-- & & $\begin{array}{l}\text { Canon Heights Irriga- } \\
\text { tion, Great Plains } \\
\text { system. }\end{array}$ \\
\hline
\end{tabular}


Table 4.--Major ditches in the area--Continued

\begin{tabular}{|c|c|c|c|c|c|c|c|c|c|c|}
\hline Name $^{1}$ & $\begin{array}{c}\text { Map } \\
\text { number } \\
\text { on } \\
\text { plate } 2\end{array}$ & $\begin{array}{l}\text { Sec- } \\
\text { tion }\end{array}$ & 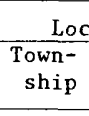 & $\frac{\text { cation }}{\text { Range }}$ & $\frac{}{\begin{array}{c}\text { Prime } \\
\text { meridian }\end{array}}$ & $\begin{array}{l}\text { Water } \\
\text { dis- } \\
\text { trict }\end{array}$ & $\begin{array}{c}\text { Decree } \\
\text { (cubic } \\
\text { feet per } \\
\text { second) }\end{array}$ & Source & $\begin{array}{l}\text { Capacity } \\
\text { (cubic } \\
\text { feet per } \\
\text { second) }\end{array}$ & $\begin{array}{l}\text { Remarks, } \\
\text { irrigated } \\
\text { acreage }\end{array}$ \\
\hline $\begin{array}{l}\text { Phelps } \\
\text { Picketwire- }\end{array}$ & $\begin{array}{r}98 \\
4\end{array}$ & 33 & $18 \mathrm{~s}$ & $70 \mathrm{w}$ & 6 & 12 & 1.00 & Arkansas River & & See Baca - Joint. \\
\hline Pickett............ & 99 & 13 & $49 n$ & $9 \mathbf{e}$ & $\mathrm{N}$ & 12 & 3.80 & Arkansas River- & 4.00 & 90 \\
\hline Pioneer--.-. & 100 & 34 & $10 \mathrm{~s}$ & $80 \mathrm{w}$ & 6 & 11 & 7.00 & Arkansas River & 10.00 & 320 \\
\hline Pleasant Valley-- & 101 & 27 & $49 n$ & $10 \mathrm{e}$ & $\mathrm{N}$ & 12 & 10.00 & Arkansas River- & 12.00 & 250 \\
\hline $\begin{array}{l}\text { Porter Woodruff } \\
\text { and Tells. }\end{array}$ & 102 & 21 & $19 \mathrm{~s}$ & $68 w$ & 6 & 12 & 3.86 & Arkansas River. & & \\
\hline Potter- & 103 & 25 & $22 s$ & $57 w$ & 6 & 17 & 13.00 & Arkansas River. & & \\
\hline Pueblo Waterworks- & 104 & 34 & $20 s$ & $65 w$ & 6 & 14 & 82.36 & Arkansas River & & $\begin{array}{l}\text { Pueblo municipal sup- } \\
\text { ply; includes Hobson } \\
\text { and Booth Orchard. }\end{array}$ \\
\hline Pump Ditch- & 105 & & & & 6 & 12 & 6.00 & $\begin{array}{l}\text { Arkansas River via South } \\
\text { Canon. }\end{array}$ & & \\
\hline Riverside Allen--- & 106 & 2 & $13 \mathrm{~s}$ & $79 w$ & 6 & 11 & 26.00 & Arkansas River & 30.00 & \\
\hline Riverside Dairy--- & 107 & 34 & $20 s$ & $65 w$ & 6 & 14 & 1.00 & Arkansas River- & 2.00 & 55 \\
\hline Rocky Ford--.... & 108 & 30 & $22 \mathrm{~s}$ & $57 w$ & 6 & 17 & 208.30 & Arkansas River & 150.00 & 8,200 \\
\hline Rogers-- & 109 & 17 & $48 n$ & $11 \mathrm{e}$ & $\mathrm{N}$ & 12 & 2.00 & Arkansas River & 2.00 & 40 \\
\hline $\begin{array}{l}\text { Saint Charles } \\
\text { Flood (Saint } \\
\text { Charles storm). }\end{array}$ & 110 & 15 & $23 \mathrm{~s}$ & $66 \mathrm{w}$ & 6 & 15 & & St. Charles River & 625.00 & $\begin{array}{l}\text { Industrial supply, } \\
\text { CF\&I Steel Corp. }\end{array}$ \\
\hline St. Charles Mesa-- & 111 & & & & & 14 & 3.80 & Bessemer Ditch & & Municipal supply \\
\hline Salas-- - & 112 & 1 & $33 \mathrm{~s}$ & $61 w$ & 6 & 19 & 8.79 & Purgatoire River- & 12 & 160 \\
\hline Salida-n........ & 113 & 2 & $50 n$ & $8 e$ & $\mathrm{~N}$ & 11 & 20.00 & Arkansas River- & 21.00 & 900 \\
\hline Salisbury-n-.- & 114 & 20 & $30 \mathrm{~s}$ & $63 w$ & 6 & 18 & & Apishapa River & & 600 \\
\hline Section House--- & 115 & 2 & $11 \mathrm{~s}$ & $80 w$ & 6 & 11 & 8.00 & Arkansas River. & & \\
\hline Sisson and Stubbs- & 116 & 14 & $23 s$ & $43 w$ & 6 & 67 & 32.74 & Arkansas River & $0^{3}$ & 300 \\
\hline South Side-- & 38 & & & & & 19 & 163.04 & Purgatoire River & 175 & See Enlarged Southside \\
\hline South Canon-...-- & 117 & 36 & $18 s$ & $71 \mathrm{w}$ & 6 & 12 & 34.51 & Arkansas River & 55.00 & 1,280 \\
\hline $\begin{array}{l}\text { Southern Colorado- } \\
\text { Power Co. }\end{array}$ & 118 & 31 & $18 \mathrm{~s}$ & $70 w$ & 6 & 12 & 61.00 & Arkansas River. & 60.00 & Cooling and steam. \\
\hline Stubbs and Miller- & 119 & & & & & 10 & 2.40 & Fountain Creek- & 15 & 360 \\
\hline Sunnyside Park--- & 120 & 2 & $50 n$ & $8 e$ & $\mathrm{~N}$ & 11 & 39.17 & Arkansas River & 20.00 & 700 \\
\hline Union Canal-..-- & 121 & 7 & $19 \mathrm{~s}$ & $69 w$ & 6 & 12 & 48.00 & $\begin{array}{l}\text { Arkansas via Minnequa } \\
\text { Canal. }\end{array}$ & 50.00 & 1,250 \\
\hline Upper River---- & 122 & 16 & $10 \mathrm{~s}$ & $80 w$ & 6 & 11 & 14.00 & Arkansas River- & 16.00 & 600 \\
\hline Victor Florez-- & 30 & & & & & & 4.00 & Purgatoire River & & See Enlarged Southside \\
\hline Walsenburg-- & 123 & 7 & $28 s$ & $66 w$ & 6 & 16 & 53.90 & Cucharas River. & 25 & 1,041 \\
\hline Wells and Starr--- & 124 & 29 & $9 \mathrm{~s}$ & $80 w$ & 6 & 11 & 8.00 & Arkansas River & & \\
\hline Welton- - & 125 & 29 & $22 s$ & $62 w$ & 6 & 14 & 150.20 & Huerfano River- & 125 & 1,500 \\
\hline West Pueblo-n- & 126 & 31 & $20 s$ & $65 w$ & 6 & 14 & 17.80 & Arkansas River- & 10.00 & 500 \\
\hline Wheel-- & 127 & 34 & $10 \mathrm{~s}$ & $80 w$ & 6 & 11 & 16.00 & Arkansas River & 10.00 & 200 \\
\hline Widderfield----- & 128 & 15 & $30 s$ & $63 w$ & 6 & 11 & & Apishapa River- & & 200 \\
\hline William - Hamm---- & 129 & 15 & $50 \mathrm{n}$ & $8 \mathrm{e}$ & $\mathrm{N}$ & 11 & 17.00 & Arkansas River- & 17.00 & 534 \\
\hline Wurtz- - - & 130 & 17 & $8 \mathrm{~s}$ & $80 w$ & 6 & 11 & & & & Transmountain diversion \\
\hline$X-Y$ and Graham--- & 131 & 25 & $22 \mathrm{~s}$ & $45 w$ & 6 & 67 & $\begin{array}{l}69.00(\mathrm{X}-\mathrm{Y}) \\
61.00(\text { Graham })\end{array}$ & Arkansas River & 80 & 6,000 \\
\hline Younger No. 1 - & 6 & & & & & & & & & See Beaver Dam \\
\hline Younger No. 2--.- & 132 & 32 & $9 s$ & $80 w$ & 6 & 11 & 6.29 & Arkansas River- & 8.00 & 340 \\
\hline
\end{tabular}

${ }^{1}$ Alternate name in parentheses.

${ }^{2}$ Irrigated acreages were gathered from a number of sources. They are meant to give only an indication of the relative size of the ditch.

${ }^{3} 0$ indicates ditch has no headgate; served by well or pump. 
Table 5.--Reservoirs in the area

\begin{tabular}{|c|c|c|c|c|c|c|c|c|c|}
\hline \multirow{2}{*}{ Name } & \multirow{2}{*}{$\begin{array}{l}\text { Map } \\
\text { number } \\
\text { on } \\
\text { plate } 2\end{array}$} & \multicolumn{4}{|c|}{ Dam location } & \multicolumn{2}{|c|}{ Stream } & \multirow{2}{*}{$\begin{array}{c}\text { Total } \\
\text { capacity } \\
\text { (cubic } \\
\text { feet per } \\
\text { second) }\end{array}$} & \multirow{2}{*}{ Operator } \\
\hline & & $\begin{array}{l}\text { Sec- } \\
\text { tion }\end{array}$ & $\begin{array}{l}\text { Town- } \\
\text { ship }\end{array}$ & Range & $\begin{array}{l}\text { Prime } \\
\text { meridian }\end{array}$ & Location & Source & & \\
\hline Adobe (Blue) & 1 & 7 & $21 \mathrm{~s}$ & $52 w$ & 6 & Adobe Creek & $\begin{array}{l}\text { Arkansas River } \\
\text { Adobe Creek }\end{array}$ & 85,000 & Fort Lyon Canal \\
\hline Antonio D. Valdez--- & 2 & \multicolumn{3}{|c|}{-see Saliba } & & & & & \\
\hline Arnold Flood- & 3 & 17 & $30 \mathrm{~s}$ & $66 w$ & 6 & Off channel & $\begin{array}{l}\text { South Fork } \\
\text { Santa Clara Creek }\end{array}$ & 96 & \\
\hline Beckwith (Hayden) $\cdots$ & 4 & 23 & $24 s$ & $67 w$ & 6 & Off channel & Greenhorn Creek & 763 & $\begin{array}{l}\text { Colorado City } \\
\text { Development Company. }\end{array}$ \\
\hline $\begin{array}{l}\text { Big Johnson (Fountain } \\
\text { Valley No. 2) }\end{array}$ & 5 & 17 & $15 s$ & $65 w$ & 6 & Off channel & Fountain Creek & 3,950 & Fountain Mutual ditch \\
\hline $\begin{array}{l}\text { Big Tooth (Reservoir } \\
\text { No. 1). }\end{array}$ & 6 & 14 & $14 \mathrm{~s}$ & $68 w$ & 6 & $\begin{array}{l}\text { South Ruxton } \\
\text { Willow Creek }\end{array}$ & $\begin{array}{l}\text { South Ruxton } \\
\text { Willow Creek } \\
\text { Lake Moraine }\end{array}$ & 645 & Colorado Springs \\
\hline $\begin{array}{l}\text { Bighorn (Reservoir } \\
\text { No. 7). }\end{array}$ & 7 & 24 & $14 \mathrm{~s}$ & $69 w$ & 6 & $\begin{array}{l}\text { East Fork West } \\
\text { Beaver Creek. }\end{array}$ & $\begin{array}{l}\text { East Fork West } \\
\text { Beaver Creek. }\end{array}$ & 191 & Colorado Springs \\
\hline Bison- & 8 & 2 & $15 s$ & $69 w$ & 6 & Bison Creek & Bison Creek & 1,148 & Victor \\
\hline Black Hills & 9 & & & & & & & & \\
\hline Bluen-mon & 1 & \multirow{2}{*}{\multicolumn{3}{|c|}{$\begin{array}{l}\text { - see Adobe } \\
\text {-see Meredith }\end{array}$}} & & & & & \\
\hline Bob Creek- & 10 & & & & & & & & \\
\hline $\begin{array}{l}\text { Boehmer (Reservoir } \\
\text { No. 2). }\end{array}$ & 11 & 30 & $14 \mathrm{~s}$ & $68 w$ & 6 & Boehmer Creek & $\begin{array}{l}\text { Boehmer Creek } \\
\text { Strictler Tunnel }\end{array}$ & 541 & Colorado Springs \\
\hline $\begin{array}{l}\text { Bradford (Orlando } \\
\text { Reservoir No. 1). }\end{array}$ & 12 & 36 & $26 s$ & $66 w$ & 6 & off channel & Huerfano River & 4,350 & \\
\hline Brown No. 1 & 13 & 25 & $30 s$ & $61 w$ & 6 & off channel & Van Bremer Arroyo & 180 & \\
\hline Brush Hollow- & 14 & 30 & $18 \mathrm{~s}$ & $68 w$ & 6 & Brush Hollow & Beaver Creek & 4,125 & Beaver Park Irrigation \\
\hline CF\&I Reservoir No. 1- & 15 & \multicolumn{3}{|c|}{-see Minnequa } & & & & & \\
\hline $\begin{array}{l}\text { CF\&I Reservoir No. } 2--- \\
\text { (Saint Charles No. } 2 \text { ) }\end{array}$ & 16 & 35 & $21 \mathrm{~s}$ & $65 w$ & 6 & Salt Creek & $\begin{array}{l}\text { Arkansas River } \\
\text { Saint Charles }\end{array}$ & 2,700 & $\begin{array}{l}\text { CF\&I Steel } \\
\text { Corporation. }\end{array}$ \\
\hline $\begin{array}{l}\text { CF\&I Reservoir No. } 3 \cdots \\
\text { (Saint Charles No. } 3 \text { ) }\end{array}$ & 17 & 3 & $22 s$ & $65 \omega$ & 6 & Salt Creek & $\begin{array}{l}\text { Arkansas River } \\
\text { Saint Charles }\end{array}$ & 8,638 & $\begin{array}{l}\text { CF\&I Steel } \\
\text { Corporation. }\end{array}$ \\
\hline Callahan-........... & 18 & 27 & $16 s$ & $65 \omega$ & 6 & off channel & Fountain Creek & 347 & Chilicott Ditch \\
\hline Cheraw- & 19 & 36 & $22 \mathrm{~s}$ & $55 w$ & 6 & Off channel & $\begin{array}{l}\text { Holbrook Canal } \\
\text { drainage. }\end{array}$ & & Holbrook Canal \\
\hline Chicoas No, 5 & 20 & \multicolumn{4}{|c|}{-see Nepesta Reservoir No. 5} & & & & \\
\hline Clark No. 1- & 21 & 30 & $25 s$ & 66w & 6 & Off channel & Apache Creek & 220 & \\
\hline Clark No. 2- & 22 & $20^{\circ}$ & $25 \mathrm{~s}$ & $66 w$ & 6 & Hill Arroyo & Hill Arroyo & 593 & \\
\hline Clear Creek- & 23 & 8 & $8 s$ & $79 w$ & 6 & Clear Creek & $\begin{array}{l}\text { Clear Creek and } \\
\text { transmountain } \\
\text { import by exchange }\end{array}$ & 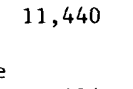 & $\begin{array}{l}\text { Pueblo Board of Water } \\
\text { Works }\end{array}$ \\
\hline Craeger & 24 & 28 & $25 s$ & $71 w$ & 6 & Off channel & $\begin{array}{l}\text { Muddy Creek } \\
\text { Medano Ditch }\end{array}$ & 484 & \\
\hline Crane - Holmes No. 1--- & 25 & 35 & $26 s$ & $66 w$ & 6 & off channel & Jones Arroyo & 386 & \\
\hline Crane - Holmes No. 2--- & 26 & 35 & $26 s$ & $66 w$ & 6 & Off channel & Jones Arroyo & 1,000 & \\
\hline Cripple Creek No. 2--- & 27 & 24 & $14 \mathrm{~s}$ & $69 w$ & 6 & $\begin{array}{l}\text { West fork of } \\
\text { West Beaver } \\
\text { Creek. }\end{array}$ & $\begin{array}{l}\text { West Fork of } \\
\text { West Beaver Creek. }\end{array}$ & 280 & Cripple Creek \\
\hline Cripple Creek No. $3---$ & 28 & 34 & $14 \mathrm{~s}$ & $69 w$ & 6 & $\begin{array}{l}\text { West Fork of } \\
\text { West Beaver } \\
\text { Creek. }\end{array}$ & $\begin{array}{l}\text { West fork of } \\
\text { West Beaver Creek. }\end{array}$ & 85 & Cripple Creek \\
\hline Cucharas-- & 29 & 36 & $26 s$ & $65 w$ & 6 & Cucharas River & Cucharas River & 40,960 & $\begin{array}{l}\text { Huerfano - Cucharas } \\
\text { Irrigation Company. }\end{array}$ \\
\hline Crystal Creek- & 30 & 17 & $13 \mathrm{~s}$ & $68 w$ & 6 & Crystal Creek & Crystal Creek & 3,480 & Colorado Springs \\
\hline Daigre-n- & 31 & 22 & $29 s$ & $68 w$ & 6 & Off channel & Cucharas & 139 & Walsenburg \\
\hline DeWeese - Dye-.... & 32 & 20 & $21 \mathrm{~s}$ & $72 w$ & 6 & Grape Creek & Grape Creek & 1,772 & $\begin{array}{l}\text { DeWeese - Dye Irriga- } \\
\text { tion Company. }\end{array}$ \\
\hline Dingwall-... & 33 & 28 & $22 \mathrm{~s}$ & $49 w$ & 6 & & Fort Lyon drainage & 461 & \\
\hline Dotson- & 34 & 14 & $22 s$ & $61 w$ & 6 & off channel & $\begin{array}{l}\text { Nepesta Ditch } \\
\text { Chicosa Creek } \\
\text { Huerfano River }\end{array}$ & 2,500 & $\begin{array}{l}\text { Nepesta Farmer's } \\
\text { Ditch. }\end{array}$ \\
\hline
\end{tabular}


Table 5.--Reservoirs in the area--Continued

\begin{tabular}{|c|c|c|c|c|c|c|c|c|c|}
\hline \multirow[b]{2}{*}{ Name } & \multirow{2}{*}{$\begin{array}{c}\text { Map } \\
\text { number } \\
\text { on } \\
\text { plate } 2\end{array}$} & \multicolumn{4}{|c|}{ Dam location } & \multicolumn{2}{|c|}{ Stream } & \multirow{2}{*}{$\begin{array}{c}\text { Total } \\
\text { capacity } \\
\text { (cubic } \\
\text { feet per } \\
\text { second) }\end{array}$} & \multirow[b]{2}{*}{ Operator } \\
\hline & & $\begin{array}{l}\text { Sec- } \\
\text { tion }\end{array}$ & $\begin{array}{l}\text { Town- } \\
\text { ship }\end{array}$ & Range & $\begin{array}{l}\text { Prime } \\
\text { meridian }\end{array}$ & Location & Source & & \\
\hline 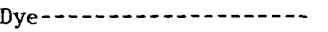 & 35 & 5 & $23 s$ & $56 w$ & 6 & Off channel & Arkansas River & 7,986 & Holbrook Canal \\
\hline Fisher Canyon- & 36 & 12 & $15 \mathrm{~s}$ & $67 \omega$ & 6 & Fisher Canyon & Rosemont Reservoir & 63 & Colorado Springs \\
\hline Fort Lyon Canal-_... & 37 & 23 & $21 \mathrm{~s}$ & $46 w$ & 6 & Off channel & Fort Lyon tailwater & 644 & Fort Lyon Canal Company \\
\hline Fountain Valley No. 2-- & 5 & \multicolumn{4}{|c|}{-see Big Johnson } & & & & \\
\hline Fountain Valley No. $3--$ & 38 & \multicolumn{4}{|c|}{-see Little Johnson } & & & & \\
\hline Gold Camp- & 39 & 34 & $14 \mathrm{~s}$ & $67 w$ & 6 & Off channel & $\begin{array}{l}\text { North and South } \\
\text { Cheyenne Creeks. }\end{array}$ & 380 & Colorado Springs \\
\hline Great Plains- & 40 & & $\begin{array}{l}20 s \\
20 s\end{array}$ & $\begin{array}{l}47 w \\
48 w\end{array}$ & $\begin{array}{l}8 \\
6\end{array}$ & Off channel & Arkansas River & 265,552 & Amity Canal \\
\hline Grizzly ${ }^{2} \ldots$ & 41 & & & & & Lincoln Gulch & $\begin{array}{l}\text { Roaring Fork } \\
\text { Lost Man } \\
\text { New York Gulch } \\
\text { Lincoln Gulch } \\
\text { Tabor Gulch }\end{array}$ & & Twin Lakes Company \\
\hline Hayden-- & 4 & \multicolumn{3}{|c|}{-see Beckwith } & & & & & \\
\hline Henry-- & 42 & 5 & $21 \mathrm{~s}$ & $56 w$ & 6 & Off channel & Arkansas River & 11,914 & Colorado Coral \\
\hline Hermosa Valley- & 43 & 5 & $34 \mathrm{~s}$ & $61 w$ & 6 & Off channel & $\begin{array}{l}\text { San Francisco } \\
\text { Creek. }\end{array}$ & 1,000 & \\
\hline Holbrook---nes & 44 & 7 & $23 s$ & $55 w$ & 6 & off channel & Arkansas River & 7,472 & Holbrook Canal \\
\hline Holita-n- & 45 & 35 & $27 \mathrm{~s}$ & $66 w$ & 6 & Off channel & Cucharas River & 400 & \\
\hline Homestake ${ }^{2}-\ldots$ & 46 & & & & & Homes take Creek & $\begin{array}{l}\text { Homestake Creek } \\
\text { East Fork } \\
\text { Missouri Tunnel }\end{array}$ & 43,300 & Homestake Project \\
\hline Horse Creek (Timber) - & 47 & 12 & $22 \mathrm{~s}$ & $54 w$ & 6 & Horse Creek & $\begin{array}{l}\text { Arkansas River } \\
\text { Horse Creek }\end{array}$ & 28,000 & Fort Lyon Canal \\
\hline Horseshoe- & 48 & \multicolumn{3}{|c|}{-see Miriam } & & & & & \\
\hline Huerfano Valley- & 49 & 12 & $22 \mathrm{~s}$ & $63 w$ & 6 & Off channel & Huerfano River & 2,088 & $\begin{array}{l}\text { Huerfano Valley } \\
\text { ditch. }\end{array}$ \\
\hline Is abel-nes & 50 & 6 & $24 s$ & $68 w$ & 6 & $\begin{array}{l}\text { Saint Charles } \\
\text { River. }\end{array}$ & $\begin{array}{l}\text { Saint Charles } \\
\text { River. }\end{array}$ & 760 & U.S. Forest Service \\
\hline Ivanhoe-1-- & 51 & & & & & Ivanhoe Creek & Ivanhoe Creek & & Busk - Ivanhoe \\
\hline 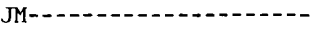 & 52 & 32 & $25 s$ & $71 w$ & 6 & Off channel & Greaser Creek & 200 & \\
\hline John Martinn & 53 & 8 & $23 s$ & $49 w$ & 6 & Arkansas River & Arkansas River & $\begin{array}{l}701,775 \\
\text { (initial) }\end{array}$ & $\begin{array}{l}\text { U.S. Army Corps } \\
\text { of Engineers. }\end{array}$ \\
\hline Johns-- & 54 & 10 & $32 \mathrm{~s}$ & $63 w$ & 6 & Off channel & Purgatoire River & 395 & \\
\hline 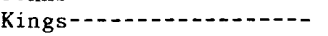 & $40 e$ & \multicolumn{4}{|c|}{ - see Great Plains } & & & & \\
\hline La Joya-............. & 55 & 10 & $28 \mathrm{~s}$ & $66 w$ & 6 & Off channel & Cucharas River & 177 & \\
\hline La Veta Town- & 56 & 28 & $29 s$ & $68 w$ & 6 & off channel & Cucharas Creek & 256 & La Veta \\
\hline Lake Moraine-- & 57 & 21 & $14 \mathrm{~s}$ & $68 w$ & 6 & Ruxton Creek & $\begin{array}{l}\text { Ruxton Creek } \\
\text { St. John Tunnel }\end{array}$ & 800 & Colorado Springs \\
\hline $\begin{array}{l}\text { Little Johnson- } \\
\text { (Fountain Valley No.3) }\end{array}$ & 38 & 2 & $15 s$ & $66 w$ & 6 & Off channel & Fountain Creek & 682 & Fountain Mutual ditch \\
\hline Maria - Stevens-- & 58 & 28 & $27 \mathrm{~s}$ & $65 w$ & 6 & Off channel & Cucharas River & 2,300 & \\
\hline Martin- & 59 & \multicolumn{3}{|c|}{ - see 0ehm } & & & & & \\
\hline Mason (Reservoir No.4)- & 60 & 5 & $15 \mathrm{~s}$ & $68 w$ & 6 & $\begin{array}{l}\text { Middle Beaver } \\
\text { Creek. }\end{array}$ & $\begin{array}{l}\text { Middle Beaver Creek } \\
\text { Strictler Tunnel }\end{array}$ & 1,966 & Colorado Springs \\
\hline McKinley- & 61 & 22 & $25 s$ & $71 w$ & 6 & Off channel & Muddy Creek & 136 & \\
\hline $\begin{array}{l}\text { McReynolds (Reservoir } \\
\text { No.5) }\end{array}$ & 62 & 4 & $15 \mathrm{~s}$ & $68 w$ & 6 & $\begin{array}{l}\text { Middle Beaver } \\
\text { Creek. }\end{array}$ & $\begin{array}{l}\text { Middle Beaver } \\
\text { Creek. }\end{array}$ & 2,050 & Colorado Springs \\
\hline Meredith (Bob Creek)--- & 10 & 36 & $21 \mathrm{~s}$ & $57 w$ & 6 & Bob Creek & Arkansas River & 26,028 & Colorado Coral \\
\hline $\begin{array}{l}\text { Minnequa (CF\&I Reservoir } \\
\text { No.1). }\end{array}$ & 15 & 11 & $21 \mathrm{~s}$ & $65 w$ & 6 & Off channel & $\begin{array}{l}\text { Arkansas River } \\
\text { Saint Charles }\end{array}$ & 1,380 & $\begin{array}{l}\text { CF\&I Steel } \\
\text { Corporation. }\end{array}$ \\
\hline Miriam (Horseshoe)---- & 48 & 13 & $28 \mathrm{~s}$ & $67 w$ & 6 & Off channel & Cucharas & 2,760 & Walsenburg \\
\hline 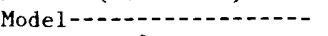 & 9 & 19 & $31 \mathrm{~s}$ & $62 w$ & 6 & Of $f$ channel & Purgatoire River & 20,000 & See text \\
\hline Montgomery ${ }^{2}-\ldots$ & 63 & 14 & $8 \mathrm{~s}$ & $78 w$ & 6 & $\begin{array}{l}\text { Middle Fork } \\
\text { South Platte }\end{array}$ & $\begin{array}{l}\text { Middle Fork } \\
\text { Hoosier Tunnel }\end{array}$ & 5,100 & $\begin{array}{l}\text { Blue River Projects } \\
\text { Colorado Springs }\end{array}$ \\
\hline
\end{tabular}


Table 5.--Reservoirs in the area--Continued

\begin{tabular}{|c|c|c|c|c|c|c|c|c|c|}
\hline \multirow{2}{*}{ Name } & \multirow{2}{*}{$\begin{array}{c}\text { Map } \\
\text { number } \\
\text { on } \\
\text { plate } 2\end{array}$} & \multicolumn{4}{|c|}{ Dam location } & \multicolumn{2}{|c|}{ Stream } & \multirow{2}{*}{$\begin{array}{c}\text { Total } \\
\text { capacity } \\
\text { (cubic } \\
\text { feet per } \\
\text { second) } \\
\end{array}$} & \multirow{2}{*}{ Operator } \\
\hline & & $\begin{array}{l}\text { Sec- } \\
\text { tion }\end{array}$ & $\begin{array}{l}\text { Town- } \\
\text { ship }\end{array}$ & Range & $\begin{array}{l}\text { Prime } \\
\text { meridian }\end{array}$ & Location & Source & & \\
\hline Monument-- & 64 & 31 & $32 \mathrm{~s}$ & $68 w$ & 6 & Off channel & $\begin{array}{l}\text { North Fork } \\
\text { Purgatoire } \\
\text { Brown Creek } \\
\text { Cherry Creek } \\
\text { Whiskey Creek }\end{array}$ & 1,430 & Trinidad \\
\hline Mosca (Smith) & 65 & 31 & $26 s$ & $71 \mathrm{w}$ & 6 & Off channel & Poison Canon & 96 & \\
\hline Mount Elbert forebay--- & 66 & 8 & $11 \mathrm{~s}$ & $80 w$ & 6 & Off channel & $\begin{array}{l}\text { Mount Elbert } \\
\text { conduit. }\end{array}$ & 11,530 & $\begin{array}{l}\text { U.S. Bureau of } \\
\text { Reclamation. }\end{array}$ \\
\hline Mount Pisgah (Wright's) & 67 & 31 & $14 \mathrm{~s}$ & $70 w$ & 6 & Fourmile Creek & Fourmile Creek & 2,471 & $\begin{array}{l}\text { Catlin Canal Company } \\
\text { and Garden Park. }\end{array}$ \\
\hline Murray----- & 68 & 21 & $25 s$ & $71 w$ & 6 & off channel & Muddy Creek & 180 & \\
\hline Nee Gronda (Big Water)- & $40 a$ & & & & & \\
\hline Nee So Pa (Black Water) & $40 \mathrm{~b}$ & \multicolumn{2}{|c|}{$\begin{array}{l}\text {-see Great Plains } \\
\text {-see Great Plains }\end{array}$} & & & & & & \\
\hline $\begin{array}{l}\text { Nee So She (Standing } \\
\text { Water). }\end{array}$ & $40 c$ & $-\mathrm{se}$ & ee Grea & at Plair & ins & & & & \\
\hline Nee Skah (Queens) - - - & $40 \mathrm{~d}$ & \multicolumn{4}{|c|}{-see Great Plains } & & & & \\
\hline $\begin{array}{l}\text { Nepesta Reservoir No. } 5 \\
\quad(\text { Chicosa No.5). }\end{array}$ & 20 & 32 & $22 \mathrm{~s}$ & $61 w$ & 6 & Chicosa Creek & \multicolumn{2}{|l|}{$\begin{array}{l}\text { Nepesta Farmer's } \\
\text { Ditch, and Huerfano } \\
\text { River. }\end{array}$} & $\begin{array}{l}\text { Nepesta Farmer's } \\
\text { Ditch. }\end{array}$ \\
\hline $\begin{array}{l}\text { Nichols (Reservoir } \\
\text { No.4). }\end{array}$ & 69 & 25 & $12 \mathrm{~s}$ & $68 w$ & 6 & $\begin{array}{l}\text { West Monument } \\
\text { Creek. }\end{array}$ & \multicolumn{2}{|c|}{$\begin{array}{l}\text { West Monument Creek } 586 \\
\text { Rampart Range } \\
\text { Tunnel No.1. }\end{array}$} & Colorado Springs \\
\hline North Catamount------ & 70 & 12 & $13 \mathrm{~s}$ & $69 w$ & 6 & $\begin{array}{l}\text { North Catamount } \\
\text { Creek. }\end{array}$ & $\begin{array}{l}\text { North Catamount } \\
\text { Creek. } \\
\text { Montgomery pipelin }\end{array}$ & 12,035 & Colorado Springs \\
\hline $\begin{array}{l}\text { Northfield (Reservoir } \\
\text { No.1). }\end{array}$ & 71 & 25 & $12 \mathrm{~s}$ & $68 w$ & 6 & $\begin{array}{l}\text { West Monument } \\
\text { Creek. }\end{array}$ & \multicolumn{2}{|c|}{$\begin{array}{l}\text { Montgomery pipeline } \\
\text { West Monument Creek } 276\end{array}$} & Colorado Springs \\
\hline 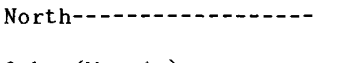 & 72 & 19 & $32 s$ & $68 w$ & 6 & off channel & \multirow[t]{2}{*}{$\begin{array}{l}\text { North Fork } \\
\text { Purgatoire. }\end{array}$} & 4,315 & Trinidad \\
\hline Oehm (Martin) & 59 & 13 & $28 \mathrm{~s}$ & $67 w$ & 6 & off channel & & 4,880 & Walsenburg \\
\hline Orlando (Reservoir No.1) & 12 & \multicolumn{3}{|c|}{-see Bradford } & & & & & , \\
\hline Orlando (Reservoir No.2) & 73 & 20 & $26 s$ & 66w & 6 & Off channel & $\begin{array}{l}\text { Greasewoud Arroyo } \\
\text { Huerfano River }\end{array}$ & 3,000 & . \\
\hline Penrose-Rosemont------ & 74 & \multicolumn{4}{|c|}{-see Rosemont } & & & & \\
\hline Penrose Reservoir----- & 75 & 1 & $15 s$ & $67 w$ & 6 & Off channel & \multicolumn{2}{|c|}{ Rosemont Reservoir 8} & Colorado Springs \\
\hline Pueblo- & 76 & 36 & $20 s$ & $66 w$ & 6 & Arkansas River & $\begin{array}{l}\text { Arkansas River } \\
\text { transport and } \\
\text { diversion. }\end{array}$ & $\begin{array}{l}357,000 \\
\text { (initial) }\end{array}$ & $\begin{array}{l}\text { U.S. Bureau of } \\
\text { RecIamation. }\end{array}$ \\
\hline Queens--1- & $40 \mathrm{~d}$ & \multirow{2}{*}{\multicolumn{3}{|c|}{$\begin{array}{l}\text {-see Great Plains } \\
26 \quad 12 \mathrm{~s} 68 \mathrm{w}\end{array}$}} & ins (Nee & Skah) & & & \\
\hline $\begin{array}{l}\text { Rampart (Reservoir } \\
\text { No.5) }\end{array}$ & 77 & & & & 6 & $\begin{array}{l}\text { West Monument } \\
\text { Creek. }\end{array}$ & $\begin{array}{l}\text { West Monument } \\
\text { Creek, Rampart } \\
\text { Range Tunnel } \\
\text { No. } 1 \text {. }\end{array}$ & 40,886 & Colorado Springs \\
\hline Reservoir No. $7 \ldots$ & 7 & \multicolumn{4}{|c|}{-see Bighorn } & & & & \\
\hline Reservoir No. $8 \ldots$ & 97 & \multicolumn{4}{|c|}{-see Wilson } & & & & \\
\hline Reservoir No. 2-- & 11 & \multicolumn{4}{|c|}{-see Boehmer } & & & & \\
\hline Reservoir No. 4 & 60 & \multicolumn{4}{|c|}{-see Mason } & & & & \\
\hline Reservoir No. 5 & 62 & \multicolumn{4}{|c|}{-see McReynolds } & & & & \\
\hline Reservoir No. 1-- & 6 & \multicolumn{4}{|c|}{-see Big Tooth } & & & & \\
\hline Reservoir No. 1- & 71 & \multicolumn{4}{|c|}{-see Northfield } & & & & \\
\hline Reservoir No. 4---1-- & 69 & \multicolumn{4}{|c|}{ - see Nichols } & & & & \\
\hline Reservoir No. 5-- & 77 & \multicolumn{3}{|c|}{-see Rampart } & & & & & \\
\hline Reservoir No. 2 & 87 & $-\mathrm{se}$ & ee Stan & nley $\mathrm{Ca}$ & anyon & & & & \\
\hline Roach-- & 78 & 32 & $25 s$ & $71 w$ & 6 & off channeI & $\begin{array}{l}\text { Muddy Creek } \\
\text { Medano Ditch }\end{array}$ & 200 & \\
\hline
\end{tabular}


Table 5.--Reservoirs in the area--Continued

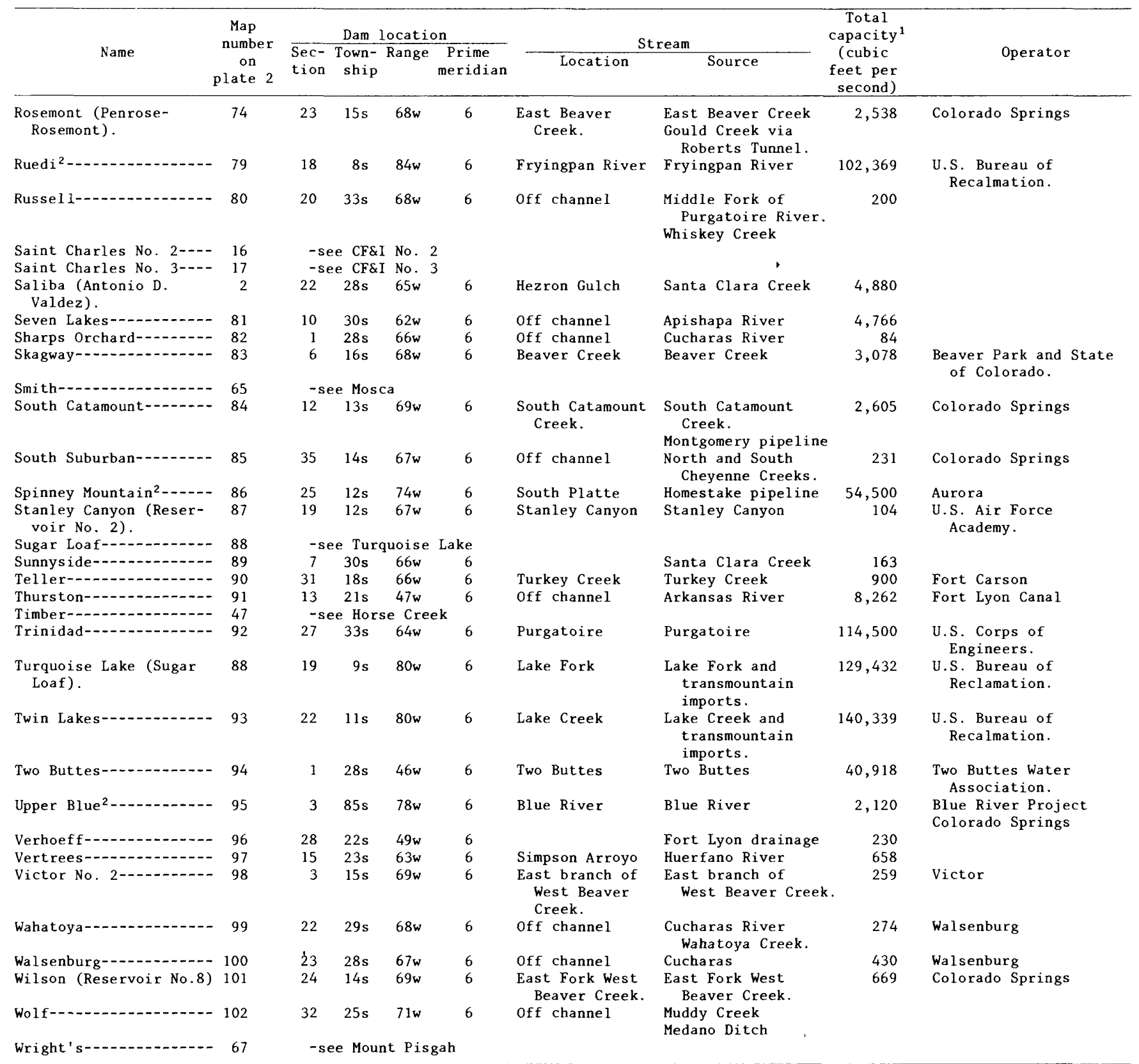

${ }^{1}$ Reservoir capacities were gathered from a number of sources and are meant only to give an indication of relative size. ${ }^{2}$ Reservoir located outside the Arkansas River basin. 